Portland State University

PDXScholar

$11-4-1993$

\title{
The Public Persona of Nelson R. Mandela: A Study of U.S. Print Media Narratives
}

Molly Jeane McVey

Portland State University

Follow this and additional works at: https://pdxscholar.library.pdx.edu/open_access_etds

Part of the Speech and Rhetorical Studies Commons

Let us know how access to this document benefits you.

\section{Recommended Citation}

McVey, Molly Jeane, "The Public Persona of Nelson R. Mandela: A Study of U.S. Print Media Narratives" (1993). Dissertations and Theses. Paper 4692.

https://doi.org/10.15760/etd.6576

This Thesis is brought to you for free and open access. It has been accepted for inclusion in Dissertations and Theses by an authorized administrator of PDXScholar. Please contact us if we can make this document more accessible: pdxscholar@pdx.edu. 
AN ABSTRACT OF THE THESIS OF MOIly Jeanne MCVey for the Master of Science in Speech Communication presented November 4, 1993.

Title: The Public Persona of Nelson R. Mandela: A Study of U.S. Print Media Narratives

APPROVED BY THE MEMBERS OF THE THESIS COMMITTEE:

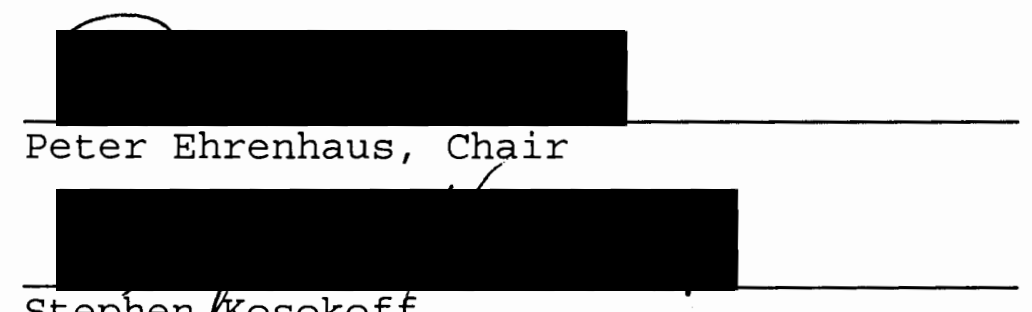
Stephen /Kosokof王

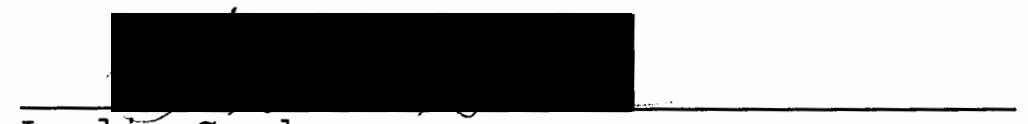
Leslie Good

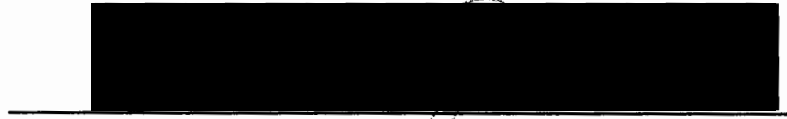

Candice Goucher

This thesis examines the contribution made by the U.S. print media to the development of Nelson Mandela's public persona. The period studied is from 1985 to June, 1990. This thesis explores the following questions: 1) How did the public persona of Nelson Mandela evolve in the dominant U.S. print media; 2) How do these stories, in content and form, serve to establish Nelson Mandela as a public hero; 3) What cultural myths structure the news stories of Nelson Mandela 
that serve as the interpretative framework for public belief and action?

Data for analysis were drawn from The New York Times, The Los Angeles Times, and The Wall street Journal. Each newspaper has a daily circulation of over 1 million.

It was found that during the period studied, the development of Mandela's public persona occurred in two distinct phases: 1985 to mid-1989 and late 1989 to June, 1990. Analysis reveals that the media relied on narrative form to create an image of Mandela which invites the reader to accept, believe in, and support Mandela and his cause. During these phases the media established Nelson Mandela as a hero and celebrity for their reader audience via a number of rhetorical practices. These include: the introduction of Mandela as a legend and hero among black South Africans; the practice of surrounding Mandela with mythical reference; establishing Mandela as an individual who subscribes to many traditional American values and; the serial reporting of pseudo-events.

Implications of the study and suggestions for further research in the areas of textual analysis, policy analysis, and audience analysis are discussed. 
THE PUBLIC PERSONA OF NELSON R. MANDELA:

A STUDY OF U.S. PRINT MEDIA NARRATIVES

\author{
by \\ MOLLY JEANNE MCVEY
}

A thesis submitted in partial fulfillment of the requirements for the degree of

MASTER OF SCIENCE

in

SPEECH COMMUNICATION

Portland State University

1993 
TO THE OFFICE OF GRADUATE STUDIES:

The members of the Committee approve the thesis of Molly Jeanne McVey presented November 4, 1993.

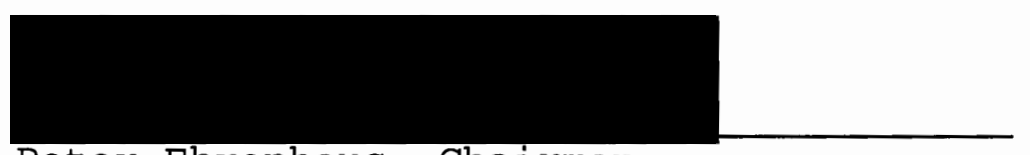

Peter Ehrenhaus, Chairman

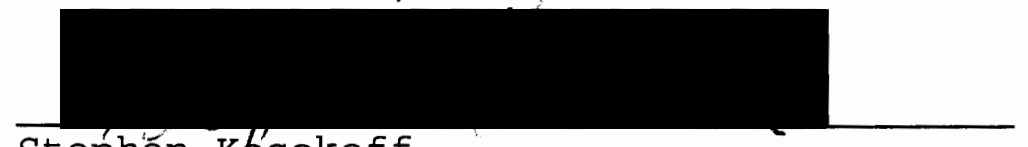

Stephēn Kb́sokoff

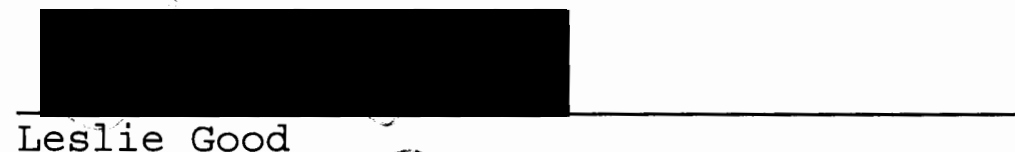

Leslie Good

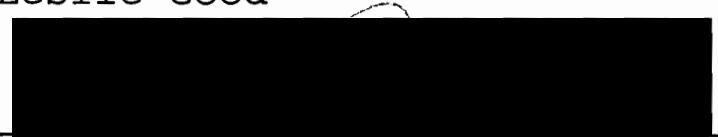

Candice Goucher

APPROVED :

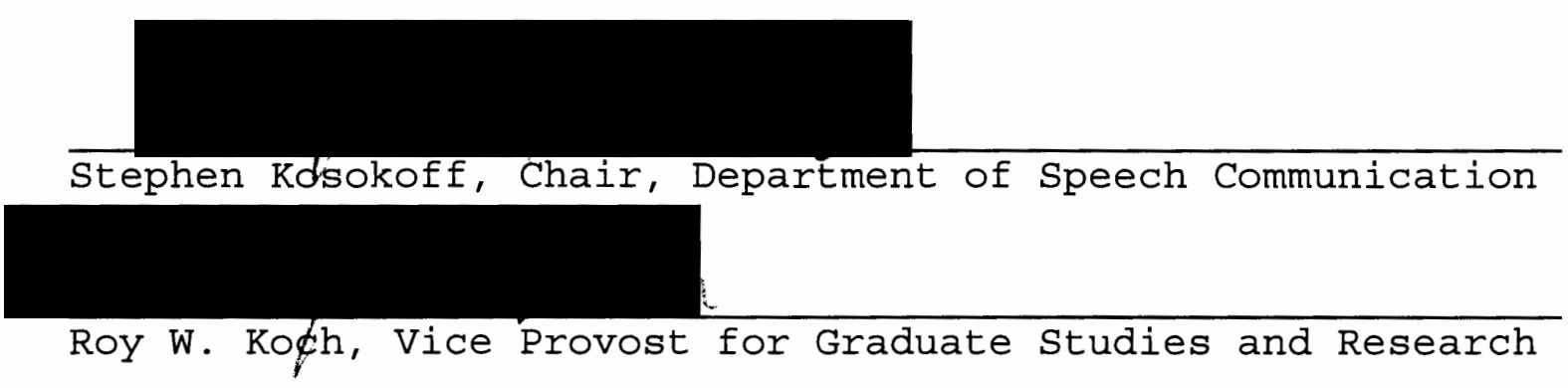




\section{ACKNOWLEDGEMENTS}

I wish to express my gratitude to Dr. Peter Ehrenhaus, chair of my committee, for his commitment to excellence in scholarship, his determination to hold me responsible for my own education, and his faith in my abilities. My appreciation to the other members of my committee: Dr. Stephen Kosokoff, Dr. Leslie Good, and Dr. Candice Goucher for their time and constructive guidance.

I am especially grateful to my husband George, my family, and my friends for their patience and continued encouragement. A special thank you to my niece Emily Brownstone for her beautiful sense of humor and her special love. 
TABLE OF CONTENTS

PAGE

ACKNOWLEDGEMENTS

CHAPTER

I

INTRODUCTION . . . . . . . . . . . . . . . . 1

Nelson R. Mandela . . . . . . . . . 1

Purpose . . . . . . . . . . . . . . . . 4

Significance . . . . . . . . . . . . 5

News and Public Consciousness . . . . 8

Research Questions . . . . . . . . 13

Key Concepts . . . . . . . . . . . . . 14

Chapter Preview . . . . . . . . . . . 17

II THEORETICAL PERSPECTIVE AND METHODOLOGY • • 18

Introduction . . . . . . . . . . . 18

Theoretical Review . . . . . . . . 18

Critical Methodology . . . . . . . 44

III HISTORICAL REVIEW OF NELSON MANDELA

AND APARTHEID POLICY . . . . . . . . . . . 52

Introduction . . . . . . . . . . . 52

Nelson Mandela and Apartheid Policy . . 53

U.S. Media Coverage of Mandela . . . 59

Summary . . . . . . . . . . . . . 73

Preview of Chapter IV . . . . . . . 76 
IV WINDS OF CHANGE--THE PUBLIC PERSONA OF

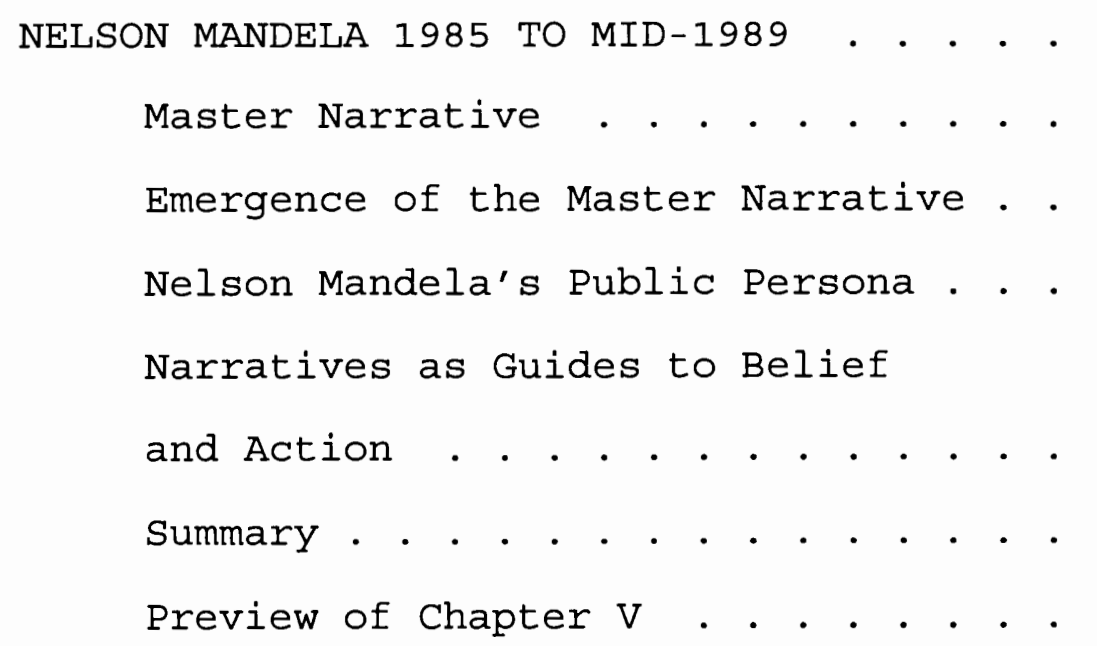

V A SYMBOL OF FREEDOM--THE PUBLIC PERSONA OF NELSON MANDELA MID-1989 TO JUNE, 1990 . . . 120 Master Narrative . . . . . . . 120

Emergence of the Master Narrative . . . 122

Nelson Mandela's Public Persona . . . 124

Narratives as Guides to Belief and Action . . . . . . . . . . . . 145

Summary . . . . . . . . . . . . . . 160

Preview of Chapter VI . . . . . . . . 164

VI CONCLUSION . . . . . . . . . . . . . . . . . 165

Introduction . . . . . . . . . . . 165

Summary . . . . . . . . . . . . . . . 166

Implications . . . . . . . . . . . 167

Suggestions for Further study . . . . . 178

REFERENCES . . . . . . . . . . . . . . . . . . 180 
CHAPTER I

\section{INTRODUCTION}

NELSON R. MANDELA

After spending twenty-seven years in South African prisons, Nelson Rolihlahla Mandela, age 71, emerged on February 11, 1990 as one of the world's most celebrated political prisoners. Mandela, a lawyer by training, has been active in South African politics for over 45 years, working for racial equality by vigorously opposing the apartheid policies of the South African government. His open opposition to apartheid resulted in a series of arrests and suspended jail sentences between 1951 and 1953. In 1956 Mandela was charged with advocating a revolution to fight apartheid. He stood trial and was acquitted in 1961. In 1962 Mandela was again arrested and sentenced to 3 years imprisonment for inciting a strike and an additional 2 years for leaving the country without government permission (Moritz, 1984). This series of arrests and convictions ended in 1963 when Mandela was brought from prison to stand trial for sabotage, high treason, and conspiracy to overthrow the government of South Africa. He was sentenced to life in prison in 1964 (Moritz, 1984). 
Today Mandela, winner of the Nobel Peace Prize, is a free man who receives the overwhelming support of the international community in the continuing struggle to end apartheid. This support raises some interesting questions regarding the basis for this support, particularly the role of the mainstream U.S. print media in shaping the public persona of Mandela for the U.S. audience.

From 1964 to June, 1990 a variety of labels have been used by the U.S. print media to describe Nelson Mandela. For example, he has been referred to as "the Black Pimpernel" ("South African Petrel," 1964), an "African Nationalist leader" ("African explains role," 1964), a "prominent black political prisoner" (Gwertzman, 1985a), the "pre-eminent black leader in South Africa" (Lelyveld, 1986b), the "most prominent symbol of the fight against apartheid" (Clines, 1988), and "...a Moses among blacks" (Kraft, 1990b).

A review of the New York Times Index inclusive of the years 1964 to 1990 revealed that media coverage of Mandela prior to the late 1980's was quite limited. During 1964 The New York Times printed approximately 20 articles covering the Mandela trial. Between 1965 and 1978 (13 years) the paper printed only nine articles, each of which mentioned his name just once, and one article which devoted a one column paragraph to Mandela (Burns, 1977a).

During the 1980's coverage of Mandela increased. Between 1980-83 four stories in The New York Times featured 
Mándela (The New York Times Index, 1980, 1982, 1983). None of these stories made the front page. In 1985 one front page article did appear on october 4 which briefly mentioned Mandela (Gwertzman, 1985a) and two articles were found elsewhere in the paper which featured Mandela (Cowell, 1985b; Dash, 1985). In 1986 Mandela gained a bit more media attention when the South African government indicated it would be willing to negotiate his release (Cowell, 1986a; Lelyveld, 1986a). Limited coverage of Mandela's possible release continued during 1987, 1988, and 1989 (Battersby, 1987; "Botha says," 1988; Battersby, 1989; Wren, 1989c; Wren, 1989d).

On February 11, 1990 articles about Mandela appeared on the front pages of U.S. newspapers when President de Klerk declared him a free man and he was released from prison. From January to June, 1990 coverage of Mandela was quite extensive, particularly for the first few weeks following his release and then again just prior to his visit to the United states.

The practice of apartheid in South Africa has been covered by the U.S. print media in varying degrees for the last 40 plus years. However, as the above summary indicates, Mandela was not a focal point in the news until the late $1980^{\prime} \mathrm{s}$ 
PURPOSE

The purpose of this study is to examine the contribution made by the mainstream U.S. print media to the development of Nelson Mandela's public persona. I will demonstrate how these news stories, which constitute media narrative in content (ideas and emotions communicated by a message) and in form (linguistic and visual elements by which the content is expressed) (Welleck \& Warren, 1970), invite the reader to accept, believe in, and support Nelson Mandela and his cause. "Mainstream" U.S. print media refers to the more influential news media which includes, among others, The New York Times, The Wall street Journal, and The Los Angeles Times (Parenti, 1993, p. 2).

News stories can be classified as "non-fiction narratives" (Sperry, 1981) or "real-life fiction" (Fisher, 1970, p. 132). An ostensive purpose of news stories is to convey real life occurrences accurately. But news reports are not merely the recounting of historical facts. These reports impose structure on events, providing us with selected details of an event, and conforming to narrative form. Hence, this study will analyze narrative qualities present in media reports about Mandela.

Mandela's public persona is developed and presented to the American public, in part, by the U.S. print media in the form of media narratives. These narratives provide a framework for the persona of Mandela and events in South 
Africa. The terms "framework" and "frame" are used to describe standard journalistic structure which includes the use of headlines, inverted pyramid style, photographs, the location of the narrative in the paper, and the tone (positive, negative or neutral) of presentation (Parenti, 1993).

This study focuses on the period from 1985 to June, 1990 (immediately prior to Mandela's visit to the United states). It is within this time frame that we see the emergence and crystallization of Mandela's American public persona.

The concern of this thesis is with media representation. Thus, it is not my intention to do an exhaustive historical review of factors contributing to the establishment of apartheid in South Africa, Mandela's imprisonment, or U.S. foreign relations with South Africa. These matters are beyond the scope of this thesis. Historically-verified information is used only to the extent that it is drawn upon in the news articles reviewed during the specified period.

\section{SIGNIFICANCE}

More than 750,000 Americans lined the streets of New York in June, 1990 to welcome the arrival of Mandela to the United States (Kifner, 1990; Lacayo, 1990). A day later 50,000 Americans cheered Mandela at Yankee Stadium (Lacayo, 
1990). Later that week he was greeted by 70,000 people during a visit to Los Angeles (Wilkinson \& Ford, 1990). The American public treated Mandela as a hero, worthy of public adulation. How might we account for this interest?

We live in an age where there is a heavy reliance on mass media to provide us with information about that which we are unable to experience first-hand. This study is grounded in arguments of various scholars (Bagdikian, 1987; Graber, 1984; Parenti, 1993) who posit that mass media, specifically news media, significantly influence our understanding of the world beyond our direct experience and hence have the opportunity to manipulate perceptions while promoting a particular viewpoint.

Be it television, newspapers, or magazines, the corporate owners of mass media are in a powerful position to influence the formation of initial perceptions and alter existing ones. This extends to the construction of our images of public heroes. The general question (one beyond the scope of any one study) is, what strategies of reporting and internal coverage do the media use that contribute to these public images? The situation of the U.S. print media's coverage of events leading up to and the release of Nelson Mandela provides an excellent context in which to seek an answer to this question. A close analysis of the creation of Mandela's public persona will contribute to a broader appreciation of the media's ability to produce heroes and 
celebrities. Moreover, a close analysis will also contribute to our understanding and intelligent evaluation of the role that mass media plays in shaping public consciousness.

The fact that the media are a primary source of information provides an opportunity for the media to promote their particular interpretation of reality, albeit while asserting their own detachment, neutrality, and fairness. For example, much, if not all, that the American public knows about Nelson Mandela and the anti-apartheid movement in South Africa is directly and/or indirectly channeled to us through the media. Parenti writes,

For many people an issue does not exist until it appears in the news media... What we even define as an issue or event, what we see and hear, and what we do not see and hear are greatly determined by those who control the communication world. Be it peace protestors, uprisings in Latin

America... few of us know of things except as they are depicted in the news. (1993, p.1)

How is it that the public comes to accept certain stories as truth? And how do they influence our actions? It is important to consider these questions if we accept the premise that media stories influence the formation of our concepts of reality. For as Graber states,

Rarely have we enough information and understanding to form our own views about the many complex national and international issues that succeed one another with bewildering rapidity. This puts us at the mercy of the media, not only for information, but also for interpretation. Even when we think that we are forming our own opinions about familiar issues, we may be depending on the media more than we realize. (1984, p. 142) 
The following is a brief review of significant issues about news stories and their potential influence on public perceptions. Issues touched on here will be developed more thoroughly in the following chapter.

\section{NEWS AND PUBLIC CONSCIOUSNESS}

Sperry claims that in non-fiction narrative [e.g., news stories] there is a relationship that exists between the teller and listener which is based on a mutual (if not explicit) understanding that the non-fiction narrative is a compromise between "Truth" and the listener's expectations of a "coherent and effective (or affective) form" (1981, p. 298). Key to understanding this relationship is the credibility of the narrator.

When examining the creation of the public persona of Mandela we must remember that the persona is a creation of the accounting of various selected facts and events, told and retold over a period of time by selected narrators within the framework of journalistic structure. The critic (and all readers) must consider the credibility of the narrator when determining the believability of a story.

It is unlikely that the average American would be personally familiar with the honesty, integrity and character of a particular journalist. Rather, the public relies on the reputation of the newspaper corporation; the journalist, as an agent of the corporation, is assumed to 
possess the same credibility as the employer. Consequently, from the reader's perspective, it is really the newspaper corporation that is the narrator of news stories. For example, one usually refers to the author of an article as "the paper says" not "reporter Anderson says." The role of the narrator of news stories is consistent with Iucaites and Condit's description of the rhetorical narrator.

Because the speaker [in this case the journalist and newspaper corporation] in a rhetorical situation always seeks material gain in some measure, he or she is literally invested in the outcome of the rhetorical process and is therefore expected by an audience to assert and accept responsibility for the power and veracity of the narratives that are featured in a discourse. (1985, p. 101)

Generally speaking, newspapers such as The New York Times, The Wall street Journal, and The Los Angeles Times are viewed by the public as being credible sources of information. Aside from somewhat conservative leanings, these papers are perceived as adhering to the journalistic guidelines of objectivity which include value exclusion. However, Gans claims that objectivity itself is a value and that values are "built into news judgments" through "story selection and opinions expressed in specific stories" (1979a, p. 182).

Journalists and editors, by the nature of their positions, have the authority to decide which elements of a story will be highlighted and which will be suppressed or ignored. The decisions made are influenced by a number of 
factors including national and international politics, economics, private business interests, and individual perceptions and interpretations of events (Bagdikian, 1987; Cohen, 1963; Gans, 1979a; Tuchman, 1978). While it is not the purpose of this study to delve into the special interests which motivate mass media corporations and influence the selection of information for reporting, a brief review of mass media ownership illustrates factors which contribute, specifically, to the type and degree of coverage Nelson Mandela has received in the American print media.

According to Bagdikian, technological achievements and American economics have been instrumental in the creation of a "central authority over information--the national and multinational corporation" (1987, p. xix). These corporations exert a strong influence, based on their political and economic interests, over the type and amount of information the American public receives. As of 1987, the majority of all major American media--newspapers, magazines, radio, television, books, and movies--are controlled by fifty giant corporations, with fifteen of those corporations dominating the daily newspaper industry (Bagdikian, 1987). Bagdikian writes that through their boards of directors newspaper corporations, as well as other mass media, have formed "interlocks" with "major industrial and financial sectors of the American economy" which influence the 
distribution of information (1987, p. 25). For example, Gannett Company, which owns USA Today and 93 other daily newspapers with a total daily circulation of over 6 million, shares directors with the boards of Kellogg Company, McGrawHill Inc., and Standard Oil of Ohio, which have businesses operating in South Africa (Bagdikian, 1987; Lashgari and Gant, 1989). Likewise, The New York Times, with a daily circulation of over 1 million shares directors with BristolMyers Co., Merck \& Co., and American Express which also have business interests in South Africa. Altschull sums up the situation nicely when he writes that, "...an independent press, free from the influences of those who hold economic, political, and social power cannot exist" (1984, p. xi). Gans (1979a), in his study of television network evening news and weekly news magazines, found that foreign news tended to follow American foreign policy in their coverage of foreign events with an emphasis on stories deemed most relevant to American interests and values. American foreign policy influences the success or failure of overseas investments by American corporations (Bagdikian, 1987). Corporations with business interests in South Africa, many of which have close associations with U.S. newspaper corporations, have a vested interest in seeing that our foreign policies toward South Africa protect their corporate interests. 
Gitlin provides support for the idea that the media provides the political and economic elite with a channel for the promotion and support of government policies which protect their interests in South Africa. He writes: "The closer an issue is to the core interests of national political elites, the more likely is a blackout of news that effectively challenges that interest" (1980, p. 5). The opposite can also occur; issues which reinforce and serve to further the interests of the political elites are more likely to receive substantial coverage. As Bagdikian points out, "There is a general consensus among political scientists that even though the media are unable to tell us how to think it can tell us what to think about" (1987, p. $x x)$.

An extensive review of large U.S. newspapers (e.g., The New York Times, The Los Angeles Times, The Wall street Journal, and USA Today) and smaller newspapers (e.g., San Francisco Chronicle, Oregonian, and Statesman Journal) showed that virtually all articles featuring Nelson Mandela were written by special correspondents for the larger newspapers and Associated Press reporters. The majority of daily newspapers in this country, along with radio and television news programs, depend almost entirely on the Associated Press for information regarding foreign news (Cohen, 1963; Graber, 1984; Parenti, 1993). Associated Press stories selected for publication by various papers are 
sometimes condensed to adjust to limits on space, but generally, the stories remain essentially the same. The result is homogeneous news. We have a few journalists writing for a massive audience. Parenti reminds us that the media can direct our perceptions when we (the public) have little knowledge or information that is contrary to a media message and when the message appears to be "congruent" with earlier notions about events, persons, and objects, etc. (1993, p. 23). When we assume that news stories are objective, unbiased representations of reality we are neglecting to consider the influence of the aforementioned factors on the construction of that reality, which encompasses the images of our public heroes.

\section{RESEARCH QUESTIONS}

This thesis seeks to answer the following questions:

1. How did the public persona of Nelson Mandela evolve in the dominant U.S. print media?

1A. How do these stories, in content and form, serve to establish Nelson Mandela as a public hero?

2. What cultural myths structure the news stories of Nelson Mandela that serve as the interpretative framework for public belief and action? 
KEY CONCEPTS

The following provides definitions for key concepts used throughout this thesis. The definitions follow the order in which the concepts are introduced in this study.

Mainstream U.S. print media refers to The New York Times and The Los Angeles Times which have a daily circulation of over 1 million each, and The Wall street Journal which has a daily circulation of over 2 million (Boyden, 1989).

Persona is the personality assumed by an individual in adaptation to the outside world (The New Lexicon Webster's Dictionary, 1987). For this study the use of the words "public persona" and "persona" refers to the media's presentation of Mandela's personality.

Hero is defined as: "a human figure--real or imaginary or both--who has shown greatness in some achievement. He is a man or woman of great deeds" (Boorstin, 1961, p. 49).

Legend refers the characterization of Mandela found in a story or body of stories that have been handed down among various people during Mandela's imprisonment. The word "legend" has been used repeatedly in news media reports as an adjective to describe a collective perception of Mandela. 
Narrative is defined as: a complete story (a beginning, middle, and end) which provides the reader with a "completely developed point and a satisfying conclusion" (Sillars, 1991, p. 156). The narrative "is based on experience, is a product of the memory, has a sense of chronology about it, is coherent, and defines a central subject" (Sillars, 1991, p. 156).

Master narrative refers to the compilation of several news reports during a specified period. The term "master narrative" is based on Bird and Dardenne's opinion that news stories can best be understood by examining them as "both a body of work that is a continuing story of human activity, and as individual stories that contribute to that continuing one" (1988, p. 69).

Cultural myth is defined as, "a body of narrative woven into a culture to dictate belief, define ritual, and act as a chart to the social order (Breen \& Corcoran, 1986, p. 201). "A myth is a story that the members of a particular culture use to explain themselves" (Sillars, 1991, p. 123). Every culture has certain basic values. Those values are often passed on and taught to members of the culture through the use of myths. Strictly speaking myths are often defined as untrue stories about characters who never existed. American stories of Paul Bunyan fit this description. In this study 
the term "myth" also refers to factual stories which can be used to illustrate desirable states of being and/or modes of action for individuals. The characters, scene, and action in a mythic story can vary, but the central theme remains the same. This is how an individual can identify reference to a particular cultural myth in seemingly unlike stories. For example, Larson claims in our society a myth exists which posits that "wisdom is gained only through great challenge and testing" (1989, p. 227). He has labeled this myth "Value of a Challenge." The comic strip "Prince Valiant" is an example of a story that is repeated over and over and perpetuates the "Value of a Challenge" myth. The prince is continually challenged and tested and as he meets those challenges and passes those tests he becomes a wise man whose advise is sought after. In the same vein, stories have been told and books have been written about Lee Iaococa, one of our nations most prominent businessmen. Iaococa is portrayed as a man who faced seemingly insurmountable problems relating to Chrysler Corporation. He was severely challenged and tested, but he prevailed and in doing so he has become a celebrity who is sought after for his business acumen. These two examples have very different characters, scene, and action but the essence of the myth is the same; wisdom is gained through great challenge and testing. 
CHAPTER PREVIEW

The following format will be used for the remainder of this thesis. Chapter II outlines the theoretical and conceptual foundations for analyzing the news narratives, and introduces the critical methodology. Chapter III provides historical background on Nelson Mandela and apartheid policy in South Africa, and includes a review of news stories prior to 1985. Chapters IV and V follow a chronological order and cover the periods from 1985 to mid1989, and late 1989 to June, 1990 respectively. A preliminary review of the news reports suggests that there are two fairly distinct phases in the development of Mandela's public persona. During the first phase, from 1985 to mid-1989, Mandela's role in the news reports begins to change from that of non-participant to a co-agent/actor in a master narrative which is dominated by the political and social scene in South Africa. During the second phase, from late 1989 to June, 1990, Mandela is transformed from coagent/actor to the central character and ultimately becomes the scene, he comes to embody the central purpose of the master narrative, he becomes the symbolic representation of millions of black South Africans struggle for freedom. These chapters include my description, interpretation, and evaluation of various narratives. Chapter VI summarizes the results and implications of this study. Suggestions for further research are presented. 
CHAPTER II

THEORETICAL PERSPECTIVE AND METHODOLOGY

\section{INTRODUCTION}

This chapter provides a review of the theoretical foundations for this thesis and a discussion of the study's methodology. The following is a review of relevant literature in dramaturgical theory and its relationship to mass media. I begin with a review of literature relating to news-as-narrative. I then move to Kenneth Burke's views on dramatism, and to Bormann's views on symbolic convergence theory--both of which have influenced narrative analysis. I conclude this review of literature with a review of various perspectives on narrative and myths. A discussion of my critical methodology, which is based in these literatures, concludes this chapter.

\section{THEORETICAL REVIEW}

This thesis is grounded in the general perspective of dramaturgical theory. More specifically, it draws upon work in the related domains of dramatism, symbolic convergence theory, and narrative theory. Each of these perspectives views the creation of stories as a fundamental function of human communication. Humans are by nature story telling 
animals. The construction of narratives (stories) directs our perceptions, and impacts our judgments and knowledge. Narratives shape our reality by giving meaning to the relationships between situations, subjects, and events (Lewis, 1987). Rushing writes, "Not only do we understand our own actions in terms of narrative structure, but we find purpose and guidance for our lives in accord with the stories told by the society in which we live" (1986, p. 265). In other words, narratives give order to events, actions, ideas, and behaviors.

\section{News as Narrative}

Scholars argue that consumers of news tend to take it for granted that newspapers present information for consumption in an accurate, objective, unbiased fashion (Bagdikian, 1987; Gans, 1979a; Gitlin, 1980; Parenti, 1993; Tuchman, 1978). In other words, most believe that what we read and listen to as reported by the U.S. media is an accurate representation of reality. Gitlin, in keeping with the notion that much of what we believe about our world comes to us indirectly, claims that,
From within their private crevices, people find themselves relying on the media for concepts, for images of their heroes, for guiding information, for emotional charges, for a recognition of public values, for symbols in general, even for language; ...they [media] certify reality as reality. (1980, pp. 1-2)

The news media not only reinforce these images, but they are instrumental in the creation of them as well. Specifically, 
these news narratives contribute to the shaping of the public's perception of Mandela and South Africa and can influence public behavior. As Gitlin argues, "...the media specialize in orchestrating everyday consciousness--by virtue of their pervasiveness, their accessibility, their centralized symbolic capacity" (1980, p. 2).

The amount and type of media response to an event defines its significance. Both Parenti (1993) and Severin (1988) refer to this phenomenon as "agenda setting." The news media are able to influence what the public thinks and talks about by selecting what to report, how it is reported, and the extent of coverage. Newspaper owners, publishers, and editors are in a position to act as gatekeepers of information in that they are the ones who decide what is reported and to what extent. Research shows that "those topics given the most coverage by the news media are likely to be the topics audiences identify as the most pressing issues of the day" (Tuchman, 1978, p. 2). Specific to this thesis, The New York Times and The Los Angeles Times, and The Wall street Journal, in conjunction with other print and broadcast media, adhere to an agenda which specifies what is to be believed or disbelieved, accepted or rejected regarding Mandela and events in South Africa.

Bagdikian believes that the media have the power to influence public opinion by covering events, persons, or ideas in depth, over a period of time until a "coherent 
picture" is formed that becomes "integrated into public thinking" (1987, p. 17). Bennett refers to this type of reporting as "serial" or "long-playing" news which captures the attention and shapes the emotions of the public (1983, p. 5). Both Bagdikian and Bennett argue that this type of reporting raises the question of whether the news is an accurate reflection of society or whether public opinion (perceptions) are created by the news. Bagdikian writes,

Americans, like most people, get images of the world from their newspapers, magazines, radio, television, books, and movies. The mass media become the authority at any given moment for what is true and what is false, what is reality and what is fantasy, what is important and what is trivial. There is no greater force in shaping the public mind; even brute force triumphs only by creating an accepting attitude toward brutes. (1987, p. xviii)

If one were to argue that U.S. media merely recounts historical facts, the resulting effect on public beliefs, attitudes, and actions would be limited. News reports might take the form of a chronological list of events such as:

February 11, 1990: Nelson Mandela released from prison.

February 12, 1990: Mandela speaks before a crowd of 12,000 .

But they do not. Their reports are narratives which include themes, values, characters, and a narrative voice within a journalistic structure. White (1981) views narrative as a possible solution to the translating of "knowing into telling," and suggests that narrative is necessary if 
reconstructed events are to have meaning (p. 1, italics in original). Unlike annals and chronicles, which are limited to listing events in a chronological order, narrative "endows experience with meaning" and provides insight into the "nature of real events" (White, 1981, pp. 5-6). White also suggests that narrative is a "metacode" that allows for the messages of reality to be transmitted within and across cultures (1981, p. 2). Therefore, if news reporting is to have meaning for the reader, the report must be more than a chronological accounting of events; it must take a story form. This narrative or story form with its narrator, characters, plotline, and resolution provide "substance" or meaning for the reader.

Scholars generally agree that in order for communication to take the form of narrative there must be a teller, tale, and listener. Epstein expands the required elements of narrative (specifically news reports) when he writes,

Every news story should, without any sacrifice of probity or responsibility, display the attributes of fiction, of drama. It should have structure and conflict, problem and denouement, rising action and falling action, a beginning, a middle and an end. These are not only the essentials of drama: they are the essentials of narrative. (1973, pp. 4-5)

Tuchman (1978) argues that the act of making news (creating stories) is the act of constructing reality rather than a picture of reality itself. Tuchman claims that media news stories are a selected reality with their own internal 
validity that can be distinguished by recurring themes and forms. The public has come to expect news narratives to be structured in a particular fashion. They are expected to have a particular form. For example, Tuchman identifies the writing of headlines in present tense, stories written in past tense, word ordering, and short paragraphs and sentences as illustrative of the narrative form of news stories (1978). Similarly, Schudson has identified the following as primary "news conventions" (narrative forms) used by the media which shape and limit the kinds of information reported.

1) A summary lead and inverted pyramid structure are superior to a chronological account of an event.

2) A news-story should focus on a single event rather than a continuous or repeated happening, or that, if the action is repeated, attention should center on novelty, not on pattern.

3) That a news story covering an important speech or document should quote or state its highlights.

4) That a news story covering a political event should convey the meaning of the political acts in a time frame larger than that of the acts themselves (1982, p. 99).

Parenti (1993), Bagdikian (1987), and Gitlin (1980) claim that the media rely on "media frames" to organize events, beyond a reader's direct experience, into a narrative that makes sense to or appears "natural" to the reader. Gitlin writes,

What makes the world beyond direct experience look natural is a media frame.... Even within a given event there is an infinity of noticeable details. 
Frames are principles of selection, emphasis, and presentation composed of little tacit theories about what exists, what happens, and what matters....Media frames, largely unspoken and unacknowledged, organize the world both for journalists who report it and, in some important degree, for us who rely on their reports. Media frames are persistent patterns of cognition, interpretation, and presentation, of selection, emphasis, and exclusion, by which symbol-handlers routinely organize discourse, whether verbal or visual. (1980, pp. 6-7)

Parenti (1993) suggests that framing can be used to subtly promote a particular ideology. And Gitlin argues that the media are, "a significant force in the forming and delimiting of public assumptions, attitudes, and moods--of ideology, in short" (1980, p. 9).

Narrative plays a key role in the formation of political and social consciousness in a mass mediated society. Lucaites and Condit used the terms poetic, dialectical, and rhetoric to identify or categorize various types of narrative as they explored the role of narrative in the formation of political and social consciousness" (1985, p. 90). Traditionally, poetic discourse has been defined as "the art of storytelling in the form of drama and the epic" (Aristotle, 1954, p. 4). Dialectical discourse has been defined as "the art of reasoned discourse" (Golden, Bergquist, \& Coleman, 1989, p. 30). Rhetoric was defined by Aristotle as "the faculty of observing in any given case the available means of persuasion" (1954, p. 24). Lucaites and Condit based their study on the assumption that "all discourse is designed to achieve at least one of three 
goals-to delight [poetic], to instruct [dialectic], and to move [rhetoric]" (1985, p. 92). They go on to say that the function of dialectical narrative is to

...illuminate the factual nature of the universe as a means of providing information for human use. The essential characteristic of a dialectical narrative, therefore, is its content, which is constrained by criteria of accuracy and external validity. (1985, p. 93)

News reports fall into this category of narrative.

However, Lucaites and Condit (1985) stress that the forms and functions of narrative genre do overlap in single narratives. Hence, it would not be advisable to say categorically that news stories are strictly dialectical. They can and do contain qualities of the poetic and rhetorical. In other words, a news story's primary function is to convey factual information, but it can also entertain and persuade an audience. In fact, the rhetorical (persuasive) function of narrative may supercede the dialectical function. Recall that news reporting is a business and the success of the business depends to a great extent on the selling of newspapers. Part of a newspaper's success depends on their willingness to present narratives (stories) to the public that are consistent with previous stories and audience expectations.

Lucaites and Condit also claim that studies of narrative must take into consideration their usefulness in "enhancing critical awareness of human interaction." This can be discovered by giving careful attention to the "social 
and political implications" of the narrative form (p. 105). They conclude:

If narrative does constitute a paradigm of human communication, then it must operate in every imaginable genre of discourse, not just the purified forms of rhetoric, poetic, and dialectic, but in all of the alloys of these forms that seem to dominate contemporary mass society. (1985, p. 104)

In their discussion of news stories as narrative, Bird and Dardenne define news stories as, "culturally constructed narratives" which are both a "reflection and representation" of culture (1988, p. 68). They suggest that understanding can be achieved if one

...look[s] at news stories as a whole--both as a body of work that is a continuing story of human activity, and as individual stories that contribute to that continuing one. (1988, p. 69)

This approach allows us to go beyond the facts, figures, and names in stories to discover the "symbolic system of news" which Bird and Dardenne feel is more "enduring" to the reader (p. 69). In other words, readers learn more from a news story than just historical data; they learn a system for the ordering of human events. Bird and Dardenne conclude from their discussion that media, "are very much a part of our culture, but with a particular kind of privileged status within it," because journalists use patterns of story telling that reflect the current ideology, and these patterns are perceived by the majority as being "natural" or "common sense" (p. 82). 
Boorstin (1961) claims that we (the public) expect and demand that newspapers be full of interesting if not exciting news, and hold the papers responsible for making our world interesting. In an effort to accommodate these demands, Boorstin argues that there has been a change from the reporting of spontaneously occurring events (e.g., natural disasters, a former meeting between the president and foreign dignitaries) to the fabrication of "pseudoevents" (e.g., possible earthquake, expected summit meeting) in order to satisfy the public's demand for the illusion that there is an exciting world out there (1961, pp. 4-5). He defines a pseudo-event as, "an ambiguous truth...containing synthetic facts which move people indirectly, by providing the 'factual' basis on which they are suppose to make up their minds" (p. 34). A pseudo-event is, "not spontaneous... is planted primarily for the immediate purpose of being reported or reproduced...its [the event's] relation to underlying reality of the situation is ambiguous... and the event is usually intended to be a selffulfilling prophecy" (pp. 11-12). Larson describes a pseudoevent as a "hybrid somewhere between public relations and hard news" (1989, p. 352). Pseudo-events are "planned news," planted in the news to draw attention to individuals and/or events. They tend to take a highly dramatic form (Larson, 1989). 
In addition, Boorstin tells us that our ability to create pseudo-events and our preference for such events in the news encompasses the realm of humans as heroes and celebrities. The media has the power to create "wellknownness" and in so doing has obscured the distinction between heroes (great people) and celebrities (famous people) .

Boorstin defines the celebrity as "the human pseudoevent" (1961, p. 57). The celebrity is a product of the media's ability to create "well-knownness" (p. 57). Heroes are people who are admired for their courage, nobility, or exploits. Whereas heroes usually become famous slowly, over time, celebrities, with the help of the media, can become famous almost instantly (Boorstin, 1961).

Boorstin claims that the public often confuses celebrity status and hero status. We label individuals as heros when in actuality they are celebrities made famous by the media. For example, Lech Walesa, Poland's hero of the common person, possesses qualities of greatness (selfsacrifice, nobility, etc.) but he is perhaps less well known to the average American than is Michael Jordan, who is a talented athlete and certainly famous, but is no hero. And yet Jordan is often referred to in heroic terms.

A situation can also exist in which an individual can be identified as both a hero and celebrity simultaneously. In this situation a person is recognized for their heroic 
qualities and deeds as well as their "well-knownness." As I shall demonstrate, this is the situation with Nelson Mandela in the U.S. media. He is a media created celebrity (a humanpseudo event) who also has hero status. He is a media hero created by the dominant print media for its conventional audience. One measure of the dominance of the hero persona is the outpouring of welcome he received during his visit to the U.S. The welcome reflects an acceptance of the media narrative by the general public.

Various scholars are of the opinion that there is a bias in news (both electronic and print) toward heroic narrative and melodramatic conventions (Lawrence and Timberg, 1979; Sperry, 1981; weaver, 1976). As Sperry puts it, "Each individual news story is a small but distinct narrative, with a recognizable plot of action which sets character against character in a struggle to redeem the world" (1981, p. 303). This hero narrative is not only seen in individual stories printed only once, but in long-playing stories that may stay in the news day after day (Lawrence \& Timberg, 1979). Although we may not be consciously aware of it, the ability to recognize these stories as hero narratives lies in their similarity to hero-based cultural myths.

News narratives are constructed views of reality (Gitlin, 1980; Tuchman, 1978). They contain underlying values which we rely on as guides for beliefs and action. 
These values are often reflected in our public heroes and celebrities as presented to us by the media.

An examination of the evolution of the public persona of Mandela provides an opportunity for identifying the presence of or reference to value-laden myths in media narratives. As I shall argue, one reason the American public has come to accept Mandela as a hero is because many of the narratives which focus on Mandela contain reference to value based myths which cast Mandela in the role of the hero. Lawrence and Timberg claim that if we want to understand the nature of heroic news we must look to the "mythic traditions of a culture" (1979, p. 323). It is within these mythic traditions that we will find our definitions of our heroes.

Gans tells us that foreign news (e.g. coverage of Mandela and South Africa) is generally "treated with less detachment, and explicit value judgments that would not be considered justifiable in domestic news appear in stories about the rest of the world" (1979a, p. 31). These values can be either implicit or explicit and function as warrants (good reasons) for accepting a particular news narrative. For example, in the editorial "Yes to Mandela's Way," Mandela and the ANC are shown to value peaceful cooperation, which is consistent with American values. The article stated,

The African National Congress, the organization at the center of the black struggle, has publicly reaffirmed its determination to negotiate. And Nelson Mandela, its leader and soul, has offered a 
courageously moderate basis for negotiations. (1990, p. 26)

Both Fisher (1984) and White (1981) assert that any narrative, particularly one that gives an account of reality (e.g., news story) contains a moral dimension derived from value systems. In other words, value systems (values that are associated with one another) supply the basis for determining what is good or right in conduct or character (Sillars, 1991). These value systems are the essence of cultural myths. Bennett (1980) writes that, "Myths are used as models for applying the values and beliefs from which public opinion emerges" (p. 168). And Doty explains that, "...myths and rituals both reflect and project valuational frameworks; they provide scenarios for action a well as reflecting or distorting mirrors" (1986, p. 29).

According to Lustig (1988), narratives in all their various forms, which includes the U.S. media, continually reinforce, directly or indirectly, American values that generally go unnoticed or unquestioned by the majority. Values, or "mental programing" as referred to by Lustig (p. 56), are so much a part of a person's mental framework that one often has difficulty identifying values and their relationships to behaviors. And yet, "a culture's values provide the basic set of standards and assumptions that guide thought and action" (Lustig, 1988, p. 56). Research by Graber (1984) shows that foreign news reports consistently reflect the American value structure and American 
stereotypes of other cultures. Gans found that the inclusion of foreign news in the U.S. media is based on how relevant particular stories are to American interests and values (1979a). For example, the image (a stereotype) of South Africa as an active volcano of human violence prone to frequent eruptions continues to be privileged in the U.S. media. In June, 1990 Thurow described white conservative reaction to de Klerk's lifting of the ban on the ANC and Mandela's release. He wrote,

From the Vortrekker Monument in Pretoria, the sacred shrine of Afrikanerdom, comes the pounding of 100,000 feet stomping defiantly as a mass rally called by the pro-apartheid Conservative Party. A banner held aloft at the gathering proclaims, "White nation-hood is greater than death." From all across the platteland comes the rebellious message: Stop the reforms, or else. (1990a, p. Al)

An article which suggested that the events in South Africa were or should be important to Americans was written by Thurow. He wrote,

In Washington, President Bush and many members of congress praised Pretoria for freeing $\mathrm{Mr}$. Mandela, but made clear the action wouldn't by itself prompt the U.S. to immediately sweep away economic sanctions imposed on South Africa in 1986.... However, Mr. Bush is showing strong support for $\mathrm{Mr}$. de Klerk, including inviting him to visit Washington. The president invited Mr. Mandela as well, in a congratulatory telephone call yesterday. (1990e, pp. Al, 7)

Recall that previous to levying economic sanctions on south Africa, the U.S. had been one of South Africa's largest trading partners. Both countries would benefit financially from the lifting of those sanctions. 
Both Bennett's (1983) and Gans' (1979a) work address the inclusion of mainstream American values in news stories. Bennett claims that through a process of "normalization the news takes us on a daily tour of the world-as-it-ought-tobe: a world filled with mainstream American values, and comforting images of authority and security" (p. 25). The normalization (limiting of diverse viewpoints and experience) of news has the effect of narrowing the reader's perception of the world around them. Bird and Dardenne claim that by examining the "narrative qualities of news" we can identify the values present in the stories (1988, p. 79). And Gans (1979b) argues that news stories contain "values, or preference statements" which makes it possible to "suggest that there is, underlying the news, a picture of nation and society as it ought to be" (p. 40). The values that Gans writes of are seldom obvious, but can be discovered by focusing on what is reported and what is ignored, and by examining language and how it is used in a story to describe events and persons (1979a; 1979b). If we are to understand the ability of media coverage to shape the public consciousness regarding Mandela, we must identify the cultural myths (hence, the values) present in that coverage.

\section{Dramatism}

Kenneth Burke's theory of dramatism focuses on humans as symbol-creating and symbol-using creatures who use both verbal and nonverbal language to fill a fundamental need for 
social interaction. Burke contends that humans account for or explain their world through the use of dramatic terms. our messages take the form of dramas. Burke states that whenever we describe a situation we answer five questions: "What was done (act), when or where it was done (scene), who did it (agent), how he did it (agency), and why (purpose) (1962, p. xviii). Furthermore, Burke posits that when we create a dramatic message we will emphasize or highlight a particular term or element (e.g., scene, act, purpose). The way in which the elements of the message are ordered and the emphasis placed on an element indicate the rhetor's adherence to a particular philosophical school. Proponents of various philosophical schools will feature or emphasize different elements in their dramatic message (Burke, 1962). Ling explains,

.. The materialist school adopts a vocabulary that focuses on the scene as the central element in any situation. The agent, act, agency and purpose are viewed as functions of the scene. On the other hand, the idealist school views the agent (individual) as central and subordinates the other elements to the agent.... Thus, both the materialist and the idealist, looking at the same situation, would describe the same five elements existing in that situation.... [but] each views a different element as central and controlling. (1970, p. 344)

Burke uses the "pentad" as a tool for examining messages in terms of both content and form. The pentad, consisting of five elements: act, agent, agency, scene, and purpose, is used to discover the "motives" of a message. Motive is the reason for the performance of the act and 
rises out of a particular philosophical school. Foss, Foss, and Trapp write that a motive "...might be thought of as a 'rough shorthand description' of a situation or the terminology we use to interpret a situation" (1985, p. 170). Identification of motive answers the question of how readers are to understand and interpret the rhetor's view of the situation. Foss (1989), in a discussion of Burke's writing, concludes that "Once a critic knows how a rhetor has described a situation, the critic is able to discover that rhetor's motive for action in the situation" (p. 336). Foss et al. (1985) indicate that Burke's pentad corresponds with journalists' questions of "Who? (agent), What? (act), Why? (purpose), When? and Where? (scene), and How? (agency)" (p. 336).

Burke notes that as one element of the pentad changes we can expect pressure to be exerted on the other elements (to varying degree) to also change. He writes:

It is a principle of drama that the nature of acts and agents should be consistent with the nature of the scene. And whereas comic and grotesque works may deliberately set these elements at odds with one another, audiences make allowances for such liberty, which reaffirms the same principle of consistency in its very violation. (1969, p. 3)

In a given text we will find that some element (e.g., agent) will be highlighted or in the foreground and other elements will reside in the background (e.g., agency, purpose, act). There is a tension that exists between each element to varying degrees and if the dominant or featured element 
changes as the text progresses we can expect to see a change in the degree of tension between selected elements.

According to Burke, it is the tension or the ratio of tension which exists between elements that helps us to understand motive. I expect that a study of media narratives will reveal featured terms, and tension that exists between various terms which in turn contributes to the reader's perception of Mandela and South Africa. For as Ling writes:

If persuasion is viewed as the attempt of one man [the media corporation] to get another [the American public] to accept his view of reality as the correct one, then the pentad can be used as a means of examining how the persuader has attempted to achieve the restructuring of the audience's view of reality. (1970, p. 346).

In addition to the pentad, Burke introduced the concepts of consubstantiality and identification to dramatistic criticism. Consubstantiality refers to the common ideas, attitudes, possessions or properties that one individual shares with another individual (Foss et al., 1985). For example, two individuals may be consubstantial when they share the same attitude, or when their interests overlap.

Closely associated with consubstantiality is identification. In fact, the two terms are often used synonymously. Foss et al. write that, "shared substance constitutes an identification between an individual and some property or person...." (1985, p. 158). Consubstantiality and identification influence persuasion. As we use symbols 
(language) to identify our consubstantiality those symbols become significant in that they allow us to achieve shared meaning. The significant symbols represent one's consubstantiality and through the communication of these symbols our identification with others can increase or decrease. As we increase identification, persuasion increases. According to Foss et al. (1985) the form of a rhetorical act can promote identification. The rhetor (media) can use an accepted form (traditional journalistic structure) to frame a story and that form can function as a persuasive tool in the public's acceptance of the content of the story.

Symbolic Convergence

In the same general vein as Dramatism, we find Symbolic Convergence theory, which explains how groups of people, after engaging in numerous communication episodes over an extended period of time may come to share a similar social reality (Golden et al., 1989). This general theory of communication, "assumes that human beings are story tellers who share fantasies and thus build group consciousness and create social realities" (Bormann, 1985, p. 136). The fantasies of a group are often (but not exclusively) expressed in the narrative form which includes characters (both good and bad); a plotline (the action or development of the story); a scene (the setting where the action takes place); and a sanctioning agent (a source that legitimized 
the story--an authority or ideal) (Bormann, 1972, 1985;

Littlejohn, 1989). The substance of these rhetorical

fantasies can include either real or fictitious characters and events. The fantasies can consist of actual experiences of the group, or things that have been reported in "authenticated works of history, the news media, or in the oral history and folklore of other groups and communities" (Bormann, 1985, p. 130). Bormann writes:

When members of a mass media audience share a fantasy they jointly experience the same emotions, develop common heroes and villains, celebrate certain actions as laudable, and interpret some aspect of their common experience in the same way. They thus come to what I call a "symbolic convergence" about that part of their common experiences. (1985, p. 131)

As group members share fantasies (dramatic messages) fantasy themes begin to develop. These themes are the "content of the dramatizing message that sparks the chain of reactions and feelings" (Bormann, 1985, p. 131) of group members. Fantasy chains develop when fantasy themes are spread through a community. Bormann argues that fantasy themes, which are adopted by and chain-out in small groups, can be and often are

...worked into public speeches and into the mass media and, in turn, spread out across larger publics, [they] serve to sustain the member's sense of community, to impel them strongly to action... and to provide them with a social reality filled with heroes, villains, emotions, and attitudes. (1972, p. 398)

One such type of fantasy that can be shared via the narrative form is the cultural myth (See p. 41). 
Perspectives on Narrative

Fisher's concept of "narrative paradigm" draws on and is supported by Burke's view of humans as symbol-creating and symbol-using animals and Bormann's views on symbolic convergence. In essence both perspectives serve as a foundation for Fisher's claim that "all forms of human communication need to be seen fundamentally as stories-symbolic interpretations of aspects of the world occurring in time and shaped by history, culture, and character" (1989, p. 57).

Fisher defines narration as "A theory of symbolic actions--words and/or deeds--that have sequence and meaning for those who live, create, or interpret them" (1984, p. 2). If we view rhetorical communication as stories rather than arguments, Fisher tells us that we can make three important discriminations:

1) one will focus on the sequences of symbolic actions and their meaning, 2) one will recognize that no text is devoid of historical, situational, and biographical context, and 3) one will recognize that the meaning and value of any account are always influenced by how the account or story stands with or against other stories known to an audience or other observer. (1987, p. 144)

He has labeled rhetorical communication that "relates to reality in both subject matter and purpose" as "realfiction." (1970, p. 132). News stories fall into this category since their primary purpose is to convey accurately, real life occurrences. When we use the narrative 
paradigm to examine discourse, the texts are viewed as "...verbal phenomena composed of good reasons...as elements that function as warrants for believing or acting in accord with the message of the text" (1987, p. 143). The focus is on the message, the forms that constitute the message, and on the reliability, trustworthiness, and desirability of what is said. Good reasons provide "warrants" for accepting or rejecting a particular story. Fisher defines "warrant" as, "...that which authorizes, sanctions, or justifies belief, attitude, or action--these being the usual forms of rhetorical advice" (1987, p. 107). Reasons are good when they are perceived as, "1) true to and consistent with what we think we know and what we value, 2) appropriate to whatever decision is pending, 3) promising in effects for ourselves and others, and 4) consistent with what we believe is an ideal basis for conduct" (Fisher, 1987, p. 194). The questions asked are, "Does the story hang together? Is the story free of contradictions?" (Fisher, 1987, p. 88). In other words, do these stories "ring true?" If the answer is yes, it is quite possible that reference to a particular cultural myth will be found in the narrative which provides the foundation for believability and acceptance. The myth is a type of narrative which provides warrants for belief.

\section{Cultural Myth}

Myth can be categorized as a "type" of narrative with its own defining characteristics. Doty, in his book 
Mythography (1986), has constructed a comprehensive definition of "mythological corpus" (body of myths) based on a review of more than 50 definitions. It reads:

A mythological corpus consists of (1) a usually complex network of myths that are (2) culturaliy important (3) imaginal (4) stories, conveying by means of (5) metaphoric and symbolic diction, (6) graphic imagery, and (7) emotional conviction and participation, (8) the primal, foundational accounts (9) of aspects of the real, experienced world and (10) humankind's roles and relative statuses within it.

Mythologies may (11) convey the political and moral value of a culture and (12) provide systems of interpreting (13) individual experience within a universal perspective, which may include (14) the intervention of suprahuman entities as well as (15) aspects of the natural and cultural orders. Myths may be enacted or reflected in (16) rituals, ceremonies, and dramas, and (17) they may provide materials for secondary elaboration, the constituent mythemes having become merely images or reference points for a subsequent story, such as a folktale, historical legend, novella, or prophecy. (1986, p. 11)

While this definition is quite lengthy and too verbose to use on a continuous basis in this study it is valuable in that Doty identifies (with his numbering system) the fundamental characteristics of myth. Robertson's definition is quite similar to Doty's but speaks more to the function of myth in a culture. He writes:

Myths are stories; they are attitudes extracted from stories; they are "the way things are" as people in a particular society believe them to be; and they are the models people refer to when they try to understand their world and its behavior. Myths are the patterns--of behavior, of belief, and of perception--which people have in common... They provide good, "workable" ways by which the contradiction in a society, the contrasts and conflict which normally arise among people, among ideals, among the confusing 
realities, are somehow reconciled, smoothed over, or at least made manageable and tolerable. (1980, p. xv)

Bennett writes that, "In the process of growing up in society most people encounter hundreds of myths that gradually slip into their subconscious thinking" (1980, p. 168). He argues that myth functions as a "code" for reality. Objective assessment or definition of reality is limited by the availability of various myths that can be used as a basis for defining and interpreting a situation (Weaver, 1976). In other words, our perceptions of reality and our confidence in the accuracy of those perceptions are based on a spontaneous adherence to myths and their inherent values.

In our day-to-day experiences we often find ourselves exposed to heroes via re-enactments of cultural myths. Myth scholars tell us that every culture has its myths which guide perceptions and behaviors (Bennett, 1980; Breen \& Corcoran, 1986; Rowland, 1990b; Rushing, 1986). A review of literature relating to myth and mass communication indicates that the use of myth in electronic and printed news reporting is a common occurrence (Bennett, 1980; Breen \& Corcoran, 1986; Fisher, 1973; Nimmo \& Combs, 1982; Rushing, 1986; Smith, 1979; Sperry, 1981).

A 1979 study conducted by Smith suggests that modern myth found in the news (Smith focused on television) is primarily composed of individuals who are every bit as 
powerful as the ancient Greek gods and medieval demons. For example, as we shall see later in this study, it is not logical that Mandela can single-handedly end apartheid and bring peace to South Africa and yet the heroic qualities he is reported to possess by some, suggest otherwise.

Rushing claims that because myth is a type of narrative it lends itself well to pentadic analysis (1986, p. 270). We can focus on the identification of key elements in the myth and the relationships of those elements with others in the text. As with other texts we examine the ratio of tension between elements in order to formulate conclusions regarding motives.

According to Larson (1989), cultural myths underlie a culture and society and can have persuasive appeal. It is my opinion that the persuasive aspects of cultural myths, when woven throughout media narratives, can be an effective means to guide public beliefs and actions. Larson describes cultural myths as "fantasy forms of deep enduring values that most Americans hold" and believes that, "every culture has its own myths and heroes who do things valued by the culture" (1989, p. 224). For example, Larson has used the term "possibility of success" to identify a commonly held American cultural myth which emphasizes the value of hard work, honesty, law and order, sincerity, and faith in the future $(1989$, p. 225). This myth implies that the individual who subscribes to these values will prosper. 
CRITICAL METHODOLOGY

As Malcolm Sillars asserts, criticism is a process in which the scholar "seeks to make an argument that interprets and/or evaluates the messages to which the individual or society is exposed" (1991, p. 2). Significantly, Sillars' discussion of criticism begins with the critic rather than procedure. Since criticism "is not an activity that can be described once for all times and person" the critic, with her particular perspective, becomes the primary method in critical research $(1991$, p. 2). The critic, through immersion in the material of analysis, and through detailed familiarity with conceptual and theoretical tools for framing understanding, is equipped to shed light upon the factors affecting social meaningfulness. Social meaningfulness itself can be viewed diversely. For example, for one critic, news stories focusing on Mandela and South Africa may speak to media interest in promoting the foreign policies of the power elite in the U.S. For another critic the stories may serve as frames for unresolved racial tensions in the U.S.

Additionally, while the critic's tasks involve description, interpretation, and evaluation, these terms themselves, are open to a variety of meaning and emphasis. Brock, Scott, and Chesebro state that although one term/dimension may dominate, "these dimensions tend to merge 
into one another. Each shapes the next and reflects back on the other" (1990, p. 16).

Description raises questions of the scope and detail of the criticism: Description of what? At what level of precision? Contextualized how? And by what? Interpretation, often the heart of critical inquiry, begins with questions of whether the critic will focus upon manifest content of the "text," or whether focus will be on the connotative meanings (latent) in the text. As Sillars notes, one primary distinction by which modes of critical analysis can be organized is whether they are rooted in an objectivist perspective or a deconstructive perspective. Objectivist criticism is often referred to as "common sense" criticism since the critic is primarily concerned with applying "common standards of accuracy, beauty, or effectiveness" to assess the "manifest features of a message" (Sillars, 1991, p. 10). Conversely, deconstructive criticism, which is based on an assumption "that the world as humans know it is defined by the language they use to explain it, "dissects the text to discover "implicit features of messages and understand the ways in which those features govern humans' communicative experiences" (Sillars, 1991, pp. 10-11).

Finally, evaluation can be viewed in a number of ways. Judgments of the text can be made in terms of preestablished criteria (e.g., neo-Aristotelian), judgments in terms of culturally contextualizing factors (e.g., genre 
criticism), or judgments in terms of how the text functions to perpetuate preferred modes of "reading" or understanding the world (e.g., ideological criticism).

This critical-interpretive study seeks to offer an explanation which accounts for the outpouring of welcome Nelson Mandela received from the American public upon visiting the U.S. in June, 1990. My analysis will be of news reports taken from previously-defined mainstream U.S. newspapers for the period 1985 to June, 1990.

Analysis will be grounded in the general theoretical perspective of dramaturgy. Dramaturgy and dramaturgical are terms popularized by Gronbeck (1980) which are used to categorize various drama-oriented approaches to criticism (Brock et al, 1990). Similarly, Sillars (1991) views the dramaturgical perspective as the broad, organizing term under which are found the related strains of Narrative Theory, Burke's Dramatism, and Bormann's Symbolic Convergence Theory. Since it is not my intent to conduct a formal narrative analysis, or Burkean Pentadic analysis, or Fantasy Theme analysis, I shall be drawing upon the key terms of these related approaches to criticism for their value as sensitizing concepts. Of the three related approaches, narrative theory is the most diverse and fragmented, since narrative has been studied and written about by scholars throughout the humanities and social sciences. Specifically, I shall be drawing upon walter 
Fisher's contribution to that general body of work, which is known as the Narrative Paradigm.

Criticism is an activity whose procedures defy strict linearity. As Sillars (1991) states and Brock et al (1990) advise: The closest the critic can come to specifying procedures in advance is to provide an overview of the kinds of questions that the critic will bring to the analysis of the text at the outset. Since continued immersion in that text can lead to the dismissal of early questions, or to their refinement or extension, or to the inclusion of new questions, "procedures" can only be discussed generally. As I begin my analysis of news stories, I shall be guided by two sets of questions. First, and especially in view of the comparatively unproblematic matter of description, I shall be guided by RQ \#1 which asks how the public persona of Nelson Mandela evolved in the dominant U.S. print media (See p. 13). To answer this question I shall be focusing upon manifest content, to characterize and draw inferences as to the nature and development of Mandela's public persona. The other research questions will require more of a concern with the culturally-based, rhetorical foundations upon which the news stories are developed. Here I shall be guided (at least initially) by the specific tools of Fisher's Narrative Paradigm, Burke's framework of the pentad, and Bormann's taxonomy of Fantasy Theme Analysis. 
Fisher's Narrative Paradigm will lead me to ask these questions of the text: Is there a consistency in the narratives in terms of how individual narratives "ring true" when compared with others? How is this consistency established in both form and content? What labels or terms are used to describe Mandela? Do these vary over time? If there are any inconsistencies or contradictions in the news narratives, how do they challenge the integrity of the narratives?

Burke's framework of the pentad will lead me to ask these questions: Which element(s) of the pentad are featured in the news stories? Do the featured elements change with time? If so, how? What is the relationship between the featured elements? How do these elements contextualize each other? How does the featuring of particular elements aid the reader in identifying with and understanding the point of the narrative?

Bormann's taxonomy of Fantasy Theme Analysis will lead me to ask these questions: Do the news stories include or make reference to traditional American myths? If they do, what value systems can be identified? How do these myths and value systems contribute to the development of Mandela's public persona?

The presence of cultural myths and values can be discovered by examining the narratives for the presence of terms used to articulate both positive and negative values, 
and belief statements. Positive value terms identify what is preferred and negative value terms represent the opposite of the preferred (Sillars, 1991). For example, using the word "freedom," in the appropriate context, is an explicit positive value term. However, the value placed on freedom may be implied with the use of a negative value term such as "slavery." Identifying the use of these types of words will assist us in discovering the presence of or reference to cultural myths in the media narratives.

Belief statements make indirect or implicit reference to values (Sillars, 1991). For example, in the following message we are told that South Africa's President de Klerk believes that Mandela's release will help end the racial violence in their country.

President Frederik W. de Klerk announced Saturday that 71-year-old Nelson R. Mandela, who personifies nearly a century of black struggle to end white minority rule, will walk free today after more than 27 years in prison, putting south Africa on a dramatic new course toward ending one of the bloodiest racial conflicts in history. (Kraft, 1990a)

The values implied in the above belief statement are:

freedom and peaceful change are desired states, and violence is a negative or an undesirable state.

In a review of literature on myth I found that a variety of labels have been used to identify some fundamental (or versions of) American myths. For example, Larson's (1989) "Wisdom of the Rustic," Bennett's (1980) "Liberty Myth," and Reich's (1987) "Triumphant Individual" 
all identify a fundamental myth that emphasizes individual freedom, hard work, perseverance, dedication, etc. In an effort to avoid confusion I will use Larson's labels since they reflect a compilation of a variety of terms used by scholars. I will use sillars (1991) description of major U.S. value systems. Sillars has identified six American value systems based on an examination of the work of various "literary historians, intellectual historians, philosophers, rhetoricians, and sociologists" (1991, p. 137). I do not expect to use all categories of myth and value systems, but will choose only those that enhance our understanding of Mandela's public persona.

The period focused on in this study is from mid 1989 to June, 1990, which covers Mandela's release from prison and the period immediately prior to his visit to the United states. Recall that it is within this time frame that we see the emergence and characterization of Mandela's new persona. This study involves a review of over 100 articles from the newspapers mentioned above.

In the following section, Chapter III, I conduct a brief review of the historical/political background of Nelson Mandela and apartheid policy, and mainstream media coverage of Mandela and South Africa's system of apartheid. Additionally, this chapter includes a review of news stories on Mandela prior to mid 1985. 
My review of the history of Mandela, the African National Congress (ANC), and the struggle against apartheid will be brief, considering that it spans a 46 year period. However, events prior to Mandela's release provide a historical background for the ensuing news stories and enable us to create a context within which more recent narratives can be meaningfully interpreted. 
CHAPTER III

HISTORICAL REVIEW OF NELSON MANDELA
AND APARTHEID POLICY

INTRODUCTION

This chapter provides a brief overview of Nelson Mandela's life prior to his release from prison in February, 1990. Included is a historical background of the policy of apartheid, and political, social, and economic conditions in South Africa as they relate to Mandela's struggle. The chapter also contains a brief review of the historical trends of mainstream U.S. media coverage of Mandela and South Africa from 1964 to 1990. The purpose here is to provide the reader with a general overview of the degree to which the American media reported on Mandela. This historical information is necessary as it provides a context for the interpretation and evaluation of more recent news narratives, for as Fisher states, "no text is devoid of historical, situational, and biographical context" (1987, p. 144). I conclude this chapter with the introduction of the concept of "master narrative." 
NELSON MANDELA AND APARTHEID POLICY

Born in 1918, Nelson Mandela was one of 23 million black South Africans destined to live under the domination of apartheid (Blanpied, 1986; Moritz, 1984). As a result of the 1948 elections, the National Party gained control of parliament and created a constitution and set of laws that increasingly excluded the black African majority from participation in the democratic process. Apartheid has been defined by Tatum as: "South Africa's economic, political, and social system which is based on race" (1987, p. 3). In South Africa the white minority, amounting to 16.2 percent of the population, holds a monopoly of the power in the country's parliamentary system that excludes persons of color from full citizenship and participation (Blanpied, 1986). Tatum writes that apartheid is "one of the most pervasive and oppressive systems the world has known because it disfigures humans spiritually as well as physically, the oppressors as well as the oppressed" (1987, p. 3). The South African struggle is a political struggle for a free and nonracial democratic society, led by the ANC.

Nelson Mandela's educational pursuits and political interests eventually led him to become involved in the African National Congress (ANC) at the age of 26. In 1944 Mandela, along with his friends Walter Sisulu, and Oliver Tambo became a member of the ANC, the oldest and most recognized organization resisting white minority rule and, 
eventually, the policies of apartheid. ANC goals were to develop unity among the various African peoples using persuasion and non-violent means to fight for rights of Africans (Peterson, 1971). Later in 1944 Mandela, Sisulu, Lembede, and Tambo formed the Congress Youth League. The aim of the League was to:

...stimulate development of a powerful national liberation movement; African nationalism would be its creed. Their goal was true democracy and to achieve this the League would struggle for the removal of discriminatory laws and the admission of Africans to full citizenship so that they would have direct representation in parliament. (Benson, 1986, p. 29)

Prior to 1948 the ANC and the Youth League engaged in passive, non-violent protest against racial discrimination and segregation. But 1948 ushered in a new era of racial bigotry in South Africa as racial discrimination became more fixed in law. That year the National party won the majority of seats in Parliament and "...white domination and segregation were codified into a statutory system: Apartheid" (Benson, 1986).

In 1952, after serving for a year as the president of the Congress Youth League, Mandela became president of the Transvaal branch of the ANC and deputy national president under Albert Luthuli, a Nobel Peace Prize winner (Moritz, 1984). In addition he was the volunteer-in-chief of the 1952 Defiance Against Unjust Laws Campaign. Mandela's role in the campaign was to travel to townships explaining the Campaign's plans and inspiring people to join in non-violent 
protests against apartheid. The campaign involved a series of peaceful demonstrations throughout South Africa over a six month period. The demonstrations and sporadic rioting resulted in the arrest of over 8,000 blacks and fourteen deaths. During this time Mandela and 51 other leaders and organizers were "banned." Banning was a policy engaged in by the government which severely restricted the activities of individuals. Banning prohibits a person from attending and/or speaking at public gatherings, being quoted, or entering educational institutions, publishing houses, and courts. Banning restricts not only where a person is allowed to travel, but the times at which they can be away from home. Banning orders usually restrict the number of people a banned person may be seen with at one time (Tatum, 1987).

In November, 1952 Mandela was arrested, tried, and found guilty of "statutory communism" (Benson, 1986, p. 50). He received a suspended sentence for two years on the condition that he not repeat the offense (Benson, 1986). The ban was continually renewed until 1961.

On December 5, 1956 Mandela, along with Sisulu and Tambo, and over 150 others, was arrested and "charged with violating the Suppression of Communism Act by plotting to set-up a Communist government and violate apartheid" (Peterson, 1971, p. 41). Mandela's trial began in August, 1958 and lasted until March, 1961 at which time Mandela, 
Sisulu, and Tambo were found not guilty and released.

Mandela immediately went underground.

Even before Mandela's release, plans were being made for a new initiative to end apartheid, and create a democratic state, which Mandela had been chosen to lead (Benson, 1986). Four days before the trial was over Mandela left Pretoria to attend the All-In African Conference in Pietermaritzburg, South Africa (Benson, 1986). The results of the conference included a demand for,

A National Convention of elected representatives of all adult men and women on an equal basis irrespective of race, colour, creed or other limitation which have sovereign powers to determine a new non-racial democratic constitution for South Africa. (Benson, 1986, p. 98)

A letter was sent to Prime Minister Verwoerd outlining the Conference's demands and threats of country-wide demonstrations and stay-at-home strikes if the demands were not met. Verwoerd ignored the letter and Mandela became a hunted man. He moved about South Africa, disguising himself as a laborer, janitor, garbage worker, or chauffeur in order to escape capture by the police (Benson, 1986; Peterson, 1971). Mandela's ability to elude the police for 18 months caused him to be widely known in South Africa as the "Black Pimpernel" (Moritz, 1984, p. 254).

In June, 1961 Mandela and several others formed Umkonto we Sizwe (Spear of the Nation), an underground paramilitary branch of the ANC, dedicated to committing acts of sabotage and attacking targets symbolizing apartheid or having 
economic value (Moritz, 1984). Mandela and his colleagues had decided it was necessary to resort to violence in their anti-apartheid struggle. This tactic did not include violent acts against people. In a statement made from underground on June 26 Mandela expressed his dedication to the struggle.

I shall fight the government side by side with you until victory is won. What are you going to do? will you come along with us, or are you going to cooperate with the government in its efforts to suppress the claims and aspirations of your own people...Remain silent and neutral in a matter of life and death to my people, to our people? For my own part I have made my choice. I will not leave South Africa, nor will I surrender. (Benson, 1986, p. 105)

Early in 1962 Mandela left South Africa to meet with Ethiopian Emperor Haile Selassie and a host of African leaders. There he addressed the Pan-African Freedom Conference. It was the first time Mandela had lived as a "free man."

After touring several African countries Mandela went to London where he met with Labour and Liberal party leaders. On August 2, 1962, only weeks after returning to South Africa he was captured by South African police. On August 8 he was charged with inciting African workers to strike and leaving the country without valid travel documents. On November 7 Mandela was sentenced to five years in prison with hard labour (Benson, 1986).

On July 12, 1962 Sisulu and seven other anti-apartheid leaders were arrested and charged with treason. Mandela, who was already in prison, was also charged with treason. Their 
trial, known as the Rivonia Trial, lasted seven months. In June, 1964 Mandela and seven others were found guilty and sentenced to life in prison.

Although Mandela was silenced by his imprisonment he was certainly not forgotten by his family, friends, and followers. Information regarding Mandela was communicated to the outside world via other prisoners, when they were released, and his wife Winnie who was allowed to visit him once a month for half an hour. After 10 years Mandela was allowed visits from his sister, mother, and a few close friends. Each visit was limited to one person at a time and to half an hour. Under constant surveillance, Mandela was allowed to speak only about family matters.

Occasionally articles about Mandela appeared in the foreign press and Sechaba, the official publication of the ANC, which was published in several locations outside South Africa (Moritz, 1984). While in prison he was rarely interviewed (the first was in 1985). He was never photographed. As a declared "non-person" by the South African government, his views were not allowed to be discussed or printed, and his book of articles and speeches, No Easy Walk to Freedom, was outlawed. No material making reference to Mandela was allowed to be printed in South Africa. 
U.S. MEDIA COVERAGE OF MANDELA

An extensive review of The New York Times articles and indexes reveals that during 1964, when Mandela was being tried for treason, the newspaper printed approximately 20 articles covering the trial. These stories were usually printed on or about pages 10 or 12 in the international section of the paper and were limited to one column. The most concentrated coverage consisted of two articles appearing side by side on April 21, 1964 ("African explains role;" "South African Petrel"). The general tone of both articles toward Mandela is positive. He was quoted several times in each article. These quotes and the journalists' writing depicts Mandela as a reasonable, intelligent, rational individual.

Following Mandela's conviction there is a marked decline in media coverage of Mandela during the years 19651984. A review of The New York Times Index and The Wall Street Journal Index showed that after 1964 only one article, published in The New York Times, featured Mandela (Burns, 1978). Although both papers covered events in South Africa during the 60's only one article, found in The New York Times, mentioned Mandela ("Mrs. Mandela," 1967). In this article he was referred to as the African nationalist leader who was convicted of sabotage and plotting to overthrow the South African government. No details or background information was given regarding the circumstances 
surrounding Mandela's conviction. From 1964 to 1984 no articles were found in The wall street Journal which either featured or mentioned Mandela. The Los Angeles Times indexes prior to 1987 were not available for review. This lack of coverage implies that, as a convicted criminal, Mandela did not merit recognition from the U.S. media.

From 1970-71 only two articles were found in The New York Times which mentioned Mandela. In these articles he was referred to as "...imprisoned black nationalist," and "...jailed black nationalist leader," respectively ("Mandela wife," 1971, p. A19; "South Africa," 1970, p. A4). Again, Mandela is identified as a "leader." However, as with the 1967 article ("Mrs. Mandela," 1976) the lack of specific information about Mandela makes it difficult for the reader to form an opinion about the nature of his leadership.

Each year, between 1972 and 1975, The New York Times published an average of 100 to 150 articles relating to South Africa. No cross reference to Mandela was found in the indexes for these years. In 1976 and 1977 a total of seven articles were found which mentioned Mandela. Of these, one named Mandela as a recipient of the 1976 Florina Lasker Civil Liberties award ("4 dissidents," 1976), and another gave a brief, ten-line biographical sketch of Mandela (Burns, 1977a). In both of these articles personal information about Mandela was limited. Again, no mention was made of the circumstances surrounding his imprisonment. 
However, the fact that he was associated with a civil liberties award suggests that his interests were perceived by some as being humanitarian in nature.

Winnie Mandela made front page news in June, 1977. Following Mandela's incarceration, Winnie became a key spokesperson for the black liberation movement. In this article she was referred to as the "first lady of black South Africa" (Burns, 1977b, pp. A1, 8). This phrase implies a formal, quasi-institutional legitimacy. In the article Nelson Mandela was referred to as the, "...jailed nationalist leader." The implication is that if Winnie is the first lady of black South Africa Nelson must be its legitimate head. This is the first time since 1964 that Mandela is depicted as a prominent figure in South Africa. One article in 1978 which featured Mandela on his 60th birthday described him as a "key black leader," but here again the article was very short and detailed information was lacking (Burns, 1978, p. A2). No other articles were found which mentioned Mandela that year. In 1979 Mandela was awarded the Nehru Award (India's highest Civic award) and yet no mention of this was found in the news reports (Meer, 1988).

U.S. media coverage of South Africa increased beginning with the 1980's. A number of factors coincide with this attention: the escalation of violence in South Africa, the anti-apartheid movement's success at focusing attention on 
their cause, continued pressure being put on the Reagan administration for economic sanctions against South Africa, UN Security Council resolutions, home-based protests against apartheid, and the formation of the Sullivan principles, a code of ethical conduct created by the Reverend Leon Sullivan, pastor of Zion Baptist Church in Philadelphia (Lashgari and Gant, 1989). These principles provide guidelines for the promotion of social justice and equality to be used by international and domestic corporations operating in South Africa. International businesses are discouraged from investing in a country which ignored the educational, general welfare, and societal rights of the majority (Lashgari and Gant, 1989).

During the 1980's American newspaper stories focused on the scene in South Africa, economic sanctions, and U.S./South African relations. Between 1980-83 four stories in The New York Times featured Mandela (Burns, 1980; "City College," 1983; "Four die," 1980; "Mandela is transferred," 1982). The majority of other stories which mentioned Mandela featured his wife winnie and her activities in the apartheid resistance (Lelyveld, 1983; 1982; 1981). From 1963 to 1986 Winnie was repeatedly banned and/or jailed on various charges ranging from ban violations to terrorism. Although "banning" restricted Winnie's contact with the world outside her immediate family, reports of her activities, views, and even a few direct quotes were smuggled out of South Africa 
and reached U.S. newspapers. However, we learn little about Nelson Mandela from these stories. For example, "In 1981 a United States Congressional delegation, led by Harold Wolpe requested a visit with Mandela, but were refused" (Meer, 1988, p. 313). No mention of this request was found in the U.S. news reports.

In 1984 more media attention was given to South Africa and the anti-apartheid movement when Bishop Desmond Tutu, a black South African who openly opposed apartheid, was awarded the Nobel Peace Prize (Cowell, 1984; Feder, 1984; Fein, 1984). A review of The New York Times between October, 1984 and April, 1985 shows that coverage of Tutu's Nobel prize award and conditions in South Africa included no mention of Mandela. The focus was on Tutu, South Africa's President Botha, political unrest, and South Africa's religious community's involvement in the anti-apartheid movement. No mention was made of the South African government's offer to release Mandela. This offer was made in 1984 on the condition that Mandela retire to the tribal homeland of Transkei and condemn all violent activity. Mandela rejected the offer. He was not willing to leave prison unless he had the freedom to move about the country and he was not willing to denounce violent resistance to apartheid until the government actively engaged in peaceful negotiations with the ANC (Benson, 1986; Moritz, 1984). 
1985 witnessed a marked increase in the coverage of South Africa and apartheid by the U.S. media. South Africa was experiencing increased international pressure to reform its society and release Mandela. Meer writes,

The world now clamored for the return of Mandela to his people. But it became clear that it was no longer a matter of releasing a prisoner to his family and to private life, it was the return of a national leader to lead the country to a new society. The Nationalist Government was under severe pressure to change and negotiate a new society. (1988, p. 314)

The average number of such articles published in the New York Times were approximately one per week. For example, on April 24, "National Anti-apartheid Day," thousands of college students across the U.S. staged protests calling for universities and colleges to end their investments in south Africa (Rohter, 1985). South Africa made the front page of The New York Times in July, when the Senate approved legislation for economic sanctions against South Africa (Fuerbringer, 1985b).

Significant events continued to unfold in South Africa. On August 15, 1985 President Botha delivered a speech to the National party which reaffirmed the government's unrelenting position on apartheid. He stated that he was unwilling to accept a one-man-one-vote system of government. He refused to release Mandela and other political prisoners and he refused to create a fourth chamber in parliament for 
blacks. Responding to international pressure for abolishing apartheid Botha declared:

We have never given in to outside demands and we are not going to do so. South Africa's problems will be solved by South Africans and not by foreigners. We are not going to be deterred from doing what we think best, nor will we be forced into doing what we don't want to.... [To] those who prefer revolution to reform, I say they will not succeed no matter how much support and encouragement they derive from outside sources. (Blanpied, 1986, p. 516)

It must be noted however, that despite Botha's strong words Parliament did institute a series of changes in the apartheid system in 1985. Legislation banning mixed marriages and sexual relationships between the races was repealed. A freehold system of land ownership for blacks was introduced, which would allow blacks to own residences in urban areas. However, blacks would only be allowed to own land in areas designated for blacks. There was also limited desegregation of trains and some other public facilities under a "local option" system (McGovern, 1988, p. 101). This meant that individual facilities had the option of refusing to admit non-whites. Within a few weeks after Botha's speech President Reagan signed an executive order which imposed economic sanctions on South Africa (Gwertzman, 1985b; Weinraub, 1985).

Front page coverage of the above events in The New York Times brought increased attention to South Africa (Fuerbringer, 1985a; Fuerbringer, 1985b; Gwertzman, 1985a; Gwertzman, 1985b; Weinraub, 1985). With one exception, 
reports of Mandela were limited to the back pages of the paper ("Mandela advised," 1985; Dash, 1985). On October 4, 1985 a front page article mentioning Mandela did appear in The New York Times. In the article, Secretary of State George Shultz was reported to have suggested that the South African government ought to release Mandela as a sign that they were willing to negotiate a peace with the black African majority (Gwertzman, 1985a). This was the second time Shultz had called for the release of Mandela, claiming it would be a conciliatory gesture on the part of the South African government. The half page, four column article devoted only four sentences to Mandela. The article focused on Shultz and his criticism of apartheid and other international matters.

Social unrest in South Africa was not getting better, it was getting worse. It has been estimated that during 1984-85 ". .843 people died because of political unrest, and almost 11,000 persons were detained during the year" (McGovern, 1987, p. 101). On July 21, 1985 a state of Emergency was declared in 36 of South Africa's 265 magisterial districts. This state of Emergency was extended in June, 1986 and then again in June, 1987. In November of 1985 all media was banned from reporting on events in areas under a state of emergency (McGovern, 1987).

The South African government needed to take some action which would send a message to the international community 
that efforts were being made to bring about a peaceful end to the unrest. One such action was to lift some of the restrictions on who was allowed to visit Mandela in prison. Regardless of the underlying motives of those involved, increased visitation rights for Mandela resulted in a rare interview with Mandela by an American (Dash, 1985). Although the interview did not make the front page of The New York Times it is significant because it was the first article printed since 1964 in which Mandela was directly quoted. In reference to the civil unrest in South Africa Mandela stated,

If white leaders do not act in good faith toward us, if they will not meet with us to discuss political equality and if, in effect, they tell us that we must remain subjugated by the whites, then there is really no alternative for us other than violence. And I assure you we will prevail. (Dash, 1985, p. F21)

In 1986 leaders of the Commonwealth of Nations (49 English-speaking countries, including Zimbabwe, Botswana, and Zambia) commissioned a seven-member Group of Eminent Persons to "facilitate political dialogue in South Africa" (McGovern, 1987, p. 581) in an attempt to end apartheid and establish a non-racial representative government. The group's final report, after six months of study, was quite pessimistic. The report, titled "Mission to South Africa," (McGovern, 1987, p. 581) among other things, urged countries around the world to adopt economic sanctions against south Africa in an attempt to force the government to negotiate 
with anti-apartheid leaders for a peaceful end to apartheid. The group had been allowed to meet with Mandela on three occasions in March and reported that it was their opinion that he was essential to any political settlement.

These were the first political visits Mandela had been allowed in over 20 years. The report described Mandela as follows :

He impressed us as an outstandingly able and sincere person whose qualities of leadership were self-evident. We found him unmarked by any trace of bitterness despite his long imprisonment. His overriding concern was for the welfare of all races in South Africa in a just society; he longed to be allowed to contribute to the process of reconciliation. We all agreed that it was tragic that a man of his outstanding capabilities should continue to be denied the opportunity to help shape his country's future, especially as that is so clearly his own profound wish.... (McGovern, 1987 , p. 587)

Coverage of the visit was found on page 11 of The New York Times (Lelyveld, 1986b). In this article the reader is told:

Although Mr. Mandela, 67 years old, has been removed from active politics for half his adult life, his long imprisonment has conferred on him a powerful symbolic status as the pre-eminent black leader in South Africa. (Lelyveld, 1986b, p. A11)

In 1986 coverage of Mandela increased in The New York Times. On January 8 , an article reported that a U.S. Congressional delegation to South Africa was denied permission to visit Mandela in prison by the South African government (Cowell, 1986b). Here again, as with the shultz article (Gwertzman, 1985a), Mandela's status as an important 
figure is further secured with the announcement that U.S. congressmen desired to visit with him (Cowell, 1986b). The South African government's refusal to grant the congressmen a visit with Mandela, without explanation, suggests that such a visit might give Mandela more attention and support than the government wanted.

On February 1 an article appeared in which President Botha suggested that Mandela might be released if the Soviet Union freed two well-known dissidents, Andrei Sakharov and Anatoly Shcharansky, and Angola freed a captured South African soldier (Cowell, 1986a). Mandela had become a bargaining tool, a pawn in South Africa's political and economic struggle to recapture its previous position in the world market. As journalist Alan Cowell stated,

At the same time, however, the offer seemed to imply a leap in the authorities' own logic, conferring on $\mathrm{Mr}$. Mandela, who is depicted here [South Africa] as a terrorist, the same politicalprisoner status, that is attributed in the West to Mr. Sakharov and Mr. Shcharansky. (1986a, p. A4)

In the same article Cowell mentioned that Mandela and his wife Winnie had been nominated for the Nobel Peace Prize. In May, 1986 a full page article on page three of The New York Times covered the possible willingness of the South African government to legalize the outlawed African National Congress and release Mandela (Lelyveld, 1986a). On July 1, 1986 the paper covered the televising of a documentary on the life of Nelson and Winnie Mandela being aired that same day (Corry, 1986). 
During the late $1980^{\prime}$ s Mandela became a significant public persona for reporters. Even though the South African government had put tight restrictions on the reporting of racial unrest in their country it appears that those in power felt it would be to their advantage to allow reporters to cover negotiations for Mandela's possible release. (Battersby, 1987; "Botha says," 1988). By late 1987 we find Mandela being quoted in U.S. newspapers on a regular basis. A November 8 article in The New York Times quoted Mandela as saying that he would, "bend all his efforts toward a peaceful solution in South Africa if he were freed" (Battersby, 1987, p. A26).

In 1988 Mandela was hospitalized with Tuberculosis ("Botha says," 1988). On August 18 President Botha announced that he was trying to reach an agreement with Mandela regarding his release. Botha is quoted as saying,

Personally, I don't think that at his age and condition, it would be wise for him [Mandela] to choose to go back to prison and I hope he will make it possible for me to act in a humane way so that we can have peace in South Africa. ("Botha says, " 1988 , p. A11)

The implications of this statement are clear. Botha is attempting to cast Mandela in the role of the antagonist and himself in the role of the protagonist. Botha desires to be perceived as the rational and humane peacemaker while Mandela is cast as the stubborn irrational resister. The content of the story reveals an inconsistency in Botha's motives. On one hand, he claims (indirectly in the above 
quote) that he seeks peace in South Africa and yet in the next paragraph he is quoted as saying, "I am not even considering the possibility to discuss black majority government in South Africa" ("Botha says," 1988, p. A11). The article portrays Botha as a stubborn child, "Mr. Botha, apparently stung by demands in South African newspapers for Mr. Mandela's release, said he was not going to be told what to do by the press or by those he called Communists" ("Botha, says," 1988, p. A11). Even though this article makes little mention of Mandela it does cast him in a positive role by casting Botha in a negative one, focusing on the stubborn willfulness of President Botha.

In April, 1989 Mandela was said to have made a plea to black Africans to unite and end three years of fighting between factions of the zulu people (Battersby, 1989). On July 9 front page coverage was given to a meeting of President Botha and Mandela at Victor Verster Prison (Wren, 1989d).

By mid 1989 it began to look as if Mandela would in fact be released from prison. Reports indicated that Mandela had been negotiating with Justice Minister $J$. J. Coetsee and other officials not only for his own release but the release of other political prisoners as well (Wren, 1989d; 1989e). In July meetings between Mandela and Botha were reported and journalists speculated as to who was really in control of 
negotiations for Mandela's release (Wren, 1989e; Thurow, 1989b). Thurow wrote,

Last week, when Mr. Mandela was driven through the prison house gate to the Cape Town home of South African President P.W. Botha, it became clear the government is also a prisoner of Nelson Mandela. For 45 minutes, over tea and cookies, the two old adversaries--Mr. Botha was once quoted as saying Mr. Mandela could 'rot' in jail--talked about the need for bringing peace to this racially divided country.... But one conclusion is inescapable: the government, desperate to improve its international image and resolve its internal conflict, needs the cooperation, and freedom, of Nelson Mandela. (Thurow, 1989b, p. A16)

On September 6, 1989 F. W. de Klerk was elected president of South Africa. Promises of "a totally changed South Africa...free of domination or oppression" (Gimin, 1990, p. 545) greeted South Africans on September 20, 1989 when de Klerk delivered his inaugural address. As he spoke, his country was in the midst of turmoil from a campaign Iaunched by the Mass Democratic Movement protesting the exclusion of blacks from voting on election day (Moritz, 1990)

Even though a state of emergency was still in existence, a few days after the election de klerk announced that peaceful demonstrations would be allowed. Subsequently two protests were held in Cape Town and Johannesburg without incident (Moritz, 1990).

South Africa and Mandela were front page news. On October 11 it was announced that de Klerk had authorized the release of eight prominent political prisoners ("Black 
leaders," 1989). That day 70,000 people gathered at a rally near soweto in celebration of the prisoners release. Mandela was not released. An October 16 article focused on a news conference held by these ex-prisoners in which a plea was made for the release of Mandela (Wren, 1989b). On December 13 Mandela met with President de Klerk to discuss the future of South Africa and his release (Wren, 1989a). And finally, in January, 1990 the announcement came that Mandela would be released (Burns, 1990a).

\section{SUMMARY}

Prior to 1985 , coverage of Mandela was so sketchy and vague that it contributed little to the development of his public persona. Beginning in 1985 reports of Mandela not only increased, but the nature of those reports began to change. As media gave more attention to Mandela, a public persona began to develop, which by 1989, embodied the ideals and values of Western democracy.

As indicated in Chapter $I$, there are two distinct phases which occur in the development of Mandela's public persona. During the first phase Mandela's role in the news reports progressed from minor to major character. He becomes a co-actor, along with various South African and U.S. officials, in the South African scene. Eventually, as news coverage reveals more about Mandela's character, actions, hopes, and dreams, Mandela becomes the central actor in the 
reports. These matters are explored in Chapter IV. The second developmental phase of Mandela's persona (Chapter V) marks a period when Mandela actually becomes the scene. Rather than being an actor "contained" within a scene, he becomes the "container," the scene, in which all other elements of the narrative are contained (Burke, 1962, p. 3). Mandela becomes the symbolic representation of the dreams, hopes, struggles, and fears of millions of black south Africans. Chapter $\mathrm{V}$ focuses on these matters.

The "master" narrative of Nelson Mandela as found in U.S. news reports is a compilation of individual news reports. These reports, which give an account of reality, have at their core, a moral message or dimension (Fisher, 1984; White, 1981) which accounts for the expressed beliefs and actions of the characters in the news reports. At the core of the master narrative, during the period from 1985 to June, 1990, resides the moral dilemma of the eternal struggle of good over evil. The implication is clear: Equal rights for all South Africans must replace the evil system of apartheid.

The individual stories which constitute the master narrative contain a variety of themes. Many deal directly with issues of equal rights and a free society, while others focus on political and social change, foreign relations, and economic recovery for South Africa. However, all of these stories, taken together, contribute to the central theme of 
good vs. evil. For example, in Thurow's (1990g) article the reader is introduced to the theme of an improved economic climate in South Africa with the pending release of Mandela. In this article almost sole responsibility for a sharp rise in the Johannesburg stock exchange is given to Mandela.

This is no ordinary bull market. It is a Mandela Market; As expectations of his release and other political reforms soar, so does the country's business confidence... the market's Mandela index indicates that things are looking up. (p. A12)

In this same article Neil Czypionka, chief economist at Standard Bank in Johannesburg, was quoted as saying, "Mr. Mandela's release is one milestone in the process of reform. It is a means to an end" (Thurow, 1990g, p. A12). Mr. Czypionka is referring to an end to apartheid. Good, he says, will eventually win out over evil.

Traditionally, critics use Burke's pentad to discover the ways in which various elements of a story connect to one another and their relationship (Sillars, 1991). However, while the critic must examine each and all elements for meaningful interpretation, the focal point of analysis usually centers on those elements that dominate and overlap, those elements that exhibit the strongest tension between them. Doing so results in identification of what is referred to a "central ratio" (Sillars, 1991).

When a critic uses Burke's pentad as a tool for examining a text, she will find that one or more elements of the text will be highlighted or featured. When studying the 
news reports of Mandela I found that scene, agent, and purpose, in various combinations, were the primary elements featured throughout the stories. My primary concern then is with these three elements.

The master narrative of Mandela is played out in media reports, not in lieu of other reports of South Africa, but in conjunction with these reports. This master narrative of Mandela is the focus of the remaining chapters.

\section{PREVIEW OF CHAPTER IV}

In Chapter IV I will describe the development of Mandela's public persona from 1985 to mid 1989 and discuss new narratives in terms of how they function as guides to belief and action. 


\title{
WINDS OF CHANGE-- \\ THE PUBLIC PERSONA OF NELSON MANDELA \\ 1985 TO MID-1989
}

\begin{abstract}
"I left Mandela on the sun-washed rooftop, tending his garden, and waiting, as he has for nearly a quarter-century, for a chance to lead the nation that now imprisons him."
\end{abstract}

$$
\text { ...Dash, } 1985
$$

\section{MASTER NARRATIVE}

From 1985 to mid-1989 the master narrative found in U.S. print media concerning Mandela placed him in a country that was on the verge of monumental change. Civil unrest in South Africa continued. The South African government was experiencing increased pressure from the international community to rewrite completely its constitution to provide for the full political participation and rights of all south Africans.

The media initially cast Mandela in the role of a nonparticipant in South African affairs. Gradually Mandela came to be portrayed as an instrument of change with the speculation of his possible release. As this period progressed the media bestowed on Mandela the role of agent/actor by associating him with prominent political 
leaders in both South Africa and the United States. Incorporated in this progression was the introduction of Mandela, to the readers, as a hero (a legend) to black South Africans.

The master narrative of this period concludes on a note of suspense: Will Nelson Mandela be released from prison, and will he be allowed to participate in the changes that appear to be inescapable?

As we have seen in the previous chapter, there has been a gradual change in the form and content of news reports about Nelson Mandela spanning a 26 year period. Prior to 1985, sporadic reference to Mandela dealt strictly with the selective reporting of facts, taken to be truths. Reference was made to Mandela's status as a prisoner, why he was convicted, and his role in the ANC. These reports centered around current events in South Africa and international relations. Mandela provided an example, to be used by the media, of the oppression of apartheid. He was one of many whose natural rights had been denied. But between 1964 and 1985 Mandela was never portrayed as a particularly important figure in the South African scene. However, in 1985 we begin to see the gradual evolution of a body of narrative in which, by 1989, Mandela comes to be the principle element. As stated earlier, 1985 witnessed a marked increase in news reports of South Africa. Even though few articles were published which focused on Mandela, this year is important 
because Mandela's role in the news reports began to change from that of merely one element of the larger South African scene to a distinctive agency of change in a master narrative which was dominated by the political and social scene in South Africa. Three 1985 articles centered on Mandela (Cowell, 1985b; Dash, 1985; "Mandela advised," 1985) and one which made reference to him (Gwertzman, 1985a). Seven articles in 1986 and 1987 centered on Mandela, six of which used his name in the headline (Battersby, 1987; Cowell, 1986a; Cowell, 1986b; Corry, 1986; Farber, 1987; Lelyveld, 1986a, Lelyveld, 1986b). Two of these were reports on a television documentary on the lives of Nelson and Winnie spanning a 30 year period (Corry, 1986; Farber, 1987). Only two articles featured Mandela in 1988. But from January, 1989 to July, 1989 ten articles relied upon Mandela as their key subject.

This chapter describes the evolution of Mandela's public persona from 1985 to mid-1989. It then evaluates the news reports in terms of how they function to establish Mandela as a hero, and how these reports serve as guides to belief and action for the reader.

\section{EMERGENCE OF THE MASTER NARRATIVE}

From 1985 to mid-1989 news reports which mention and/or feature Mandela were contained within a scene that depicted a country embroiled in social and political turmoil. The 
system of apartheid dominated the scene and was characterized as the controlling force for the actions of the characters in the stories. For example, Gwertzman's (1985a) article which reported a request for Mandela's release, made by Secretary of state George Shultz, highlighted the fact that apartheid laws and restrictions (i.e., moral conditions) were directly responsible for continued acts of violence in South Africa and strained relations between the South African government and the U.S. And Cowell's (1986b) article, headlined "Americans Barred From Seeing Mandela" reported that during an American delegation's visit to South Africa five blacks were killed by police in two separate confrontations with black protestors. The article also told of black protestors who delayed the reopening of black schools, and strikes by black mine workers. Battersby's article (1989) reported that over a three year period (1986-89) over 1,400 people died in factional fighting.

As this period (1985 to mid-1989) progresses, attention shifts from scene to agent with emphasis placed on the actions of key political figures contained in the scene. Continual reference is made to the system of apartheid which focuses the reader upon apartheid as the root of the majority of South Africa's problems.

The media provided a physical setting for the development of Mandela's persona not only within the 
newspaper pages but also in the political/social scene of South Africa. Adhering to standard journalistic conventions, lead paragraphs featured Mandela, but always in relation to his status as a prisoner of South Africa, and/or the social/political scene. For example, in his opening paragraph, Cowell wrote,

President P. W. Botha in a speech in which he promised changes in South Africa's racist policies, suggested today that the jailed black nationalist Nelson Mandela might be freed if the Soviet Union released two well-known dissidents and if Angola liberated a captured South African soldier. (1986a, p. A4)

The reference to Mandela in lead paragraphs, along with using Mandela's name in headlines, and arranging these news reports on the same page(s) with other reports on South Africa functions to create the impression that Mandela, even though he is in prison, is very much a part of the south African scene. He comes to be portrayed as an instrument, as an agency for change. His release is the means by which conflicting factions can begin to achieve peace. Lelyveld wrote, "...the Commonwealth representatives pressed President Botha to release Mr. Mandela as a step toward negotiations between the Government and the African National Congress" (1986b, p. A11).

In 1987 the idea that Mandela could be a significant participant in negotiations began to develop. Battersby's article, "A Free Mandela Could Aid Peace, Nationalist Tells 
South Africans" (1987, p. A26) quoted Mandela's colleague, Govan Mbeki, as saying that,

Mandela would "bend all his efforts" toward a peaceful solution in South Africa if he were freed....

Mbeki reported that Mr. Mandela was "greatly concerned" about the situation in the country. Mr. Mbeki said: "He is not taking a propagandistic stance in his assessment of the situation in the country and in the search for a solution. He does not see his release as something that would give rise to anything other than helping the resolution of the problems." ((Battersby, 1987, p. A26)

statements such as this aid in solidifying Mandela's personal desire to participate in a restructuring of his country's political system with the speculation as to his role in South Africa's future.

Headlines and opening paragraphs associated Mandela with prominent figures in both South Africa and the U.S. For example:

"Pretoria Links Mandela's Fate to Soviet Dissidents" (Cowell, 1986a, p. A4)

"Shultz Suggests That South Africa Release Mandela" (Gwertzman, 1985a, p. A1)

"Americans Barred From Seeing Mandela" (Cowell, 1986b, p. A3)

"Envoys Break New Ground In Mandela Visit" (Lelyveld, 1986b, p. Al1)

In each of these articles Mandela's import was enhanced when readers were told that the U.S. government, an American delegation (consisting of several congress men and women), and a Commonwealth delegation were all lobbying for Mandela's release. 
The central theme found in the majority of news reports during this period was change, change in the form of political cooperation and compromise, improved political and economic relations, and equal rights. The need for change in the existing scene was the central purpose for which the actions of the characters in the scene were justified.

Burke notes that as one element of the pentad changes we can expect pressure to be exerted on other elements to also change. He writes that, "It is a principle of drama that the nature of acts and agents should be consistent with the nature of the scene" (1969, p. 3). Media reports indicated that the scene in South Africa was ripe for change. The form of this change was yet to be determined and depended a great deal on the attitudes and actions of the country's key politicians. Will there be a violent revolution or a negotiated peace? The news reports suggested that the inevitability of change was exerting a pressure on key actors to modify their attitudes and actions. One indication of this pressure was the reference made to Mandela's possible release. Lelyveld wrote,

A Commonwealth delegation appears to have broken new ground on a visit to South Africa by meeting with the black nationalist leader Nelson Mandela.

The meeting was the first such diplomatic contact that $\mathrm{Mr}$. Mandela has been permitted in the 23 years he has been in prison, and it seemed to represent a tacit recognition by the South African Government of his status as a political leader [italics added]. (1986b, p. A11) 
Lewis' article was very explicit in outlining, for the reader, situational pressures which would inevitability require co-agents/actors to adjust their attitudes and behaviors. On an international level Lewis told readers that the South African government had accepted an Americanmediated agreement to get Cuban and South African forces out of Angola and free Nambia, an action which resulted in a decrease in military influence inside South Africa. Lewis wrote,

Over the years Mr. Botha claimed that South Africa faced a "total onslaught" from international Communism. That was justification [italics added] for brutal internal repression. But now the Cubans are going. (1989, p. E25)

In reference to internal pressures for change Lewis told readers that there had been a shift "at the top" in South African politics. He expected to see policy changes from $F . W$. de Klerk, who had replaced Botha as the National Party leader, and who would probably become South Africa's new president (p. E25). However, Lewis indicated that even though he did not expect the South African government to abandon its system of Apartheid anytime soon, internal pressures could not be ignored. He wrote that the real issue facing South Africa was the right of all South Africans to vote. He reported that the number of skilled black workers and customers in Johannesburg was growing, and that these "middle-class blacks" were experiencing increasing anger when apartheid laws forced them to live in Soweto slums 
(p. E25). Lewis concluded his article by claiming that the only solution to these "situational" pressures was negotiation. The South African government had to begin negotiating with the black populace. And who should sit at the negotiating table as a representative of this populace? Nelson Mandela.

Again and again news reports made reference to existing apartheid policies and implied that those policies had to be changed. In fact Cowell described South Africa as a "nation in crisis" which would continue to experience racial violence unless the government relaxed its apartheid policies and sought peaceful negotiations with its black population (1986a, p. A4). In Gwertzman's article (1985a) Secretary of State George Shultz is quoted as saying that,

Apartheid is through.... It doesn't matter whether you think Apartheid is a good idea or not, it's going to disappear. Now the question is how do you manage the transition.... If it [the transition] isn't addressed, we can have a cycle of continued violence and at least one can readily imagine this blowing up into a really violent upheaval. (1985a, p. A1)

This statement, prefaced by an opening paragraph which described Mandela as a "prominent black political prisoner" with whom President Botha should be negotiating, set the stage for the introduction of Mandela as an agent/actor in bringing peaceful change to South Africa.

As the number of articles featuring Mandela increased, the central theme of change, woven throughout the news reports prompted predictions as to Mandela's role in 
bringing change to South Africa (Battersby, 1987; Cowell, 1986a; Gwertzman, 1985a; Lelyveld, 1986a; Lelyveld, 1986b; Wren, 1989d; "Yes to Mandela's,". 1989).

Mandela's character was developed as the readers learned more about his personality, his beliefs, his struggles, and his dreams and hopes for the future of South Africa. Supporting characters were developed through their associations with Mandela and their role in the changing scene.

In sum, the master narrative, during this period, was developed around the concept that change in South Africa's political and social scene was inevitable, and that Mandela's release was a necessary prerequisite for peaceful change.

The following section provides a detailed description and evaluation of individual narratives which justifies this construction of the master narrative.

\section{NELSON MANDELA'S PUBLIC PERSONA}

Media stories, which featured Mandela, established a consistency between the changing scene and its key agents/actors by involving Mandela in the scene. Consideration of Mandela's release was used as a means of demonstrating the government's willingness to consider making changes. But who is Mandela? And why should his release be an issue? After all, he was convicted of treason 
and conspiracy to overthrow the government. Initially it does not make sense that a convicted criminal should be released at a time when South Africa was experiencing a high degree of civil disobedience by his followers.

Fisher claims that narratives come to be accepted by a reader if they provide "good reasons" for acceptance of that particular narrative. Reasons are good if, among other things, they are perceived as "true to and consistent with what we think we know and what we value," and if they are "consistent with what we believe is an ideal basis for conduct" (1987, p. 194). For narratives to be believed they must "hang together," they must "ring true" for the audience. The task for the journalist then is to demonstrate a consistency between previous news reports and/or account for any inconsistencies that may cause the reader to question the credibility of the story. They must supply the reader with "good reasons" for accepting the story.

This task is not a particularly difficult one since previous coverage (prior to 1985) of Mandela was so limited and vague. Journalists began to supply "good reasons" for public consumption when they introduced Mandela as a "legend" among millions of black South Africans. The media reports sought to answer the above questions and resolve a potential paradox by developing Mandela's persona in a way that bestowed on him the qualities of a peaceful hero and 
hence sought to cancel any negative imaged readers might have had of Mandela.

The Dash (1985) and Cowell (1985b) articles provided a dramatic illustration of the change which began to occur in both content and form of the news reports during this period. Both articles appeared on the same page and Cowell's included a photo of Mandela, who appeared to be sitting on a cot in a jail cell. Mandela's head was bent and his hands were folded. The image is that of a quiet, peaceful man, perhaps a "beaten, broken" man. As illustrated by the headlines ("The man nobody knows," and "A rare talk with Nelson Mandela,") Cowell and Dash literally introduced the reader to Mandela.

In his article, Cowell focused on Mandela's background and his connections with the ANC. This article was particularly enlightening because Cowell revealed the degree of "fame" and "legendary" status attributed to Mandela. He wrote,

During his confinement, Mandela's fame has grown into legend, assuming an almost mythical importance in the litanies of the nation's defiance. Yet he is visited regularly only by his family, and he remains unseen by his millions of supporters.... No stigma of compromise or doubt is attached to his name. And his fame has spread not only throughout Africa, but also to countries such as England....(1985b, p. F22)

Cowell also told readers that in early 1985 President Botha had offered to release Mandela if he would renounce the violent activities by some ANC members. Mandela refused 
on the grounds that, "I cannot and will not give any undertaking at a time when $I$, and you the people, are not free. Your freedom and mine cannot be separated [sic]" (Cowell, 1985b, p. F22).

Dash's article linked Mandela's past to the future of South Africa. Recall that Dash's interview with Mandela was the first article printed since 1964 in which Mandela was directly quoted. The published interview provided the general public with an image of Mandela that had been lacking in earlier news reports. Dash portrayed him as a martyr, a champion of human rights, and a hero. Included in the article were Mandela's views regarding the prospects for peaceful co-existence between blacks and whites in South Africa. Dash told his readers that Mandela was very knowledgeable about current affairs in South Africa and the world despite his confinement. Also included was Mandela's outline of a program that he and the ANC felt must be implemented by the government if peace is to be realized. The program called for, "a unified South Africa--no artificial homelands, black representation in the central parliament... and one man, one vote" (1985, p. F22). Through the inclusion of Mandela's own words Dash portrayed Mandela as a man who desired peace, but was unwilling to denounce violent protests until the government made significant moves 
to change its policies. Mandela demonstrated a strength of character befitting a hero. Dash quoted Mandela as saying,

Unlike white people anywhere else in Africa, whites in South Africa belong here--this is their home. We want them to live here with us and to share power with us....However, if white leaders do not act in good faith toward us, if they will not meet with us to discuss political equality and if, in effect, they tell us that we must remain subjugated by the whites, then there is really no alternative for us other than violence. And I assure you we will prevail. (1985, p. F22)

Dash's physical description of Mandela, coupled with the photo accompanying Cowell's article, gives the impression that Mandela was displaced. In other words, he did not fit the sterotypic image of a prison inmate who was convicted of terrorism and treason. Dash reported,

He is a tall, slim, handsome man who looks far younger than his 66 years. Dressed in his own well-fitted khaki shirt and trousers, rather than a regulation blue denim prison uniform, he appeared vigorous and healthy, with a calm, confident manner and dignified bearing that seemed incongruous in our prison surroundings. Indeed, throughout our meeting, I felt that I was in the presence not of a guerrilla fighter or a radical ideologue, but of a head of state [italics added]. (Dash, 1985, p. F21)

In this article the reader received a glimpse of the personal side of Mandela's character as well as the political side. Throughout the article Dash made reference to Mandela's appearance, the softness of his voice, and the courteous manner in which he treated the guards.

Dash concluded his article with a description of Mandela which cast him in the role of a savior who was patiently waiting to lead his people out of bondage. 
I left Mandela on the sun-washed rooftop, tending his garden, and waiting, as he has for nearly a quarter-century, for a chance to lead the nation that now imprisons him. (Dash, 1985, p. F22)

Both Dash and Cowell told readers, in no uncertain terms that Mandela was a "legend." In this sense the journalists were playing the role of "teacher" as they instructed their readers (the students) as to how Mandela was to be perceived. This practice continued, in varying degree, from 1985 to June, 1990. However, the above news reports lacked detail as to the actual nature of this legend. Readers would not learn the details of the legend until early 1990. This vagueness served to create an aura of mystery surrounding Mandela and set the stage for the creation of a media celebrity. Recall that Boorstin (1961) posits that the American public expects and demands that newspapers be full of interesting if not exciting news, and the celebrity (the human pseudo-event) is one way of achieving interest and excitement. The media worked to create a dramatic tension in their reports of Mandela; a legend was imprisoned in South Africa and it was rumored that he might be released.

As the above articles illustrate, a tension began to develop between the scene, South Africa with its social and political struggles, and Mandela, as he came to be identified as an instrument of change within the scene. 
From the news reports readers learned that prior to 1985 the South African government had maintained a hard-Iine in the enforcement of apartheid policies, despite both peaceful and violent resistance within their country, and pleas for equal rights for all its people from the international community. If the government had hoped that Mandela's imprisonment would help put an end to the antiapartheid movement they must have been extremely disappointed. Over the years violence and civil unrest had increased. Now, in 1985, according to news reports, the government appeared to be willing to at least consider making some changes in its apartheid policies.

Based on news reports which mentioned and/or featured Mandela, it seems that both U.S. and South African officials viewed Mandela as a vehicle for change. Mandela was cast in the role of a "bargaining tool" to be used by the U.S. government, the South African government, and black South Africans as they explored the possibility of engaging in meaningful negotiations to resolve conflicts and realize individual political gains. Cowell wrote,

Last January [1985], State President P. W. Botha offered to release Mandela if he renounced violence--an offer Mandela could not accept without dividing his own organization and seeming to abandon his followers. The authorities' motives were never spelled out, but they may have included a desire to seem reasonable in the eyes of the Reagan Administration and thus to justify Washington's policy of "constructive engagement." They may, too, have reflected a desire to neutralize Mandela's support.... a further consideration may have been to arrange events so 
that he does not die in prison--an event that would cause massive black anger, whatever the circumstances of death. (1985b, p. F22)

Mandela's role as agency became more apparent in 1989 as reports which featured Mandela began to increase. For example, on July 11, 1989 Thurow reported,

For Mr. Botha, the speculation goes, freeing Mr. Mandela would be an act of statesmanship that could remove a bit of the tarnish of his 11 year presidency....For Mr. de Klerk, Mr. Mandela's release would be a vital first step toward making good on his promises of "a new South Africa." (1989b, p. A16)

In the same article Thabo Mbeki, who directed the ANC's foreign affairs from their exile base in Zambia, was quoted as saying,

The government can't think they can just release Mandela and that will be it. Pretoria will also have to legalize the ANC and also start talking to the ANC. After Mandela's release the ANC will get stronger, more popular. (Thurow, 1989b, p. A16)

A few days later Thurow wrote, "Mandela may be released as the opening gambit" [italics added] to begin negotiations between the South African government and the ANC (1989a, p. A10). Also in July, 1989 Wren wrote,

The government apparently hopes to release Mr. Mandela into some kind of negotiating framework in which he could speak for the country's black majority, rather than let him unconditionally go home to soweto and become, however unwillingly, a focus for reinvigorated black protest....

"Once you release him, how do you utilize him?" asked a prominent Afrikaner...."If you release him and you lose that momentum, you can forget about getting it bound up again." (1989c, p. A3) 
In 1986 Lelyveld reported that there was something special about Mandela. He was not just any ordinary prisoner.

Although Mr. Mandela, 67 years old, has been removed from active politics for half his adult life, his long imprisonment has conferred on him a powerful symbolic status as the pre-eminent black leader of South Africa. (1986b, p. A11)

Lelyveld did not justify his statement with reference to who had conferred this status on Mandela. But, along with other news reports (Battersby, 1987; Lelyveld, 1986b;) the statement characterized Mandela as having the potential to be a significant player in the scene of South Africa.

If the media was to be successful in establishing Mandela as a hero the stories needed to demonstrate material coherence. The narratives needed to be consistent with previous heroic narratives. They needed demonstrate that Mandela possessed heroic qualities such as humaneness, selfsacrifice, and nobility while at the same time remaining true to his principles. Journalists accomplished this by drawing on Mandela's words and writings, by quoting Mandela's associates and prominent public figures, and by expressing their own opinions of Mandela via their writings. Through their writings, journalists demonstrated a positive bias toward Mandela. In 1985 readers learned from a published interview with Mandela's daughter Zenani Diamini that even though Mandela was ill, his first concern was for the black people of South Africa. After a visit with her 
father in prison, Zenani, in reference to Mandela's refusal to accept Botha's conditions for his release, was quoted as saying, "My father looks very well and was very happy to see us," but added that, "he was prepared to die for his ideal of a democratic and free society" ("Mandela advised, 1985, p. A8). The article further states that Zenani believes that her father has "remained unshaken in his beliefs." It goes on, "Throughout his life he has asked for nothing more than the right to decide who should govern on the basis of one person, one vote in a unitary state" (p. A8).

In 1986 readers learned that Mandela, who had been described as a "man of peace" (Lelyveld, 1986b), and his wife, winnie, had been nominated for the Nobel Peace Prize (Cowell, 1986a). Battersby's 1987 article quoted Mandela as saying that he would "bend all his efforts" toward a peaceful solution in South Africa if he were freed ( $p$. A26). Sperry (1981), Weaver (1976), and Lawrence and Timberg (1979) posit there is a "widespread predisposition toward the heroic and melodramatic" (Lawrence \& Timberg, p. 322) in the news. Specifically, Sperry (1981) claims that the dominant narrative form for television news is one the hero plot: "a conflict involving a small cast of characters arises from the introduction of a problem. The problem is to be solved by some representative protagonist whose activity on behalf of the people is designed to ensure that good will prevail" (p. 301). This concept, when applied to news 
reports featuring Mandela, shows that the "hero plot" in these narratives casts Mandela in the role of protagonist and the South African government, and in particular, Botha, in the role of antagonist ("Yes to Mandela's," 1989; "Botha says," 1988; Lewis, 1989). Even though journalists acknowledged Botha's overt actions toward trying to reach an agreement for Mandela's release, nowhere in the articles reviewed was Botha portrayed as having a sincere desire to negotiate with either Mandela or other black South Africans. In fact, articles which made reference to Botha's actions, such as a private meeting with Mandela in July, 1989 (Wren, 1989e) continually speculated on his motives for action. Wren wrote,

President Botha's purpose in holding the historic meeting and not disclosing it is not clear. It seems possible that he wanted to take some credit from F. W. de Klerk, his successor as leader of the ruling National Party, for playing a role in Mr. Mandela's ultimate release. (1989e, p. A1)

Sperry (1981) found in her study of television news that the hero plot is not restricted to individual stories, but gets woven into follow-up reports that stay in the news day after day. In these stories protagonists (heros) are pitted against antagonists (villains) in an ongoing struggle of good against evil. In news reports prior to 1988 we begin to see a glimmer of this scenario, but the hero plot does not begin to take substantial form until 1988. Development of the hero plot in the news reports also serves to further develop Mandela's status as a significant figure in south 
Africa. Specifically, the article headlined "Botha Says He Is Seeking a Way To Permit the Release of Mandela" (1988) cultivated Mandela's significance by revealing excerpts from Botha's speech that deal with Mandela. The article focused on a speech Botha made to the Natal Province Congress. Presidents do not usually refer to individuals in their speeches unless they are of some importance. Additionally, in this article, the hero (Mandela) and the villain (Botha) are more clearly identified. The journalist drew excerpts from Botha's speech which give the impression that Botha, even though he said he wanted to act in a "humane" way was unwilling to make any concessions in the process. The following are representative:

I am not even considering the possibility to discuss black majority government in south Africa....

The A.N.C. must get one message: lay down your arms, come back like decent people, and let's talk about a constitutional future for South Africa....

I am not prepared to create chaos in the name of so-called human rights. I hate no Colored man, I hate no Indian and I hate no black, but I have my own life style and I want to see it continue. ("Botha says," 1988, p. A11)

In reference to Mandela's stay in the hospital for tuberculosis, Botha was quoted as saying,

Personally, I don't think that at his age and condition, it would be wise for him [Mandela] to choose to go back to prison, and I hope he will make it possible for me to act in a humane way so that we can have peace in South Africa. ("Botha says," 1988, p. A11)

From previous articles we know that Mandela had refused to agree to Botha's conditions for release, claiming that if 
he [Mandela] did, he would be compromising his principles (Cowell, 1986b; "Mandela advised, 1985; Gwertzman, 1985a; Lelyveld, 1986b) .

The emphasis placed on Botha's comments and the reference to Mandela, who was recovering in a hospital bed, functions to cast Botha in the role of a stubborn, willful villain, and Mandela as one who was willing to sacrifice his own comfort for humanitarian principles. As late 1989 journalists were still writing about Mandela's refusal to agree to the conditional release, even though Botha made the offer in January, 1989 (Thurow, 1989a). Repeated reference to this issue served to remind readers that Mandela was indeed a unique individual.

In January, 1989 readers began to get a sense of just how significant Mandela was becoming in the social and political scene of South Africa as more articles were published which associated him with South Africa's key political figures, and emphasized that he was a dominant factor in the future of South Africa. The article titled "Is Nelson Mandela Pretoria's Prisoner? Or Is the White Government His Captive?" (Thurow, 1989b) marks a dramatic change in Mandela's role in the media created scene of South Africa. Previous articles gave attention to the possibility of Mandela being released (Battersby, 1987; Botha says," 1988; Lewis, 1989; Wren, 1989C), but in these articles it appeared that the South African government was the dominant 
controlling figure. However, Thurow's article (1989b) suggested that Mandela was the one in control and that the South African government had virtually no choice but to release him. In reference to Botha's July 8th meeting with Mandela, Thurow reported,

Last week, when Mr. Mandela was driven through the prison house gate to the Cape Town home of South African President P. W. Botha, it became clear the government is also a prisoner of Nelson Mandela. For 45 minutes, over tea and cookies, the two old adversaries--Mr. Botha was once quoted as saying Mr. Mandela could "rot" in jail--talked about the need for bringing peace to this racially divided country. Then Mr. Botha sent Mr. Mandela back to prison. But one conclusion is inescapable: the government, desperate to improve its international image and resolve its internal conflict, needs the cooperation and freedom [italics added], of Nelson Mandela. (1989b, p. A16)

These articles illustrate the media's ability to confer celebrity status on individuals. Recall that Boorstin defines a celebrity as a media created "human pseudo-event," a product of the media's ability to create "well-knownness" (See pp. 28-29). Mandela did not become an instant celebrity. His celebrity status evolved gradually as the content of the media reports shifted from a focus on scene, to a focus on Mandela's release. Mandela's celebrity status reached full development when media reports cast him in the role of the key agent who would bring peace to South Africa. At this point Mandela was transformed to the scene itself (See Chapter V). 
NARRATIVES AS GUIDES TO BELIEF AND ACTION

\section{Cultural Myths and Value orientations}

In this section my concern is with the media's value orientations towards the social-political context within which we, as members of the American mainstream interpretive community, are to view and understand Nelson Mandela.

Cultural Myths. Lawrence and Timberg (1979) argue that if we want to adequately understand "the particular forms of heroism that seize our news attention," we must consider the "peculiar mythic traditions of a culture" (Lawrence \& Timberg, 1979, p. 323). Doing so will help us to understand "the selectivities and conventions through which news acquires its heroic story forms (Lawrence and Timberg, 1979, p. 323). The "mere casting of a story in heroic mold" is insufficient to give a story "staying power with the American people" (Lawrence \& Timberg, 1979, p. 323).

In his definition of myth, Robertson describes myths as "the models people refer to when they try to understand their world and its behavior" (1980, p. xv). Myths "provide good 'workable' ways by which the contradiction in a society, the contrasts and conflict which normally arise among people, among ideals, among the confusing realities, are somehow reconciled, smoothed over, or at least made manageable and tolerable" (p. xv). Bennett argues that myth functions as a "code" for reality (1980, p. 168). Our perceptions of reality and our confidence in the accuracy of 
those perceptions are based on a spontaneous adherence to myths and their inherent values. Both myth and media scholars tell us that the use of myth, which guides our perceptions and behavior, is a common occurrence in printed as well as electronic news reporting (Bennett, 1980; Breen \& Corcoran, 1986; Nimmo \& Combs, 1982; Rushing, 1986).

In this section I identify the presence of specific American cultural myths and their underlying value structures found in the reports of Mandela, and analyze them in terms of how they serve as the interpretive framework for public belief and action.

According to Sperry, at the root of the hero plot lies one of our most pervasive myths: "Men muddle through life as best they can, but when tragedy strikes, they require and seek a leader, a single individual of superior worth and superior skill, who will meet the problem and conquer the evil" (1981, p. 300). During the period studied in this chapter, I found only brief reference to the myth that Sperry describes. From the news reports readers learned that Mandela, the most noted leader of the anti-apartheid movement in the early 1960's, was removed from the south African scene. The people's hero, this ostensive champion of the anti-apartheid movement, for all intent and purpose, was no longer able to lead them. But, according to the news reports, Mandela's hero status did not diminish; a new hero was not found to replace him. Even while in prison Mandela 
remained a hero and a legend in his own time (Cowell, 1985b; Dash, 1985).

Even though the myth underlying the hero plot was not fully developed during this period, I found that the news reports, when viewed as fragments of the "master narrative," did lay the groundwork for a more elaborate development of the myth in late 1989 to June, 1990 (See Chapter V). Journalists laid this groundwork, in part, by actually telling readers that Mandela was a remembered hero, that his "fame has grown into a legend, assuming an almost mythical importance..." (Cowell, 1985b, p. F22). This is also accomplished in descriptions of Mandela which referred to him as "the pre-eminent black leader of South Africa" (Lelyveld, 1986b, p. A11), "the leader and soul" of the ANC ("Yes to Mandela's," 1989, p. 26), "South Africa's most celebrated political prisoner" (Wren, 1989d, p. Al), and the "leader" of black nationalists (Cowell, 1986b, p. A3).

In my review of the news reports between 1985 and mid1989 I did find evidence of the presence of two cultural myths, "Presence of Conspiracy" and "Value of Challenge." These are closely related to Sperry's hero plot "root" myth, and to what Larson has identified as the "Coming of a Messiah" myth (1989, p. 227), the latter two of which are discussed in detail in Chapter $V$. We can identify these myths by examining the news reports for the presence of words or phrases that allude to the myths' central themes, 
and belief statements used to express both positive and negative values. The implicit reference to these myths and their inherent values assist the media in the development of a scene in which Mandela can be portrayed as a both an agency of change and later, a hero.

Presence of Conspiracy. According to Larson this myth centers around a belief that "when problems appear great, the only reasonable explanation for them is that a powerful group has conspired to cause them" (1989, p. 227). Part of the power of the Conspiracy myth is the belief that conspirators have the capacity to avoid detection. Conspirators defy detection in that they do not leave a trail of evidence. Hence, a paradox exists. The absence of proof that a conspiracy exists, proves its existence. However, this paradox does not stop individual's from trying to expose the conspirators. News reports suggested that a conspiracy, orchestrated by the South African government and enacted under the name of apartheid, existed in South Africa (Corry, 1986; Cowell, 1985b; Dash, 1985; Gwertzman, 1985a; Lelyveld, 1986b). It was a conspiracy designed to suppress black South Africans by denying them their fundamental rights in order to keep the white minority in power. Lewis made specific reference to this "power."

It hardly follows that the Government is about to abandon the apartheid system. The stake in that is power. And there is no internal pressure equivalent to the Cuban force in southern Angola. The black majority is under control, at least for 
the moment: the townships patrolled by soldiers, many leaders in prison. (1989, p. E25)

The media's portrayal of President Botha made a significant contribution to the development of the conspiracy myth and the idea that the government was conspiring to hold on to white minority power. Botha appeared to be "talking out of both sides of his mouth." On one occasion he was reported to have sent an appeal to black South Africans to "come forward and negotiate with him" (Cowell, 1986a, p. A4), but later he was quoted as saying that, "I am not even considering the possibility to discuss black majority government in South Africa" ("Botha says," 1988, p. A11). Reports of such statements, which appear to contradict each other, perpetuate Botha's role as a villain or antagonist in the narratives and called into question not only the motives underlying his actions, but his credibility as well. Wren (1989c) tells readers that many question Botha's motives. He wrote,

Most political experts see the gesture toward Mr. Mandela as one rooted in the rivalry that developed earlier this year between president Botha and $F$. W. de Klerk, his successor as leader of the ruling National Party and the man most likely to replace him as president in barely two months.

By meeting Mr. Mandela, President Botha has reminded South Africans and the rest of the world that he still runs the country. (1989c, p. A3)

Wren's article also included material which suggested that Botha was not above putting his personal agenda above the needs of his party and country. Wren reported that, 
In March [1989], after Mr. de Klerk had called for a meeting among leaders of all races to discuss the future of South Africa, Mr. Botha went on television to contend that such a meeting had been his idea and depicted himself as a pioneer in dismantling the harsh system of apartheid. (1989c, p. A3)

Several articles suggested that the South African government was unwilling to acknowledge that by sustaining the system of apartheid they were responsible for the deteriorating state of their country's social and economic environment. For example, some articles implied that the South African government had attempted to justify its suppression of various anti-apartheid groups by connecting these groups with communism, which historically has been portrayed as a source of conspiracy. Specifically, Cowell reported, "Inside South Africa it is illegal to do or say anything that might aid the congress [ANC], which south African authorities contend is controlled by its Communist members and by the Soviet Union" (1985b, p. F22). In isolation, this statement does not suggest the presence of a conspiracy, however, on the same page Dash, in his article, wrote that when he questioned Mandela about the ANC's association with Communism, "Mandela dismissed charges that the African National Congress is controlled by the soviet Union or by the South African Communist Party, emphasizing the congress's independence and discipline, and comparing its Communist members to radicals in Britain and other Western democracies (1985, p. F22). In 1989 Lewis implied 
that a conspiracy, designed to suppress anti-apartheid groups and related activities, continued to exist in South Africa when he argued that the "communism" excuse was no longer valid, and therefore, the government needed to change its attitude toward these groups. He wrote,

Over the years Mr. Botha claimed that South Africa faced a "total onslaught" from international Communism. That was a justification for brutal internal repression. But now the Cubans are going. And Soviet officials have been helpful in the negotiations. (1989, p. E25)

Value of Challenge. This myth is also closely related to Sperry's heroic "root" myth and Larson's "Coming of a Messiah" myth. According to Larson, this myth "suggests there is a kind of wisdom gained only through great challenge and testing. There is a rite of passage or initiation that gives one power, character, and knowledge" (1989, p. 227). Stories which are illustrative of this myth suggest to the reader that: 1) "There is something good about suffering or that nothing good was ever accomplished without pain;" 2) "suffering begets maturity, humility, and wisdom--you learn and grow as you meet challenges and surmount them" and; 3) "all great leaders have become great because they were tested and found to equal the challenge" (Larson, 1989, p. 229).

News reports told us that while in prison Mandela's principles, aspirations, resoluteness, and perseverance were severely tested, and yet he prevailed. Mandela never strayed from his mission to put an end to apartheid. Cowell writes 
that at Mandela's 1964 trial, "Mandela spoke of 'the ideal of a democratic and free society in which all persons live together in harmony and with equal opportunities.' Since then, Mandela's incarceration has honed the message. No stigma of compromise or doubt is attached to his name" (1985b, p. F22).

Additionally, news reports suggested that Mandela had faced the challenge of being imprisoned and it appeared that he was winning. The South African government was beginning to relax their position of refusing to negotiate with Mandela for his release (Cowell, 1986a; Lelyveld, 1986b;).

Value Orientations. Larson tells us that values and beliefs are "trained into us" through the myths and tales we hear and "our observations of how those around us behave" (1989, p. 220). The U.S. print media contributes to this training when journalists use narratives, that contain reference to cultural myths. These myths, even though they may not be explicit, can help the reader identify with the characters and their value orientations and behaviors.

\section{Sillars states,}

Rarely do we see a text that is dominated by two or three salient values and it is virtually impossible to find one built upon only one value. Most often a critic will identify a system of values. The term system implies that values are linked to one another, influence each other's meanings, and provide the basis for a generalization characterizing the cognitive system. (1991, pp. 132-133) 
Reference to several American values and/or value systems were found in the news reports as journalists incorporated cultural myths into their writing. Recall that values can be inferred from belief statements (see p. 49), and that negative value terms or statements represent the opposite of the preferred (Sillars, 1991).

Although value statements express a judgment about what is a desired end state or action, value statements are not always explicit in messages. Gans tells us that all statements can be interpreted for values. In reference to the media Gans says that,

The values in the news are rarely explicit and must be found between the lines--in what actors and activities are reported or ignored, and in how they are described. If a news story deals with activities which are generally considered undesirable and whose descriptions contain negative connotations, then the story implicitly expresses a value about what is desirable. In the process, the news also assumes a consensus about values that may not exist, for it reminds the audience of values that are being violated and assumes that the audience shares these values. (1979a, pp. 39-40)

To illustrate Gans' claim I use an excerpt from an editorial printed in The New York Times (January 27, 1989). The underlining of words is mine.

President F.W. de Klerk has led his Government to the verge of talks on ending apartheid in South Africa. But now he balks at the very moment when the climate for negotiations with the black majority has never been better--and when it could easily get far worse...

The de Klerk Cabinet seems to have ignored the peaceful thrust of the congress's [ANC] plan. Instead, it has chosen to focus on A.N.C. refusal to renounce violence, a step the Government demands as a precondition for talks. This cynical 
reasoning suggests what Mr. Mandela calls the real problem: "The Government is not yet ready for negotiation and for the sharing of political power with blacks."

Mr. de Klerk seems not to appreciate how reasonable Mr. Mandela and the other A.N.C. senior leaders are, and how seriously they are being pressed by younger, more militant blacks who have no use for negotiations with whites. ("Yes to Mandela's," 1989, p. 26)

The only explicit value term found in the above quote is the use of the word "peaceful." Use of the term "ignored" in conjunction with "peaceful" attributes negative connotations to the Cabinet's position. The suggestion is that the Cabinet did not consider peace of primary importance. The word "cynical" used in conjunction with "reasoning" implies a negative type of reasoning. The implication for the reader is that the Cabinet did not trust the ANC and was not very optimistic about the possibility of peaceful negotiations. Additionally, the above words and the phrase "seems not to appreciate how reasonable Mr. Mandela and the A.N.C. senior leaders are" casts de Klerk and his Cabinet in antagonistic roles. The writer implied that when the issue of peaceful negotiation is approached with doubt, cynicism, distrust, and faulty reasoning the chances of success are in doubt. This article suggests that reasonableness, decisive leadership, trust, and cooperative action are desirable and necessary conditions. In addition, the above excerpt gives the impression that a conspiracy to maintain white minority power continued to exist. 
After an extensive review of news articles which focus on Mandela, I have been able to identify three dominant value systems outlined by Sillars (1991). These are: the Enlightenment, the Progressive, and the Collectivist value systems. The following section focuses on the Enlightenment value system since it is dominant in the period covered in this chapter. The Progressive and Collectivist systems will discussed in detail in Chapter $\mathrm{V}$.

As I discuss each of these systems keep in mind that in a given article we may find combinations of systems and the hierarchy of these value systems may vary from story to story. I make reference to other value systems only if they seem dominant in a particular article.

Enlightenment Value System. As discussed earlier, the underlying theme of equal rights found in virtually all of the narratives reviewed points to the presence of a dominate value system that can be identified in individual narratives which make-up the master narrative. This system is the Enlightenment value system. The system is based on the belief that, "We live in an ordered world in which all activity is governed by laws similar to the laws of physics" (Sillars, 1991). By discovering these laws, through reasoning, one can improve the quality of his/her life. According to Sillars, "Reason must be free. Thus, government is an agreement among individuals to assist the society to protect rights. The government is a democracy. Certain 
rights are unalienable, and they may not be abridged" (p. 139).

The situation in South Africa with its governmentsponsored system of apartheid offends the Americans sensibility based as it is in Enlightenment values. Apartheid is in direct opposition to several primary American values. It is not a democracy and hence U.S. journalistic accounts of South Africa and Mandela continually alluded to the need for a basic restructuring of the South African government.

Terms often used to describe the Enlightenment value system include: democracy, freedom, individualism, liberty, natural right, progress, rationality and reason (Sillars, 1991). As illustrated below several articles used these terms and corresponding negative value terms when describing people and events in South Africa.

Even though Cowell in his article titled "Pretoria Promises City Blacks 'a Say'" (1985a) did not mention Mandela, it does illustrate the media's tendency to portray then-President Botha and his government in a negative way. The article implied that Botha and the government did not subscribe to fundamental American values.

In his lead paragraph Cowell wrote that Botha had promised "blacks living outside the country's tribal homelands a greater political voice" but had no plans to "dilute the white Afrikaner power that has prevailed since 
1948 (1985a, p A2). In this article there was no indication as to how Botha defined "greater political voice." Botha was quoted as saying, "It remains the Government's point of departure that because of the diversity of South African society, it is neither desirable nor practicable to accommodate all communities in the same way (Cowell, 1985a, p. A2). In other words, there may be change but it would still be restrictive.

Botha's comments and Cowell's writing suggest that South African government policies were in direct opposition to the Enlightenment value system which is based, in part, on a belief that certain rights are unalienable. Blacks did not have democratic freedoms. They could not vote and were not free to live, work, or travel where they wanted. When reading the article one gets the impression that Botha and his administration did not value or define democracy, natural laws, and natural right to the same degree or in the same way Americans do. The South African government had failed to "protect the rights" of all the people (Sillars, 1991, p. 139).

Another article by Rule (1985) elaborated on the issue of granting citizenship rights to blacks and further demonstrates what appeared to be a fundamental difference in the value orientations of Americans and the South African government. Evidently, when tribal homelands were granted a degree of independence, with the power to govern themselves 
on a local level, they were "stripped" of their citizenship in South Africa. The article was a bit misleading for it implied that previous to the establishment of tribal homelands blacks were considered citizens of South Africa. By definition a citizen is, "a member of a state or nation who owes allegiance to it by birth or naturalization and is entitled to full civil rights" (Guralnik, 1983, p. 113). Since the periods of European conquest and colonization, Blacks in South Africa have never enjoyed the freedoms associated with full civil rights. They have, and continue to be, discriminated against politically, economically, and socially.

However, in this article, as with the previous one, there is implicit reference to the Enlightenment value system. Rule wrote that whatever Botha's plan was,

Political commentators said that it was certain that the Government would not offer blacks the most fundamental right of citizenship, the right to vote in the central political system....the plan would leave untouched the basic principle of apartheid that in effect maintains that the 6 million whites should not be dominated by the 23 million blacks. (1985, pp. A1, 8)

The value Americans place on freedom, individualism, and democracy, and the lack thereof in the South African government, is further demonstrated in two 1988 articles. The lead in Battersby's (1988) article informed readers that 17 anti-apartheid organizations, including the largest, the United Democratic Front and the major labor federation, had been banned from all political action. Although Battersby 
did not offer a personal opinion his use of the words "banned" and "barred" in conjunction with "political action" suggest the presence of negative values such as the suppression of freedom to assemble and freedom of speech. In addition, readers were told that "Western officials" (who we can assume subscribe to the Enlightenment value system) reacted to the banning "with shock and sharp dismay" (1988, p. Al). Peace loving individuals such as Nobel Peace Prize recipient Archbishop Tutu appeared to respond similarly. Tutu is quoted as saying,

Peaceful paths to change are being closed off one by one, and those wanting real change are being encouraged by the Government's actions to turn to violence.

White South African's must realize that they are at the crossroads. If they don't stop this Government soon, and there's not much hope that they will, we are heading for war. (Battersby, 1988, p. A1)

The article, with quotes from Tutu, implied that freedom and democracy are not only desired states, but necessary if peaceful co-existence was to occur.

American readers learned from Gerard's article that not only were the basic rights of blacks restricted and controlled by the South African government, but the freedoms normally enjoyed by the international press had been severely restricted. Readers were told that restrictions on the press, imposed in November, 1985, severely limited the type and degree of information reported. These restrictions required "police supervision of journalists in areas of 
unrest covered by emergency decree... and ban picture and sound recording in those areas (1988, p. C18). Here again, reference was made to the Enlightenment value system where the situation was described in negative value terms.

It becomes apparent in an article titled, "Botha says He Is Seeking a Way To Permit the Release of Mandela" (1988) that Botha was unwilling to put basic human rights above his own personal freedoms, values, and beliefs. Here he was quoted as saying, "I hate no Colored man, I hate no Indian and I hate no black, but I have my own life style and I want to see it continue" (p. A11). In essence he was saying that his rights take priority over the rights of others.

In each of the above articles the implicit suggestion was made that a government which does not embrace the Enlightenment value system is likely to witness violent opposition by those whose rights are violated. In fact, reference to this value system was used as a justification for protest: When people's basic rights are abused and the government won't step in and protect those rights people are forced to act on their own. Note that what was occurring is the creation of an image of the South African government as a powerful, repressive entity that continually violated the values we (Americans) consider of primary importance. As we will see later, this image did not change significantly until January, 1990 when news stories of Mandela focused on cooperative, progressive change. 
of particular importance in the development of Mandela's hero persona, for the American public, was the need to provide evidence that Mandela subscribed to many primary American values. The media revealed Mandela's value orientations through the selective reporting of his actions and by quoting him directly. In contrast to the above image of the South African government presented in the news reports, Mandela was shown to champion the Enlightenment value system. As early as 1985 readers were told that Mandela supported, "the ideal of a democratic and free society in which all persons live together in harmony and with equal opportunities" (Cowell, 1985b, p. F22), and that he would "bend all his efforts toward a peaceful solution in South Africa if he were freed" (Battersby, 1987, p. A26). His dedication to the achievement of equal rights for black South Africans was reinforced when his daughter was quoted as saying that Mandela was, "prepared to die for his ideal of a democratic and free society" ("Mandela advised," 1985, p. A8). However, according to the news reports, Mandela was not immune to the needs and concerns of the white south African minority. Readers learned that,

In an essay written last year [1988] and published this week, he [Mandela] sketched his principles for talks. One is the goal of black majority rule in a unitary state. The other is "structural guarantees that majority rule will not mean domination of the white minority by blacks." ("Yes to Mandela's," 1989, p. 26) 
In April, 1989 Battersby told the American public that from his jail cell Mandela "has called for black unity in south Africa and an end to three years of fighting between factions of the Zulu tribe" (p. A3). Mandela was quoted as writing,

I consider it a serious indictment against all of us that we are still unable to combine forces to stop the slaughter of so many innocent lives....

At no other time in our history has it become so crucial for our people to speak with one voice and to pool their efforts. (Battersby, 1989, p. A3)

Mandela's statement speaks not only to the Enlightenment value system, which embraces the values of freedom and peace, but also to the collectivist value system. This system is based on a belief that collective action can benefit society (Sillars, 1991). In the above article Mandela was calling for cooperative action, but he stressed that this action must be peaceful. Fighting and killing, particularly among blacks, was seen as an obstacle to freedom and peace. In Chapter V I will elaborate on the Collectivist value system.

\section{SUMMARY}

During the period covered in this chapter, journalists used Mandela's incarceration to elevate his status rather than diminish it. Coverage of his incarceration and rumors of his possible release provided the substance for the creation of a series of pseudo-events which depicted south 
Africa as a country where significant changes were about to occur. Pseudo-events are, in essence, scenarios of what we should expect to see happen in the future (see pp. 26-27). When the presentation of pseudo-events incorporate terms like or similar to the terms used to talk about cultural myths the possibility that the reader will get caught up in the story and follow it to its conclusion increases. Why? Because even though the average reader may not be readily able to identify a specific myth in a media narrative, the presence of the myth, with its underlying values, gives the narrative a "familiar ring." The cultural myths provide an interpretative framework for readers. The proliferation of pseudo-events provide the foundation for future stories in which readers are invited to share in not only the celebration of Mandela's release, but in the hopes and dreams of millions of black South Africans. Sperry claims that a function of narrative form is to invite an audience to respond emotionally.

A news narrative, as does any narrative, engages the imaginative--hence inevitable, emotional-response of the viewer. Narrative asks what are they [the characters] like, why do they act, how does it feel, and invites the attendant emotional, imaginative realization of those questions. (1981, p. 307)

Recall that media critics such as Parenti (1993), Graber (1984), Bagdikian (1987), and Gitlin (1980), argue that the general public looks to the media for definitions of significant issues or events. During the period studied 
in this chapter the media continually told readers that the situation in South Africa and Mandela were significant issues. The practice of retelling essentially the same story over an extended period of time (1985 to mid-1989), signals the beginning of the development of what Bormann (1985) refers to as "stock scenarios." These scenarios, "a unified putting-together of the various scripts," provide the substance for future stories (Bormann, 1985, p. 133). They provide readers with a "unified script" for understanding that which they have not directly experienced.

\section{PREVIEW OF CHAPTER V}

Chapter $\mathrm{V}$ follows the same format as Chapter IV focusing on the period from late 1989 to June, 1990. 


\title{
CHAPTER V
}

\section{A SYMBOL OF FREEDOM--}

THE PUBLIC PERSONA OF NELSON MANDELA

MID-1989 TO JUNE, 1990

\begin{abstract}
"He is the symbol of our people. His imprisonment represents our oppression. His self-sacrifice is what we would all like to be in resisting that oppression. His release has come to symbolize the liberation we are longing for."
\end{abstract}

...Desmond Tutu, 1990

\section{MASTER NARRATIVE}

From mid-1989 to June, 1990 media reports of Mandela placed him in a scene wherein negotiation and progressive change were the vehicles by which South Africa could move toward establishing a democratic society. In September, 1989 F. W. de Klerk was elected president of South Africa. During his inaugural address de Klerk promised "a totally changed South Africa...free of domination or oppression" (Gimlin, 1990, p. 545). A few days later, even though a state of emergency was in place, de Klerk announced that peaceful demonstrations would be allowed. On October 16, 1989 de Klerk released eight of South Africa's most prominent black political prisoners (Wren, 1989b). And finally, on February 
2nd the government lifted the ban on the ANC and the south African Communist Party "after 30 years of relentlessly vilifying the organizations" (Thurow, 1990a, p. Al). As reported by the media, the above events demonstrated that President De Klerk was far more willing to recognize and work with various political groups than was past-president Botha. The government appeared to be actively seeking to create a climate that was conducive to peaceful interaction with its political opponents. But where was Nelson Mandela? He was still in prison. By July, 1989 the question was no longer, will Mandela be released, but when will the release occur?

Unlike the previous period (See Chapter IV) in which development of Mandela's persona and his role as a co-agent spanned a three and a half year period, the development of Mandela into a full-fledged celebrity and hero, who was depicted as the pivotal force in the changing south African scene, occurred in just a few short months. From August, 1989 to the first part of February, 1990 the media cast Mandela in the role of South Africa's most prominent political figure. Even President de Klerk was often given second billing to Mandela (Burns, 1990c; Rotberg, 1989; Thurow, 1990g; Washington Wire, 1989).

On February 11, 1990 Mandela walked out of prison and was instantly transformed, by the media, from the central actor in the South African scene, to the scene itself as he 
began to dominate more and more of the media's coverage of South Africa. In the news reports Mandela became the personification of South Africa's political and social Iandscape.

Between August, 1989 and February 10, 1989 (the day before Mandela's release) I found 15 articles featuring Mandela, and from February 11 to June, 20 (the day of his arrival in the U.S.) I found 25 articles. All of these articles were taken from the "mainstream U.S. print media" identified in Chapter I (see pp. 13-14), and were circulated to other U. S. newspapers via the Associated Press news wire.

In this chapter I describe the evolution of Mandela's public persona from mid 1989 (immediately prior to his release) to June, 1989 (immediately prior to his visit to the United States). I will also evaluate the reports in terms of how they function to establish Mandela as a hero, and how these reports serve as guides to belief and action for the reader.

\section{EMERGENCE OF THE MASTER NARRATIVE}

Consistent with the period discussed in Chapter IV, the central themes of change in the form of political cooperation and compromise, improved political and economic relations, and equal rights, dominate the narratives of Mandela from mid-1989 to June, 1990. But unlike the previous 
period, where the actions of various co-agents/actors produces a tension between the scene and those actions, the master narrative from mid-1989 to June, 1990 casts Mandela in the role of central actor who is transformed from actor to scene upon his release from prison. As scene, Mandela contains or frames all other elements (actors, purpose, agency) of the dramatic messages. Mandela is elevated to a position that portrays him as the "savior" of millions of black South Africans. The message is clear: Mandela is the nation's last chance for peace; it is now up to him to lead his country into a future devoid of racial conflict. He personifies not only millions of black South Africans, but the entire political/social scene of South Africa.

The violation of human rights for black South Africans is manifested in the political and social repression of blacks that has been going on for over 300 years. U.S. newspapers have reported, with varying degrees of intensity, the social climate in South Africa for years. However, the articles which focus on Mandela during this period make few direct references to the racial turmoil in South Africa. They allude to the violation of human rights in the manner in which Mandela's role is described and the labels used to describe supporting actors and the scene in South Africa. For example, Thurow's article (1990f) reminds the reader that "state-enforced" racial segregation had existed in South Africa for over 40 years, that blacks had never had 
voting rights, and racist attitudes among many whites were both powerful and enduring (pp. A1, 4).

From mid 1989 to June, 1990 the media continued the practice of "serial" reporting (Bennett, 1983). Mandela and his actions were covered in-depth over an extended period of time. This practice helped to establish Mandela as a significant subject for the reading audience. As Tuchman states, "Those topics given the most coverage by the news media are likely to be the topics audiences identify as the most pressing issues of the day" (1978, p. 2). In this case it is Mandela.

\section{NELSON MANDELA'S PUBLIC PERSONA}

By mid 1989 Mandela's public persona had evolved to include the attributes of political power and influence. His meetings with South African officials were emphasized and speculation as to his future role in the ANC and south African politics was debated ("Black leaders," 1989; Rotberg, 1989; Washington Wire, 1989; Wren, 1989a). Wren wrote,

By all accounts so far, President Botha was not negotiating with Mr. Mandela. But the President was seen to be acknowledging what the leadership of the anti-apartheid struggle has long argued-that Mr. Mandela, and by implication the African National Congress, is indispensable in any successful discussion of South Africa's future. (1989c, p. A3)

In July, 1989 Thurow (1989b) suggested that Mandela rather than Botha was in control of the negotiations for his 
release (See p. 99). Rotberg continued to develop this theme in August with an article titled, "South Africa's Tide Shifts" (1989, P. A23). These two articles signaled the beginning of a movement, by the media, to establish Mandela as not just a co-agent/actor in their narratives, but as the key agent or central actor. Rotberg, in his analysis of the South African scene, wrote, "Nelson Mandela holds the keys. $\mathrm{He}$ is South Africa's true jailer, and the country's white leaders his prisoners" (1989, p. A23). As with previous articles, speculation of the motives which drive governmental decisions were continually questioned. This action functioned to perpetuate the impression that the South African government was the antagonist and Mandela was the protagonist. Rotberg's article is particularly interesting because he suggested that the government was actively working to promote Mandela as a hero for its own purposes:

The gradual shift of Mr. Mandela, 71, from antihero to hero, is intended by the whiteminority Government to confer a new legitimacy on him and, according to a recent speech by Mr. de Klerk, also on the African National Congress, Mr. Mandela's exiled and banned guerrilla movement... The fact that white South Africa courts Mr. Mandela, may even be negotiating at a low level with the A.N.C. and hardly tries to prevent large delegations from making the trek to Lusaka, Zambia, to meet and be impressed by the A.N.C. leaders, adds excitement and new hope to those who seek peace in South Africa. (1989, p. A23)

The degree of Mandela's influence was further developed by Burns in his article titled, "Mandela, 'Faceless Man With 
a Fax' Negotiates His and His Nation's Future" (1990C, p. A3). Here South Africa's "best-known political satirist," Pieter-Dirk Uys was quoted as saying, "Who would have thought that a faceless man with a fax machine could run the country from a prison?" ( $p$. A3). Burns described Mandela as "the symbolic-leader of millions of blacks" who appeared to be outlining not only the conditions of his own release but "what could be the future of South Africa" (p. A3).

There is a potential problem in the development of Mandela's hero persona, which had to be resolved if the media was to be successful in establishing Mandela as a "man of peace," and that was his relationship with the ANC. Prior to this time reports on ANC activities focused on its involvement in violent resistance to apartheid and its communist ties. Mandela had been referred to as the ANC's "most prominent leader," and its "soul" (Lelyveld, 1986a, p. A3; "Yes to Mandela's," 1989, p. 26).

If the American public had any reservations as to Mandela's position, prior to his release, regarding violent resistance they were soon appeased by the U.S. media.

Unlike previous articles which associate Mandela with the "Spear of the Nation" (ANC's military arm previously led by Mandela) media narratives immediately prior (January/February, 1990) to his release sought to disassociate Mandela with this arm of the ANC. For example Burns told readers that based on Mandela's discussions with 
the South African government it appeared that Mandela was no longer a strong supporter of violent anti-apartheid activities but instead sought peaceful resistance and negotiations as a way to achieve equal rights.

Still what Mr. Mandela has begun [discussions with the South African government] implies a shift away from the sporadic guerrilla campaign he launched with the founding of the congress's military arm, spear of the Nation, in 1961, and back toward an emphasis on attaining legal status. (Burns, 1990e, p. E3)

Here the journalist sought to distance Mandela from the more radical members of the ANC. He also illustrated a consistency in Mandela's philosophy and value orientations that spans a 27 year period when he included a quote Mandela made prior to his imprisonment.

I have fought against white domination, and I have fought against black domination. I have cherished the idea of a free and democratic society in which all persons live together in harmony and with equal opportunities. It is an idea which I hope to live for and achieve. But if needs be, it is an idea for which I am prepared to die. (Burns, 1990 e, p. E3)

The inclusion of the quote implies that Mandela was not then and never had been an advocate of violence. The appeal of this type of article for the reader is the portrayal of Mandela as a man who valued peaceful discussion and negotiation. Mandela was depicted as a man who could be admired and respected.

Smith's (1990) article addressed two key issues, relating to the above, which influenced the development of Mandela's persona: 1) Mandela's and the ANC's ties to 
communism and, 2) individual rights vs. group rights. Smith pointed out that Mandela, in his July, 1989 essay to Botha, stated that he was not and never had been a communist, and that the ANC is committed to socialism. The role of communism in the anti-apartheid campaign was described as primarily a supportive one. The ANC considered the African Communist Party an "ally" who had given them moral and financial support when democratic countries had turned their backs on them. Smith (1990) stated that the ANC would hold firm in its demand that individual rights must take priority over group rights. Group rights, according to smith, was the foundation of apartheid policy. The tone of this article was one that endorsed and supported Mandela's association with communism and a persuasive argument was made to justify this position (Smith, 1990).

During the period from late 1989 to June, 1989 we see the full development of Mandela's legendary status in the news reports. Reports published just prior to Mandela's release continually reinforced the image of Mandela as a "legend" and a "hero". Again and again he was referred to as the "world's most famous political prisoner" (Burns, 1990d, p. A6; Burns, 1990e, p. E3; Smith, 1990, M2; Thurow, 1990C, p. A9). The legend of Mandela, as a folk hero of black south Africans, was perpetuated as journalists described him in ways that bestowed on him almost superhuman qualities. For example, Burns (1990c, p. A3) described Mandela as, "the 
symbolic leader of millions of blacks." Mandela was not a leader in the physical sense, but in the cognitive and affective sense: Here was a person who, in spite of being silenced behind bars for over twenty-seven years, represented freedom and justice for black South Africans.

An interesting twist on this theme were headlines which read, "Freed Prisoners Call on Pretoria To Let Mandela Go" (Wren, 1989b). Note the biblical connotations. In this case the situation is inverted, the people are free (in a manner of speaking) and it is the leader who is in bondage. This theme was highlighted again on the day after Mandela's release in a news story titled, "Mandela Termed a Moses Among Blacks" (Kraft, 1990b). In Kraft's article Mandela was described as, "the primary unifying force in the deeply divided politics of South Africa's 27 million blacks" (1990b, p. A14). Readers also learned from this article that the name Mandela is,
...a rallying cry for black youths born years after he was sent to prison. Songs are sung and poems are written about him in the urban black townships and children are named for him in even the most remote villages. (p. A14)

These biblical references accord a secured moral dimension to Mandela's persona.

The legend of Mandela was also perpetuated in Thurow's article when he wrote about Mandela's neighbors.

Selina Mkhabela is waiting anxiously for her neighbor [Mandela] to return.... She has never seen the man [italics added] who owns the bungalow across Vilakazi street. On Saturday night, hours 
after his intended release was announced, she is sitting on her porch, watching the Mandela yard fill with revelers, and, of course, expectations. "His release is like a victory to us. Even if he is old he can still fight with his brains. He'll know how to end our problems." Scelo, her 13 year old son, is anxious to cross the street and shake his neighbor's hand. "Our teachers say he started to get people to fight for what they believe in. Now he's coming back to finish what he started." (Thurow, 1990e, p. A7)

The inclusion of reports, such as the one above, assists the reader in developing an understanding of just how important Mandela's freedom was to black South Africans. Readers had the opportunity to relate more closely with black South Africans, they could begin to feel what they were feeling.

In Fuchsberg's (1990) article we also learned that what he calls "Mandela-mania" had been building for years (p. A7). Fuchsberg wrote,

While he was behind bars, Florence, Rome and nine other Italian cities conferred honorary citizenship upon Mr. Mandela, as did Athens and Glasgow, Scotland. He has received prizes from Cuba's Fidel Castro, Nicaragua's Daniel Ortega, and governments in India, East Germany, Austria, and Venezuela. The Soviet Union put his image on a stamp. In Britain, nuclear physicists once even named a subatomic particle after him.

With hundreds of accumulated accolades, $\mathrm{Mr}$. Mandela may well be the most honored-in-absentia man alive. ( $p . A 7$ )

Note that this was the first time since the early $1980^{\prime} \mathrm{s}$ that mention of these honors were included in U.S. media stories of Mandela. The reports provide us with another example of selective news reporting. 
Excerpts from an essay written by Mandela in July, 1989 and sent to President Botha prior to their July meeting reached the pages of U.S. newspapers in January, 1990 ("Excerpts from," 1990). It was here that the reader received a profile of Mandela's character through own his writing. Recall that during the previous period studied, reports including direct quotes from, and the writings of Mandela were limited.

These excerpts, drawn from his essay, dealt with Mandela's relationship with the ANC, his role as a communist, and his hope for peaceful negotiations between anti-apartheid groups and the South African government. The media highlighted Mandela's desire for peaceful negotiation in lieu of violent resistance. This was consistent with articles dating back as far as 1985 (Dash, 1985; Lelyveld, 1986a; Lelyveld, 1986b; Battersby, 1987). For example, Mandela wrote,

The deepening political crisis in our country has been a matter of grave concern to me for quite some time and I now consider it necessary in the national interest for the African National Congress and the Government to meet urgently to negotiate an effective political settlement. ("Excerpts from," 1990, p. A6)

The publication of these excerpts is an excellent example of what media critics refer to as "the constructed reality of the media" (Gans, 1979a; Gitlin, 1980; Schudson, 1982; Tuchman, 1978). The reader learned about Mandela's character from bits and pieces of selected information; the 
complete essay was not available for public evaluation.

Therefore, the reader had to assume that what was published was an accurate representation of the general content of the essay.

Immediately prior to Mandela's release (January, 1990) journalists created dramatic expectation, an elevation of tension. The containment of actor within an inappropriate scene must give way, and in so doing, the actor was transformed into scene.

The tone of U.S. news stories became almost "electric" as journalists told readers of the excitement building on the streets of South Africa in anticipation of Mandela's release. U.S. newspapers sought to capture the attention of millions of readers as journalists emphasized the significance of his forthcoming release on the daily lives of South Africans. Burns wrote,

With quickening intensity, South Africans everywhere from the plush northern suburbs of Johannesburg to the dusty back alleys of Soweto have been snapping up the final editions of newspapers at street-corner stands, silencing gatherings to listen to the television news, and collectively sitting on the edge of their seats for news of what everybody seems to regard as one of the most momentous events in South African history: the release of $\mathrm{Mr}$. Mandela who has been continuously in South African jails since August 5, 1962. (1990c, p. A3)

The language used in this article was replete with imagery. The American reader could visualize the situation in South Africa and liken it to previous images of Americans gathered around their television sets and radios waiting to 
hear news of an attempt on President Reagan's Iife or the assassination of President Kennedy.

Anticipation builds. Something exciting and significant was about to happen! Thurow told the American public,

As foreign journalists, particularly television crews, pile into the country to chronicle $\mathrm{Mr}$. Mandela's release--the government [South Africa] says it is a matter of when, not if--south Africans are awash in deja vu. (1990g, p. A12)

Readers were also told that the impact of Mandela's forthcoming release on the international business community had caught the attention of business people around the world. Thurow reported, "Corporate board rooms are nearly as excited as the nation's black townships over the impending release of the world's most famous political prisoner" (1990g, p. A12).

The stage was set for Mandela's release. And on February 11, 1990 as Nelson Mandela walked out of Victor Verster Prison he was greeted by a crowd of 5,000 blacks and whites who chanted his name (Burns, 1990a). A few hours later he spoke before a cheering crowd of 50,000 from the steps of Cape Town's City Hall while millions of people around the world watched the celebration on television (Burns, 1990a). Mandela's release became the people's release. In this sense Mandela was the scene. The moment he walked out of prison he became the people's new South Africa. 
On February 11, 1990 and for the remainder of the month the American public was inundated with news reports of Mandela's release. The mere fact that on February 12 The Los Angeles Times, and The New York Times devoted three frontpage columns with major headlines to Mandela's release, told the American public that an event of major significance had occurred (Kraft, 1990a; Burns, 1990a). The front-page story in The New York Times was so extensive that it continued on page 16 and took up the entire page. And page 18 of the same paper was devoted entirely to Mandela ("South Africa's new," 1990). In the news stories reviewed, Mandela was transformed from actor to scene. Once this had occurred the ratio (tension among elements) shifted. Mandela, as scene, was defined through purpose. The central purpose found in the narratives was the achievement of a free democratic society. As Mandela moved from actor to scene the central theme in the narratives changed from speculation on his release to whether or not Mandela would be successful in bringing peace to his country.

During the days immediately following Mandela's release readers began to get a sense of the degree of accuracy in the media's predictions as to Mandela's role in South African politics. In other words, how accurate were previously reported stories that were framed as pseudoevents (See pp. 27-28) ? Were predictions made during the previous period consistent with the current situation? 
Recall that pseudo-events are usually intended to be a selffulfilling prophecy (Boorstin, 1961). Pseudo-events are planted in the news to draw attention to individuals or events. They report not only what has happened and is happening, but more importantly, they speculate on what is expected to happen. Forecasts for the future function as "leaders" for future stories. They pre-dispose audiences to expect certain events to occur at a later date. When it is shown that a consistency exists between previous stories and current stories the pseudo-events assist in establishing a thread of consistency among the stories.

According to the news reports, the world had waited with eager anticipation for Mandela's release and reports documented the initial excitement and celebration accompanying Mandela's release on February 11. A picture printed in the February 11 issue of The New York Times under the headline "S. Africa to Free Black Leader Mandela Today" showed Archbishop Desmond Tutu dancing in the streets of Soweto, with other black residents, celebrating Mandela's release. Kraft reported that when Tutu heard the news of Mandela's imminent release he got out of his car and "leaped into the air, shouting 'Hooray!'" (1990a, p. A14). Tutu stated,

F.W. [de Klerk] you have done well. Today is not a day to be churlish. It is a time to say, 'Yeah!' It is a time to celebrate. Nelson is going to be the focus of all our aspirations. He will unite us. (1990a, p. A14) 
Various articles and accompanying photos told of jubilant celebrations in the black townships and major cities of South Africa (Burns, 1990a; Burns, 1990c; Kraft \& Cart, 1990; Thurow, 1990e; "Transcript of Mandela's," 1990; and Wren, 1990a). Burns (1990c) wrote that one of the most surprising developments was the obvious excitement of many South African whites in anticipation of Mandela's release. According to Burns, there were large numbers of whites present who cheered Mandela outside Victor Verster prison, along the route into Cape Town, and at the rally outside City Hall (1990a).

In response to Mandela's release Clarence Keyter, a white South African television commentator stated,

There is a warm wind blowing in Paarl. The sun is not just for the growing of grapes but the sun is shinning on South Africa. This is a historic moment in the history of South Africa. ("Broadcast in South Africa, 1990, p. 15)

The news reports also provided readers with a glimpse of U.S. and world-wide response to Mandela's release in several articles, including those which addressed president Bush's reactions ("Around the World," 1990; Farnsworth, 1990; Lyall, 1990; Thurow, 1990e; Thurow, 1990f). For example, one article stated that Mandela's release "prompted an outpouring of praise and excitement around the world yesterday from Government leaders, relatives of $\mathrm{Mr}$. Mandela 
and former political prisoners" ("Around the World," 1990,

p. A16). This article stated that:

In Warsaw, the Solidarity leader, Lech Walesa...praised Mr. Mandela as a man who had devoted his life to equality of all people.

In Britain, where church belis rang throughout the country to celebrate the release, Prime Minister Margaret Thatcher said she would ask the 12-nation European Community to lift some sanctions as a reward for Mr. Mandela's release.

In Amherst, Mass., one of Mr. Mandela's daughters, Makaziwe Mandela-Ameeah... watched on television as her father left the prison. She called the scene 'an experience that will live for me forever.' Her living room erupted in yells, tears, and clenched fists when her father was freed. ("Around the World," 1990, p. A16)

Lyall told readers that several hundred people gathered at the House of the Lord Pentecostal Church in Brooklyn on February 11 to celebrate Mandela's release. One member, Doris Pinn was quoted as saying,

I feel absolutely exhilarated, His [sic] incarceration was symbolic of the incarceration of blacks across the world--politically, socially and economically--and his release is symbolic of the breaking of the chains. (Lyall, 1990, p. A17)

In the same article New York Mayor David Dinkins told journalists that he was "elated by the news of Mr. Mandela's release" (1990, p. A17).

Mandela's release marked a critical point in the evolution of his persona in the U.S. print media because he could now be quoted directly. One of the most significant reports found at this time was the transcript of Mandela's address at cape Town city hall on February 11 ("Transcript of Mandela's," 1990, p. A15). This transcript bestowed 
credibility on previous articles in that it demonstrated a consistency in what was reported about Mandela and his actual statements. Whereas in previous years Mandela was introduced to the American public via journalistic reports, now Mandela could speak directly to the American people. The media portrayed Mandela as a man who was a staunch supporter of peace, democracy and equal rights. This image was confirmed when in his opening remarks Mandela said, "My friends, comrades, and fellow South Africans, I greet you all in the name of peace, democracy and freedom for all" (p. A15). Mandela's dedication to his country and its people, as suggested in the Dash (1985) and Cowell (1985b) articles were reinforced with these words:

I stand here before you not as a prophet, but as a humble servant of you the people. Your tireless and heroic sacrifices have made it possible for me to be here today. I therefore place the remaining years of my life in you hands. ("Transcript of Mandela's," 1990, p. A15)

Being able to read his actual words served two purposes for the American public. First, it provided an opportunity for the reader to develop a better understanding of Mandela's position and second, and perhaps most influential in the development and perpetuation of his hero status, was that his words demonstrated just how mentally strong and determined Mandela was. His words supported previous pseudoevents in which he was cast in the role of a hero. Only hours after his release he stood firm in his demands and refused to back down from a government which managed, quite 
successfully, to silence him for 27 years. Mandela exemplified the description of the "messiah of the $80^{\prime} \mathrm{s}$ " (See Larson, 1989, p. 144). Mandela stated,

The factors which necessitated the armed struggle [in reference to the actions of the ANC's Umkouto We Sizwe] still exist today. We have no option but to continue. We express the hope that a climate conducive to a negotiated settlement would be created soon so that there may no longer be the need for the armed struggle...

Mr. de Klerk has gone further than any other Nationalist president in taking real steps to normalize the situation. However, there are further steps as outlined in the Harare Declaration that have to be met before negotiations on the basic demands of our people can begin. (p. A15)

Regarding universal suffrage and economic sanctions Mandela said,

To relax our efforts now would be a mistake which generations to come will not be able to forgive. The sight of freedom looming on the horizon should encourage us to redouble our efforts. It is only through disciplined mass action that our victory can be assured....

To lift sanctions now would be to run the risk of aborting the process toward complete eradication of apartheid. Our march to freedom is irreversible. We must not allow fear to stand in our way....

Universal suffrage on a common voters roll in a united democratic and nonracial South Africa is the only way to peace and racial harmony. ( $p$. A15)

I mentioned earlier that prior to Mandela's release

Burns (1990e) wrote an article which demonstrated a consistency in Mandela's philosophy and strength of will that spans a 27 year period (see p. 125). These traits were again demonstrated when Mandela, in the conclusion of his speech said, 
In conclusion I wish to go to my own words during my trial in 1964. They are as true today as they were then. I wrote: I have fought against white domination, and I have fought against black domination. I have cherished the idea of a democratic and free society in which all persons live together in harmony and with equal opportunities.

It is an ideal which I hope to live for and to achieve. But if needs be, it is an ideal for which I am prepared to die. (p. A15)

Mandela's role as a statesman was confirmed in various articles published during the week following his release ("Mandela unbound," 1990; Thurow, 1990d; "Washington wire," 1990a; "Washington wire," 1990b). In fact, Thurow (1990d) used the term "elder statesman" to describe Mandela.

According to the news reports, the U.S. government appeared to recognize and endorse Mandela's position as a statesman. Readers were told that President Bush was not in a hurry to lift sanctions against South Africa. Additionally, we were told that a bipartisan group of about 25 house members produced a proposal which outlined a "series of penalties and rewards that the U.S. might use to encourage South Africa to dismantle apartheid" (Greenberger, 1990). Given the title of this article, "Bush Says South Africa Sanctions stand, Retreating From Last Week's Remarks" it appeared that Bush did not want to appear to be in opposition to Mandela's wishes and was also under pressure from Congress to keep the sanctions intact.

Fuchsberg told readers that Mandela received not only an invitation from President Bush, but invitations from 
"...a half-dozen big-city mayors, Jane Fonda, [and] several universities to visit the U. S. (1990, p. A1). Specifically, Mandela was asked by Los Angeles mayor Tom Bradley to address "a rally for interracial harmony" to be held at the 92,000 seat Memorial Coliseum, site of the 1984 summer Olympic games (p. A1). Chicago's mayor also invited Mandela to visit, as did Duke University and the mayor of Detroit. We also learned that Senator Ted Kennedy called Mandela, and a delegation from Washington visited him in South Africa and extended an invitation to address a joint session of Congress. It appeared that everyone wanted "a piece" of Mandela. He was a celebrity. He was well known and was in demand. The above type of reporting accorded Mandela a degree of legitimacy which heightened his credibility.

During the months of March, April and May, 1990 the number of news reports which featured Mandela, began to taper off. Reports published during this period focused primarily on Mandela's actions, the situation in South Africa, and speculation as to if and when Mandela would visit the United States (Fuchsberg, 1990; Thurow, 1990C). However, these reports did provide readers with a sense of the tremendous burden that Mandela was saddled with. He was expected, by his own people and the international community, to be instrumental in ending black factional fighting, unite members of the ANC, and engage in power-sharing negotiations with the South African government while at the same time 
responding to an onslaught of invitations from various countries (Fuchsberg, 1990; Thurow, 1990C).

In June, 1990 the number of news reports featuring Mandela increased substantially. He would visit the U.S. for two weeks beginning June 20. News reports not only informed readers of the details of Mandela's visit, but reinforced his status as a hero and statesman which in turn laid the foundation for the warm welcome he was expected to receive (Kifner, 1990; Thurow, 1990b; Ungar, 1990; Wren, 1990a).

If for any reason a person was unaware of Mandela and his import these reports would be enlightening. For example, Wren, in his article titled "Mandela the Messenger:

Celebrated, Yet Life-Size," provided a brief biographical sketch of Mandela and described his current popularity in both South Africa and the U.S. (1990a). This article, along with Thurow's (1990b) were significant in that they made reference to the legend of Mandela while at the same time focused on the fact that he is, after all, a human being with human faults and frailties. This was important because it made it easier for the American public to identify with Mandela. Mandela was not a mythical character, the creation of an overly creative journalist; he is a real person.

Thurow's (1990b) article titled, "Mandela Legend Grows to Superhuman Proportions" told readers that Mandela "had been trying to climb down from the pedestal of his legend since the moment he stepped out of prison in February" 
(p. A17). In fact, in the opening paragraph he quoted Mandela as saying, "I am no prophet and it is not at all correct to elevate a human being to the position of a god" (p. A17). This quote serves to demonstrate Mandela's humility, modesty, and respect for deity, all qualities admired by the American public. And yet, Thurow indicated that even though Mandela sought to discount his importance he had become more popular than ever before. Thurow accounts for this popularity, in part, by saying that Mandela was "blessed with a "double-helping of charisma" and "shows no trace of bitterness" for his years of confinement (p. A17).

In the above article (Thurow, 1990b) and in Wren's article (1990a), readers are told that Mandela, since his release, had been traveling across Africa, to Europe, and North America and that all this traveling was beginning to take its toll. Mandela suffered from jet lag, got tired often, and was hospitalized for a week of rest and a "minor bladder operation" (Thurow, 1990b, p. A17).

On the other hand, Mandela is human. For example, we learned that he had "ruffled some feathers" (Thurow, 1990b, p. A17). Thurow writes,

His embrace of Yasser Arafat, the Palestine Liberation Organization Chief, irked the world's Jewish community; his tribute to Libyan leader Moammar Gadhafi's "commitment to human rights" raised eyebrows in the West; his early talk of nationalization dismayed the business community. (p. A17) 
In spite of these "ruffled feathers," the media told us that Mandela was immensely popular with the world community. Thurow wrote that Mandela, during his world tour, out-shined President de Klerk who had been traveling through Europe meeting with various heads-of-state (1990b). Thurow's article implied that there had been an undeclared contest between Mandela and de Klerk to see who could arouse the most support. Thurow declared Mandela the winner when he wrote,

But $M r$. de Klerk is no Elvis [implying that Mandela is]. Last week, Mr. Mandela campaigned through Europe--a mass rally here, tea with royalty there--and with this refrain, "I still have no vote," effectively recaptured the ground Mr. de Klerk had won. Mr. de Klerk had decided not to challenge $\mathrm{Mr}$. Mandela in the U.S., postponing a visit once scheduled for this month. (p. A17)

This clearly establishes Mandela as a celebrity, implying that Mandela is an "Elvis type" person, deserving of such recognition.

Mandela's celebrity status was further enhanced as news reports told Americans of the events scheduled for Mandela's U.S. visit. Under tight security Mandela would be welcomed to New York with a ticker-tape parade. While in New York he would tape television programs, would meet with various city officials and community leaders, and would attend rallies in Harlem and Yankee Stadium. As Mandela moved throughout the country he would, among other things, meet with President Bush and address a joint session of Congress. He was expected to receive a warm welcome when he visited 
Washington, D.C., Detroit, Oakland and Los Angeles (Fuchsberg, 1990; Kifner, 1990; Thurow, 1990b; Wren, 1990a).

On the morning of June 21 Americans awakened to find photos of Mandela and headlines heralding his arrival splashed across the front pages of newspapers across the country. Mandela, the hero and celebrity, had arrived in the United States!

\section{NARRATIVES AS GUIDES TO BELIEF AND ACTION}

\section{Cultural Myths and value orientations}

Consistent with Chapter IV, this section deals primarily with the presence of cultural myths and values in the media reports of Mandela. News reports from 1985 to mid1989 laid the ground work for the full development of the Coming of a Messiah myth in the period discussed in this chapter.

Coming of a Messiah. In the media coverage of Nelson Mandela from January to June, 1990, we see the development and perpetuation of a cultural myth in the United states that is an extension of a myth previously developed in South Africa among the black community. This is the Coming of a Messiah myth. As the American public learned more about the existence of the legend of Mandela in South Africa they were invited by the media to join South Africans in the actualization of the Coming of the Messiah myth. The myth centers around a belief that people want and need to be 
rescued from a situation that is unbearable, chaotic, confusing, and/or frightening (Larson, 1989). This myth reflects the value Americans place on order, progress, the future, social good, and security.

In South Africa the rescuer or messiah (savior) was Nelson Mandela. In the articles reviewed, Mandela was depicted as the one person who could end apartheid and bring democracy to his country. McFadden wrote, "...the man once regarded by white South Africans as a threat to everything they prized had become the best, perhaps last hope of peaceful reconciliation" (1990, p. A16). Kraft (1990b) told readers that Mandela was viewed as a "Moses" in the black community. He told us that Mandela was, "...a figure of almost mythical proportions among South Africa's black masses, millions who have never seen or heard him" (p. A14). Much like Moses, who is depicted as a messiah in the Bible, in this article Mandela is cast in a similar role; he is the one who can free his people. And Thurow (1990e) wrote that "The African National Congress expects him [Mandela] to be a messiah, bringing the organization to power after 78 years of frustrating struggle" (p. A1). Kendal wrote,

Black South Africans, regardless of the language they speak or the value system they espouse, whether they are urban businessmen or traditional rural tribesmen, are largely united in their belief that Mr. Mandela will be the man who leads them to liberation. (1990, p. 14)

The media was successful in creating an image of Mandela as the messiah of black South Africans by 
continually reaffirming his status as a hero among black

South African's and his world followers. McFadden described Mandela as he walked out of prison in the following passage,

The face was like parchment and the voice was strained, but the passion was still there: power seemed to radiate from the lean old figure. And anyone could see that the years of prison had ravaged only the body, not the spirit; they had, if anything solidified his resolve and raised his stature as the embodiment of black liberation. (1990, p. A16)

In June, 1990 journalists made reference to Mandela's status in South Africa and abroad. Thurow wrote,

Wherever the 71-year-old African National Congress leader goes...curious multitudes strain to see, touch and hear him. He may not be a god, but Nelson Mandela... is certainly an extraordinary idol... The Mandela legend--the unbowed prisoner refusing to compromise his principles prevails. (1990b, p. A17)

Smith claimed that even some South African whites see Mandela's role as a messianic one when she wrote, "Many see him as the man to save them [white South Africans] from the tyranny of the masses [meaning blacks]," (1990, p. M2).

Mandela's concern for the white minority was demonstrated when it was reported that he wrote that the sharing of political power with blacks would include "structural guarantees that majority rule will not mean domination of the white minority by blacks" ("Yes to Mandela," 1989, p. 26).

An interesting deviation from typical stories of Mandela and his relation to white South Africans reached the American public on February 4, 1990. Prior to this the 
public doesn't read much in U.S. news reports regarding white South African reaction to Mandela's pending release. Smith addressed this issue when she wrote,

Many see him as the man to save them [white south Africans] from the tyranny of the masses. He has developed an image of great fairness and, remarkably, the whites who jailed him for 27 years trust he will intervene to protect white power bases. They base their hope on the fact that the 73-year-old prisoner has facilitated extensive pre-negotiations between the ANC and the government. (1990, p. M2)

Not only did Mandela become a symbol of peace and freedom for black South Africans, he became a "protector" for whites. The article conferred upon Mandela a legitimacy previously lacking. He became the messiah for all the people, not just blacks.

Larson (1989) believes that people who are perceived by others as being "messianic," capable of rescuing them, are seen as being action oriented (p. 226). He claims that "The messiahs of the 1980's...have been hard-nosed, bite the bullet types...the no-nonsense type who seemed to be saying 'enough is enough!' as they drew a line in the dust and dared the opposition to cross" (1989, p. 226). In other words these are individuals who possess the attributes of courage, charisma, strength, and determination; all of which are valued in the American culture. Wren's lead paragraph reads,

After 27 and a half years in prison, Nelson Mandela finally won his freedom today and promptly urged his supporters at home and abroad to increase their pressure against the white minority 
Government that had just released him [italics added]. (1990b, p. A1)

Mandela was only out of prison for a few hours before he was telling the world that he would honor the conditions for negotiations with the South African government as outlined in the Harare Declaration. He also reaffirmed his commitment to the ANC. In regard to violent protests he stated, "The factors which necessitated the armed struggle still exist today. We have no option but to continue" ("Transcript of Mandela's," 1990, p. A15). Clearly, Mandela has drawn "a line in the dust" (Larson, 1989, p. 226).

Presence of a conspiracy. The role of the messiah in the Presence of a Conspiracy myth (See p. 103), is that of savior. The messiah is seen as having the power to "defeat the evil conspirators and thus save the culture" (Larson, 1989, p. 227). McFadden wrote, "Indeed, as with Gandhi, Andrei D. Sakharov and other prisoners of conscience, confinement had served only to burnish his legend and preserve the flame of rebellion, until the silenced renegade came at last to tower over his oppressors" (1990, p. A16). And Thurow wrote, "Standing triumphantly on the steps of Cape Town's glorious old city hall, Mr. Mandela waved his fist and shouted 'Amandla'" [power] to the people (1990C, p. A1). In these narratives Mandela was depicted as the one person capable of crushing the conspiracy.

Value of Challenge. As with the Conspiracy myth, the Value of Challenge myth (See $p$. 106) continues to be alluded 
to immediately prior to, and following Mandela's release. Readers are continually reminded that Mandela has faced seemingly insurmountable obstacles in his fight for racial equality; he has been banned, hunted, and imprisoned. And yet he has risen to the challenge and has won (Burns, 1990c; Kraft, 1990a; McFadden, 1990; Thurow, 1990b).

Even though Mandela's release was depicted as a victory for both Mandela and the anti-apartheid movement, the media suggested that he would face an even greater challenge. Burns wrote,

With many South Africans, whites as well as blacks, inclined in recent weeks to see Mr. Mandela as a colossus, who can somehow resolve the nation's political problems, it was a reminder that what lies ahead would be daunting for any man, let alone one who has spent more than a quarter of a century largely cut off from the world. (1990a, p. Al4)

Mandela was expected to end factional fighting. Thurow wrote, "For his part, Mr. Mandela faces perhaps his most difficult challenge in bringing together a disparate and feuding range of black organizations" (1990e, p. A7). According to Fuchsberg (1990) Mandela also faced the challenge of juggling his celebrity status and demands for public appearances around the world with his duties and commitments to the ANC. Regarding his visit to the U.S., Ungar states that the "big challenge for Mandela" was to persuade, "...Americans to listen to some of his ideas for South Africa's future, rather than simply seeing that complex and troubled country as one more place to export our 
system of government $(1990, \mathrm{p}$. M5). As the above examples demonstrate, reference to the Value of Challenge myth was continually woven into the media narratives in the months following Mandela's release.

Value Orientations. In Chapter IV my discussion of values focused on the Enlightenment value system as the dominant system found in the news reports of that period. During this period elements of the Progressive and Collectivist value systems are prominent.

As I mentioned in Chapter IV (See p. 116), it is essential that the media provide evidence that Mandela embraces primary American values if his hero persona is to be seen as credible to the reader. During the period covered in this chapter, news reports demonstrated that Mandela and the American value systems, as identified by sillars (1991), were consubstantial with the central purpose of the master narrative, which was to achieve a free democratic society in South Africa.

According to Fisher character is central to all stories. He writes that,

Whether a story is believable depends on the reliability of characters, both as narrators and actors. Determination of one's character is made by interpretations of the person's decisions and actions that reflect actional tendencies. If these tendencies contradict one another, change significantly, or alter in "strange" ways, the result is a questioning of character. Coherence in life and in literature requires that characters behave characteristically. (1987, p. 47) 
Reference to Mandela's personal value orientations can be found in several articles published immediately prior to his release. These articles suggested that Mandela embraced many values found in the Progressive, Collectivist, and Enlightenment value systems. Reference to these value systems through descriptions of his actions, direct quotes, and his associations with others contributed to the development of the hero persona. The stories were believable because they demonstrated a consistency between Mandela's value orientations and his actions. The following discussion of value systems includes descriptions of Mandela's value orientations as found in the media reports.

Progressive Value System. Sillars (1991) claims that this value system is closely related to the Enlightenment system and is based on the idea that progress is essentially good. The problem or question associated with this system is in defining the term "progress." In the news reports reviewed "progress" appeared to mean, or refer to, the peaceful movement toward democracy and racial equality. Terms that reflect the Progressive value system include: change, efficiency, evolution, future, improvement, progress, and modern (Sillars, 1991).

In several of the articles reviewed, a preference for change versus maintaining the status quo in South Africa was demonstrated as journalists wrote about forces that resisted peaceful negotiations between Mandela and the ANC, and the 
South African government. Resistance to change was often described in negative value terms.

Kraft and Cart wrote that within days of Mandela's release 10,000 white South Africans marched in protest of his release. Included in the article were examples of signs held by many white marchers. Some said, "The New South Africa: Farewell Whites;" "Hang Mandela;" and "27 years a bandit, Now a Hero." (1990, pp. A1, 11). The journalists wrote that many whites feared Mandela and steps taken by de Klerk such as legalizing the ANC. Quotes from Mandela, found in this article, include the following:

We are prepared to address the fears of whites.... Without their cooperation, we will have immense problems in this country. That is why we are so keen to give them guarantees that the changes we are demanding are not going to mean domination of whites by blacks. (pp. A1, 11)

Here, Mandela was suggesting that blacks and whites must work together to resolve their differences. This attitude was quite different from the attitudes of those whites mentioned in the article. Note the contrast between how whites were described and what Mandela was quoted as saying. The suggestion was that many whites were resisting change and progress (a negatives value) while Mandela embraced it (a positive value).

This article also demonstrates a difference in how progress was defined. Mandela was quoted as saying, "Once he [de Klerk] concedes that majority rule will be the solution, the African National Congress is prepared to address the 
fears of whites... [change] will not mean that their standards will worsen (Kraft \& Cart, 1990, p. A11). Mandela saw change as a positive thing, but according to Kraft and Cart many whites saw change as a threat to their personal well being with many whites demanding a "separate white homeland" (p. A11). Within this context, Mandela was portrayed as the protagonist or hero and white protestors were portrayed as the antagonists or villains.

Thurow's article provides another example of resistance to progress. The underlining of words is mine. Thurow wrote,

Fear and loathing stalk South Africa's conservative heartland these days. The whirlwind of change that has swept the country in the past few days has inflamed the passions of the white right. Pride. Prejudice. Defiance. Desperation. First came the unbanning of the African National Congress, then the release of ANC leader Nelson Mandela, the beginning of power-sharing talks with the blacks. Now, Mr. Mandela is triumphantly circling the world, arriving in New York tomorrow to a ticker-tape parade. As the walls close in on white-minority rule and the cozy privileges of apartheid, right wing emotions, so raw and intense, threaten the "new" South Africa with a level of racial violence unknown even in the old one. (1990a, p. A1)

Several things come to my attention when reading this excerpt. First, Thurow, with his creative use of the words "fear," "loathing," "stalk," "inflamed," "cozy privileges," "raw," "intense," and "violence," as he described the feelings of white conservatives and the emotional climate of South Africa, has implied that conservative whites are adamantly opposed to any kind of change in their country which would alter their current position in society. Second, 
he alluded to the source of this negative attitude when he described the privileges whites enjoy under the current system of apartheid as "cozy." It seems reasonable that anyone who enjoys "cozy" privileges would be resistent to change. Third, Thurow also suggested that this is an undesirable attitude when he described whites feelings in such negative terms. He implied that if whites don't change their attitudes and become more cooperative there would be continued unrest and violence. Lastly, Thurow (1990a) suggested that Mandela and the ANC had the support of the international community when he described Mandela's tour of the world as "triumphant" and reported that a ticker-tape parade awaited him in New York.

The article, ("Transcript of Mandela's," 1990) provides an excellent example of Mandela's adherence to the Progressive and Enlightenment value systems. Throughout his speech Mandela continually made reference to freedom, democracy, progress, change, and the future, terms often used to represent these systems (Sillars, 1991).

Media support for these values and Mandela was reflected in numerous articles published during the days following his speech. In these articles excerpts drawn from Mandela's speech dealt primarily with Progressive and 
Enlightenment values. For example, in his speech Mandela stated,

My friends, comrades and fellow South Africans, I greet you all in the name of peace, democracy and freedom for all....

Negotiations on the dismantling of apartheid will have to address the overwhelming demand of our people for a democratic nonracial and unitary South Africa. The must be an end to white monopoly on political power...

Negotiations cannot take place above the heads or behind the backs of our people. It is our belief that the future of our country can only be determined by a body which is democratically elected on a nonracial basis. ("Transcript of Mandela's," 1990, p. A15)

These statements are also found in McFadden (1990), Burns (1990a), and Wren (1990b) respectively. The journalists selectively chose to focus on sections of Mandela's speech which alluded to the above value systems.

In both the transcript of Mandela's speech ("Transcript of Mandela's," 1990) and other articles, Mandela, and journalistic reports of Mandela, often made reference to the future (a progressive value term) (McFadden, 1990; Thurow, 1990a). Mandela made predictions about what he expected to happen, and expressed opinions about what must happen, if South Africa was to have peace. As mentioned earlier (Chapter IV) the theme of peaceful change, a moving forward toward a democratic future, was continually emphasized. Reference to the past was made only in terms of how past events had influenced the present situation and how past events may impact the future. Mandela also made reference to the past in an attempt to demonstrate a consistency in his 
value orientations and political position. The following example illustrates this relationship between the past and the future. In his speech at Cape Town Mandela stated,

The apartheid destruction on our subcontinent is incalculable. The fabric of family life of millions of my people has been shattered. Millions are homeless and unemployed.

Our economy--our economy lies in ruins and our people are embroiled in political strife. Our resort to the armed struggle in 1960 with the formation of the military wing of the ANC, Umkonto We Sizwe, was a purely defensive action against the violence of apartheid.

The factors which necessitated the armed struggle still exist today. We have no option but to continue. We express the hope that a climate conducive to a negotiated settlement would be created soon so that there may longer be the need for the armed struggle. ("Transcript of Mandela's," 1990, p. A15)

In the above passage Mandela was, in essence, saying that he values peace, but not at the expense of freedom and he indicated that he valued family and a progressive economy (all valued in America). He placed the responsibility for the political, social, and economic problems of the past and present directly on the non-democratic system of apartheid.

The editorial "Mandela's Cry of Freedom" illustrates media support for the value Mandela placed on the future and his vision of a democratic state with the statement, "With eloquence and vision, he [Mandela] looks beyond the bondage of apartheid to the 'establishment of democracy' on 'a nonracial basis" "(1990, p. B6).

Collectivist Value System. This system is based on a belief that collective action can benefit society (sillars, 
1991). The theme of cooperative action, as a positive value, and one embraced by Mandela, is evident in an article by Thurow (1989a). In the lead paragraph Thurow wrote, "Nelson Mandela, the imprisoned leader of the African National Congress, said negotiations between the government and his banned organization are the 'only way' to bring peace to South Africa" (p. A10). Thurow endorsed Mandela's position and suggested that cooperative, collective action was the only viable option for peace when he wrote, "...Mr. Mandela's emphasis on dialogue and peace likely will increase the pressure both sides are facing from their own constituencies, as well as many foreign governments, to edge closer to the negotiating table" (p. A10).

Mandela's adherence to the Collectivist value system was further demonstrated in various news reports written throughout this period (Burns, 1990a; Burns, 1990b; Burns, 1990d; Kendall, 1990; MCFadden, 1990; Thurow, 1990a; "Transcript of Mandela's," 1990; "What Mandela wants," 1990). Note that the term "Collectivist" need not imply communist. As demonstrated in the following examples, Mandela is espousing "democratic" notions of collective action.

The most obvious evidence of Mandela's Collectivist value orientation can be found in articles that reproduced speeches and statements made by Mandela after his release. The best example of this is the transcript of Mandela's 
speech made on February 11 (the day of his release) and published in The New York Times on February 12 ("Transcript of Mandela's," 1990). The underlining of words is mine. In this speech Mandela tells his audience,

I extend special greetings to the people of Cape Town.... Your mass marches and other forms of struggle have served as a constant source of strength to all political prisoners...

I salute the rank-and-file members of the ANC. You have sacrificed life and limb in the pursuit of the noble cause of our struggle...

I salute the United Democratic Front, the National Education Crisis Committee, the South African Youth Congress, the Transvaal and Natal Indian Congresses. And Cosatu. And the many other formations of the mass democratic movement.

I also salute the Black Sash and the National Union of South African Students. We note with pride that you have acted as the conscience of White South Africans. Even during the darkest days in the history of our struggle, you held the flag of liberty high. The large-scale mass mobilization of the past few years is one of the key factors which led to the opening of the final chapter of our struggle.

I extend my greetings to the working class of our country. Your organized stance is the pride of our movement. You remain the most dependable force in the struggle to end exploitation and oppression.

I pay tribute--I pay tribute to the many religious communities who carried the campaign for justice forward when the organizations of our people were silenced....

On this occasion, we thank the world--we thank the world community for their great contribution to the anti-apartheid struggle. Without your support our struggle would not have reached this advanced stage. (p. A15)

In the above passages Mandela's use of the terms, "I salute," I extend greetings," "I pay tribute," "our," "mass democratic movement," "mass mobilization," and "organized stance" reflect his value for cooperative action and 
demonstrate his support for those who engage in such action. It is clear that Mandela believed that the struggle for freedom depended on people who were willing to work together for the social good. The fact that he addressed many groups and individuals ( $I$ only mentioned a few) in the first few minutes of his speech indicates that he saw all of these diverse groups as one massive group seeking the same goal: achieving racial equality (a fundamental American value).

It is also apparent in this article that Mandela saw cooperative action as the only means of achieving democracy. He stated that,

Today the majority of South Africans, black and white, recognize that apartheid has no future. It has to be ended by our own decisive mass actions in order to build peace and security. The mass campaigns of defiance and other actions of our organizations and people can only culminate in the establishment of democracy. ( $p$. A15)

\section{SUMMARY}

Consubstantiality (also referred to as identification) refers to the common ideas, attitudes, possessions or properties that one individual shares with another individual (Burke, 1969). Consubstantiality occurs when individuals identify and share these common ideas, attitudes, etc. (via language) with others. As we use symbols to identify our consubstantiality those symbols become significant in that they allow us to achieve shared meaning (Foss et al., 1985). The significant symbols 
represent one's consubstantiality and through communication of these symbols our identification with others can increase. As we increase identification, persuasion increases. Burke states, "You persuade a man only insofar as you can talk his language by speech, gesture, tonality, order, image, attitude, idea, identifying your ways with his" (1969, p. 55). It then becomes easier to persuade someone to adopt our position or accept our ideas or argument when we use symbols that establish our consubstantiality with our target audience. The U.S. print media has done just that by using language that represents, or refers to, commonly held American values and cultural myths. They have engaged in the selective reporting of Mandela's words and actions within a mythic context wherein he is depicted as a hero who embraces such values. The act of associating characters (heros, villains, and supporting characters) with commonly held American values contributes to the development of consubstantiality or identification between the reader and the journalist, and the reader and the characters in the narrative.

Value orientations can and often do function as "good reasons" or "warrants" for the acceptance or rejection of a particular narrative (See p. 40). Among other things, Fisher claims that "reasons" are good when they are perceived as, "true to and consistent with what we think we know and what we value, consistent with what we believe is an ideal basis 
for conduct" (Fisher, 1987, p. 194). If we accept Fisher's claim then it seems logical that news stories which are consistent, in their portrayal of events and characters, with what we think we know and what we value are more likely to be accepted than stories which cause us to question not only the story, but our perceptions of the characters and scene. A pattern exists among the news reports of this period that is very consistent with the one established in the previous period.

The practice of incorporating cultural myths with their underlying value structure into the media narratives contributes to the believability of the narratives in that there is a consistent thread which binds the narratives together to form a coherent picture of South Africa and its key figures. The inclusion of belief statements and terms which make reference to American values, or the lack thereof in South Africa, contributes to character development. The "good guys" are those who embrace primary American values and the "bad guys" are those who don't. During this period, changes in a character's values orientations, if they occur, do so gradually. This also contributes to the believability of the narrative in that it allows the reader to adjust their perceptions gradually. The reader is not asked to make any cognitive leaps which may result in them experiencing dissonance. For example, from 1985 to mid-1989 the south African government, with Botha as its president, was 
reported as being quite rigid in their enforcement of apartheid (see pp. 107-109). However, during the period discussed here, journalists described what appears to an evolution in policy by the South African government. Media reports suggested that the South African government was moving in the direction of embracing what Sillars (1991) calls the Enlightenment value system. Thurow stated,

In freeing Mr. Mandela, the de Klerk government has also curiously freed itself. It was the ANC's leader's continued incarceration that always made a sham, in the eyes of many, of this government's repeated attempts to proclaim apartheid's death. Now Mr. de Klerk's proclamation of a new South Africa has a more sincere ring, denying the sanctions lobby its most emotional rallying point. The release lends credibility to Mr. de Klerk's claim that this door is open; he hopes that as Mr. Mandela walks through, others will surely follow. (1990e, p. A1)

Instead of being in direct opposition to one another, the South African government (particularly de Klerk) and the anti-apartheid movement were portrayed as being more willing to engage in peaceful negotiations. The above action was widely praised by western nations (Around the World," 1990; Burns, 1990b; Farnsworth, 1990; Lyal1, 1990; Thurow, 1990e). The inclusion of positive responses from individuals who can be assumed to hold primary American values serves to suggest to the reader that actions taken by the South African government indicate positive change. After all, if our leaders support these actions, and we assume they hold the same values we do, then should not we also be supportive? 
Additionally, via news reports, readers learned about the response of others to Mandela's release and plans for his visit to the U.S. ("Around the world," 1990; Lyall, 1990). These reports provided readers with an opportunity to evaluate these responses in terms of their own images of Mandela and if necessary adjust their perceptions, so that they are consistent with individuals with whom they can identify. In other words, if a reader learns about the positive responses of others to Mandela, and these people are seen as possessing similar beliefs and values then it is possible that the reader will come to embrace the same beliefs regarding Mandela. For example, I can identify with (I am consubstantial with) individuals who believe in equal rights for all persons regardless of race. Mandela, as portrayed in many of Thurow's articles, appears to believe in equal rights for all, regardless of race. Therefore, it is relatively easy for me to identify with both Mandela and Thurow.

\section{PREVIEW OF CHAPTER VI}

The following chapter concludes this study with a summary of results and implications. Suggestions for future research are presented. 


\section{CHAPTER VI}

CONCLUSION

\section{INTRODUCTION}

Throughout this study it has been my purpose to examine the U.S. print media's contribution to the development of Nelson Mandela's public persona during the period of 1985 to June, 1990. With this goal in mind, I have described and evaluated the way in which the media constructed its messages to present an image of Mandela as both a hero and celebrity for the American public. Additionally, I have identified and evaluated the inclusion of and/or reference to cultural myths, as well as their underlying values in the media reports. I have explained how they serve as the interpretative framework for public belief and action. I have demonstrated how these news reports, through their content and form invite the reader to accept, believe in, and support Nelson Mandela and his cause.

In this chapter, I summarize the results of my research, discuss some implications suggested by this study, and present some possibilities for further research. 


\section{SUMMARY}

In 1990 Nelson Mandela occupied a unique position in the political and social arenas of South Africa and the world. He came to be recognized as an international symbol of equality and freedom.

As mentioned earlier (See p. 74), during the period studied, there were two distinct phases in the development of Mandela's public persona in the U.S. print media. In the first phase (1985 to mid-1989) Mandela was portrayed as an instrument of change as journalists speculated on the possibility of his release from prison. Additionally, during this period the media introduced its readers to the concept of Mandela as a hero of black South Africans. As this phase progressed Mandela's role changed when the media bestowed on him the role of co-agent/actor by associating him with prominent political figures in both South Africa and the United States. The master narrative concluded on a note of suspense: Will Mandela be released, and will he be allowed to participate in the reshaping of the South African scene?

The second phase of the master narrative (mid-1989 to June, 1990) marks a period in which Mandela's hero persona and celebrity status reached full development. During this phase Mandela was depicted as the pivotal force in the changing South African landscape. From mid-1989 to June, 1990 Mandela, as the central actor in the media narratives, was transformed from actor to scene. Mandela was elevated to 
a position that portrayed him as the "savior" of millions of black South Africans. He came to personify not only millions of black South Africans, but the entire political/social scene of South Africa.

The media engaged in several practices which contributed to the development of the public persona of Nelson Mandela. The most significant of these practices were: 1) the introduction of Mandela as not only a legend, but a hero among black South Africans; 2) the practice of surrounding Mandela with mythical reference; 3) the establishment of Mandela as an individual who subscribes to many traditional American values and; 4) the serial reporting of pseudo-events. These practices, working together, serve to guide and shape readers perceptions of Mandela and the South African landscape.

\section{IMPLICATIONS}

Schudson argues that the media uses conventions of narration to present information in a form that is unquestioned by the public. He suggests that,

...the power of the media lies not only (and not even primarily) in its power to declare things to be true, but in its power to provide the forms in which the declarations appear. News in a newspaper or on television has a relationship to the "real world," not only in content but in form; that is, in the way the world is incorporated into unquestioned and unnoticed conventions of narration, and then transfigured, no longer a subject for discussion but a premise [italics added] of any conversation at all. (1982, p. 98) 
Schudson's use of the word "premise" implies that the reader/audience who uses a particular report as a basis or reference point. for conversation and/or action has accepted that report as being an accurate reflection of reality. That is not to say that the person necessarily agrees with the positions taken by the characters, but only that it furnishes reliable information. When this information is couched in the narrative form, with a "recognizable plot of action which sets character against character" (Sperry, 1981, p. 303), the reader is more likely to "get caught up in the drama," (Bormann, 1985, p. 130). According to Symbolic Convergence theory, "If one or more of the leading characters is found attractive [by an audience member], the result is the arousal of at least sympathy or, if more strongly pulled, empathy" (Bormann, 1985, p. 130). Conversely, if another character in the narrative is portrayed as the antagonist, one who seeks to hinder the goals of the protagonist, the emotional response is likely to be negative (Bormann, 1985). Media reports of Mandela used the narrative form to cast Mandela in the role of the hero. Continually Mandela was portrayed as a hero with laudable goals who must overcome the antagonist, the South African government.

Bormann tells us that,

When members of a mass media audience share a fantasy [dramatic message] they jointly experience the same emotions, develop common heroes and villains, celebrate certain actions as laudable, 
and interpret some aspect of their common experience in the same way. (1985, p. 131)

The response of the American public to Mandela's release and subsequent arrival in the United States suggests that a substantial number of Americans shared a similar social reality, a similar perception of Mandela; they achieved a "symbolic convergence." The U.S. print media, provided readers with an opportunity for identification via the use of mythic structures underlying the master narrative. The media was successful in bringing foreign events into the realm of American mythic tradition. Foss, et al claims,

Identification or persuasion results from an interaction of form and content. Through involvement in its form, a rhetorical work induces tensions or expectations with which the audience identifies, when the rhetor resolves the tension and creates some sort of resolution in the work, the audience views the work's resolution as its own. (1985, p. 163)

In these narratives pseudo-events functioned to produce varying degrees of tension between elements. Specifically, Mandela was depicted as a "man of peace," in a troubled society, whose efforts to achieve equal rights for black South Africans were being thwarted by a repressive government. During both phases of the master narrative a tension existed between Mandela (and his values) and south Africa's political elite. Resolution in the master narrative was achieved when Mandela came to dominate the narrative as not only the symbolic representation of millions of black 
South Africans, but also the symbolic representation of the value place on peace, justice, and equality. Pseudo-events, which in essence are scenarios of what we should expect to see happen in the future, were repeated over and over again in the news reports. They contribute to resolution in the master narrative. The pseudo-events, with their predictions of the future, provided a foundation for reader expectations. In other words, the media, in many of its reports of Mandela, forecasted the future and in doing so wove a thread of consistency throughout its stories. Hence when comparing news stories from within and between the two phases identified, we see that, as a whole, the stories "hang together" (Fisher, 1987, p. 194). The stories are relatively free of contradictions. Parenti writes,

The press can effectively direct our perceptions when we have little information to the contrary and when the message seems congruent with earlier notions about events--notions that themselves may be partly media created. In this way the new information is a reinforcement of earlier perceptions. (1993, p. 23)

If a reader comes to expect certain events to occur in the future based on her understanding and/or acceptance of earlier news reports then the news report has been effective in shaping that readers perceptions.

How did the narratives of Mandela serve as the interpretative framework for belief and action? They 
achieved "mythic adequacy" (Lawrence \& Timberg, 1979, p. 326). Lawrence and Timberg posit,

In short we must conclude that mythic adequacy is one important criterion of newsworthiness. 'Mythic adequacy' here means the degree to which the features of an event conform to the preexisting features of a mythic paradigm.

More generally we may observe that to the extent that particular sets of facts reflect the confirmation of mythic fantasy, they promise to achieve greater dominance and durability in the public's news consciousness. News stories that are "Mythically adequate" not only tell us something about the world of events. They also provide confirmation for the faith that we can be finally victorious over the forces that besiege us. Certain kinds of news stories thus take on the character of a ritually structured affirmation of hope. Perhaps the institutions of news, which often style themselves as the enemies of myth, are one of the principal means through which myths are subtly restated and given renewed vitality. (1979, p. 328)

In the mid 1980's journalists introduced the "Presence of Conspiracy," the "Value of Challenge," and the "Coming of a Messiah" myths into their writings. They continued to weave these myths throughout their reports and in February, 1990, when Mandela was released, the myths were shown to be an accurate reflection of reality. The chain of events which unfolded in the new reports, beginning with the possibility that Mandela would be released, supported several premises found in the above myths. For example, if one is challenged (Mandela has been involved in a life-long struggle with the South African government) and he perseveres (Mandela never gave up), he will succeed (Mandela was released to become a vital force in the restructuring of South Africa). Messiahs 
do exist, Mandela has come. The news reports were mythically satisfying.

Lustig claims that narratives, in all their various form (including U.S. print media), continually reinforce (directly or indirectly) American values that generally go unnoticed or unquestioned by the majority. And yet, "a culture's values provide the basic set of standards and assumptions that guide thought and action" (1988, p. 56).

The implicit and explicit reference cultural myths and values, identified in this study functioned as sanctioning agents (authority or ideal) that supported or justified Mandela's position and actions. American newspapers indirectly endorsed Mandela's political philosophy and policies when they structured their reports in a way that reflected positively on Mandela. This was accomplished, in part, by describing his philosophy and policies in positive value terms and by surrounding Mandela with mythical reference. As Mandela was transformed from actor to scene he became the mythical context (the Coming of a Messiah) in which all other elements of the narrative were framed. By demonstrating that Mandela's value structures were consubstantial with many traditional American values the media was able to establish him as an individual worthy of public support. Additionally, the media indirectly demonstrated its support of Mandela in the way the stories were framed. In the news reports studied I found no 
instances where Mandela's values or motives were called into question. This practice was in marked contrast to references made to the South African government's motives. Continually its motives were questioned. The media's portrayal of Mandela was consistently positive.

In comparing heroes and celebrities Boorstin writes,

The hero was born of time: his gestation required at least a generation.... He grew over the generations as people found new virtues in him and attributed to him new exploits.... It was not necessary that his face or figure have a sharp, well-delineated outline, nor that his life be footnoted.... The celebrity, on the contrary, is always a contemporary. The hero is made by folklore, sacred texts, and history books, but the celebrity is the creature of gossip, of public opinion, of magazines, newspapers, and the ephemeral images of movie and television screen. The passage of time, which creates and establishes the hero, destroys the celebrity. One is made, the other unmade, by repetition. The celebrity is born in the daily papers and never loses the mark of his fleeting origin. (1961, p. 63)

In the narratives of Mandela the media first recognized him as a hero and later, accorded him celebrity status. Mandela was identified as a hero who was "distinguished by his achievement" and later a media created celebrity with a "big name" (Boorstin, 1961, p. 61).

The year is 1993, Nelson Mandela, president of the ANC and recent recipient of the Nobel Peace prize, is still actively involved in negotiations for a new constitution with the South African government. The media periodically publishes reports of both these negotiations and continued factional fighting and civil unrest in South Africa. The 
country's first multi-racial election is scheduled for April, 1994 (Associated Press, 1993). Mandela's role in these reports is no longer that of scene or key agent/actor. And even though many speculate that he will be the next president of South Africa he has resumed the role of coactor/agent along with President de Klerk. Boorstin writes that,

Just as real events tend to be cast in the mold of pseudo-events, so in our society heroes survive by acquiring the qualities of celebrities. The best-publicized seems the most authentic experience. If someone does a heroic deed in our time, all the machinery of public information-press, pulpit, radio, and television--soon transform him into a celebrity. If they cannot succeed in this, the would-be hero disappears from public view. (1961, p. 66)

In the strict sense of Boorstin's definition of celebrity (See p. 28), Mandela may no longer meet the criteria for celebrity status in the media. But we do know that the media played a significant role in establishing Mandela as both a hero and celebrity for their conventional audience from 1985 to June, 1990. As demonstrated in this study we have seen how the media can create "wellknownness." Sperry writes,
"Aristotle was hard put to explain it, and nobody after him has managed to clarify whether emotions are purged or incited by narrative presentation. What TV [also print] newsmen do know is that stories given to the depiction of elemental human dilemmas will galvanize emotion, and they will attract and maintain an audience" (1981, p. 307).

However, in order for a narrative to be seen as believable, in order for it to be accepted, the "character" or 
"integrity" of the narrative must be established. Lucaites and Condit claim that in dialectical narrative (e.g., news reports) the audience makes an assumption that the speaker "has no self-interest in the narrative, and his or her credibility is theoretically presumed... it is assumed that the story itself will remain objectively the same, whoever tells it" (1985, p. 102). Several problems occur in making such an assumption. First, news reports are not strictly dialectic. As Lucaites and Condit argue, they do contain elements of the poetic and rhetorical. The creation of pseudo-events is illustrative of the poetic form. Pseudoevents may relate verifiable historical facts, but they also function to entertain and persuade. Second, the reports of Mandela exemplify the existence of homogeneous news. We have a relatively few reporters writing the bulk of the reports on foreign affairs. These news reports are relatively free of contradictions. Finally, though journalists are "outside the narrative itself" (Scott, 1984, p. 199) they are still narrators in that they play a critic's role when they "construct" rather than just "transmit" historical events via news reports. What this means is that the reader is not getting an unbiased, objective view of reality. The narrative she reads is a creation of the journalist whose reporting is structured by a variety of factors such as: journalistic conventions, personal interpretations and biases, and social guidelines. 
We are, as Graber says, "at the mercy of the media" for both information about and the interpretation of "complex national and international issues (1984, p. 142). Under the guise of objectivity, the media uses the narrative, with all its persuasive appeal, to shape a reader's perceptions. The use of the traditional pyramid style, the inclusion of implicit value statements, and the exclusion of overt displays of personal opinion are familiar to readers and hence confirm a reader's expectations that the news story is accurate and unbiased.

The media abuses the public trust when it takes advantage of that trust to create a constructed reality that serves its own interests. I agree with those critics who claim that the media has political and economic motives which drives it to construct narratives that serve the special interests of the power elite.

Two factors are at work here which may account for the way in which the media, either consciously or unconsciously, developed Mandela's public persona. First, was the need to satisfy public demand for interesting, exciting news, and second, the need to protect the interests of the power elite who have controlling interests in the newspaper corporations.

Newspaper corporations are in business to make money. In order to make money they must maintain a reader audience. How can they do this? One way, according to Boorstin, is to 
meet readers demands for sensational news (1961). Boorstin claims that we (Americans) are "ruled by extravagant expectations," and that these expectations are partially responsible for the way the media structures its reports (1961, p. 3). In an attempt to avoid the "deadly repetition" of news" and meet public expectations, Boorstin claims that the media creates pseudo-events (1961, p. 14). This has resulted in what is now the standard practice of making news rather than just gathering news. In other words, news stories are written and published for the ostensive purpose of attracting reader attention. However, the media must also protect its corporate interests. Bagdikian writes,

The news media are not monolithic. They are not frozen in a permanent set of standards. But they suffer from built-in biases that protect corporate power and consequently weaken the public's ability to understand forces that create the "American Sense." (Bagdikian, 1987, p. XV)

In Chapter I (See pp. 10-12) I discussed the relationship between media corporations and U.S. business interests in South Africa. Specifically, I stated that The New York Times shares directors with the boards of BristolMyers Co, Merck \& Co., and American Express. USA Today shares directors with the boards of Kellogg Company, McGrawHill Inc., and Standard Oil of Ohio. All of these companies have business interests in South Africa. They have a vested interest in seeing that U.S. foreign policies with South Africa protect those interests. 
The narratives of Mandela support and promote changes in South Africa which will allow for the lifting of economic sanctions. Journalists, through the use of pseudo-events, predict a future in which U.S. businesses will soon be able to return to South Africa and reap the economic benefits resulting from the lifting of those sanctions.

\section{SUGGESTIONS FOR FURTHER STUDY}

The situation in South Africa with its key figures (Mandela and de Klerk) provides the student of communication with a wealth of material for study. The "mainstream U.S. print media" used in this study has a reputation for being conservative. Additional insight into the creation and promotion of public heroes may be discovered by doing a comparison study of conservative and liberal media. Are the cultural myths and values espoused in the liberal media similar to those found in conservative sources?

Additionally, an examination of U.S. magazine coverage of Mandela may prove interesting and shed more light on the creation of his public persona since magazines generally go into more detail. Comparing and contrasting new reports and magazine articles may also reveal any inconsistencies in information made available to the public. Inconsistencies and variations in the treatment of Mandela's story may also be discovered by examining the reports found in international newspapers. Moreover, it may be possible to 
determine the reliability of the media's (along with magazines' and television's) portrayals of Mandela by examining Mandela' speeches with a focus on his philosophical and ideological orientations.

This thesis has implications for further research in the area of policy analysis. Specifically, attention should be given to institutional policies which shape the content and form of news reports. Analysis of these policies should lead to a more complete understanding of media motives. For example, peace in South Africa would create a climate conducive to economic prosperity for U.S. and international investors. What role does media policy play in creating such a climate and how does the media benefit?

The impact of news reports on audience perceptions can be examined via descriptive research techniques. Audience analysis is needed to fully evaluate the effects of media reports readers perceptions of Nelson Mandela and South Africa. Audience analysis is also needed to verify the exact nature of those perceptions.

Hopefully these suggestions will attract the attention of readers who are interested in the country of South Africa and its people, the creation of public heroes and celebrities, and the media's role in shaping public perceptions and social change. 
REFERENCES

African explains role in sabotage. (1964, April 21). The New York Times, p. A12.

Altschull, J. H. (1984). Agents of power. New York: Longman.

Aristotle. (1954). The rhetoric and the poetics of Aristotle (W. R. Roberts and I. Bywater, Trans.). New York: Random House.

Around the world, praise and celebrations. (1990, February 12). The New York Times, p. Al6.

Associated Press. (1993, July 3). S. African leaders haggle over remaining sanctions. Statesman Journal, p. A3.

Bagdikian, B. H. (1987). The media monopoly. Boston: Beacon Press.

Battersby, J. D. (1989, April 8). Mandela pleads for black unity. The New York Times, p. A3.

Battersby, J. D. (1988, February 25). South Africa bans most anti-apartheid activities. The New York Times, pp. A1, 10 .

Battersby, J. D. (1987, November 8). A free Mandela could aid peace, nationalist tells South Africans. The New York Times, p. A26.

Bennett, W. L. (1983). News: The politics of illusion. White Plains, NY: Longman.

Bennett, W. L. (1980). Myth, ritual, and political control. Journal of Communication, 30, 166-179.

Benson, M. (1986). Nelson Mandela: The man and the movement. New York: $W$. W. Norton.

Bird, S. E., \& Dardenne, R. W. (1988). Myth, chronicle, and story. In J.W. Carey (Ed.), Media, myths, and narratives: Television and the press (pp. 67-86). Newbury Park: Sage. 
Black leaders to be released in South Africa. (1989, October 11). The New York Times, pp. A1, 11).

Blanpied, N. A. (Ed.). (1986). Historic documents of 1985 . Washington, DC: Congressional Quarterly.

Boorstin, D. J. (1961). The image: A guide to pseudoevents in America. New York: Atheneum.

Bormann, E. G. (1985). Symbolic convergence theory: A communication formulation. Journal of Communication, 35, $128-138$.

Bormann, E. G. (1972). Fantasy and rhetorical vision: the rhetorical criticism of social reality. The Quarterly Journal of Speech, 58, 396-407.

Botha says he is seeking a way to permit the release of Mandela. (1988, August, 19). The New York Times, p. A11.

Boyden, D. P. (Ed.) . (1989). Gale directory of publications. Detroit: Gale Research.

Breen, M., \& Corcoran, F. (1986). Myth, drama, fantasy theme, and ideology in mass media studies. In B. Dervin \& M. J. Voigt (Eds.), Progress in Communication Sciences, I, (pp. 195-221). Norwood: ABLEX.

Broadcast in South Africa. (1990, February 12). The New York Times, p. 15 .

Brock, B. L., Scott, R. L., and Chesebro, J. W. (Eds.), (1990). Methods of rhetorical criticism. Detroit: Wayne state University Press.

Burke, K. B. (1962). A grammar of motives. Berkeley: University of California Press.

Burke, K. B. (1969). A rhetoric of motives. New York: George Braziller, Inc.

Burns, J. F. (1990a, February 12). On Mandela's walk, hope, and violence. The New York Times, pp. Al, 14.

Burns, J. F. (1990b, February 11). Mandela to go free today; De Klerk proclaims ending of "Chapter" after 27 years. The New York Times, pp. Al, 16. 
Burns, J.F. (1990c, January 30). Mandela, "Faceless man with a fax," negotiates his and his nations future. The New York Times, p. A3.

Burns, J. F. (1990d, January 26). Mandela appeal calls on Pretoria for negotiations. The New York Times, pp. Al, 6 .

Burns, J. F. (1990e, January 21). The A.N.C. is torn between generations. The New York Times, p. E3.

Burns, J. F. (1980, May 21). South African drive seeks freedom for key black leader. The New York Times, p. A2 .

Burns, J. F. (1978, July 19). Key black leader turns 60 on South African prison isle. The New York Times, p. A2.

Burns, J. F. (1977a, September 25). S. Africa has definite limits on its black consciousness. The New York Times, p. A3.

Burns, J. F. (1977b, June 4). "First lady" of black South Africans talks about curbs on her freedom. The New York Times, $\mathrm{pp} . \mathrm{A} 1,4$.

City College picks Mandela. (1983, March 22). The New York Times, p. A8.

Clines, F. X. (1988, June 11). BBC to mute Apartheid at a concert. The New York Times, p. 54.

Cohen, B. C. (1963). The press and foreign policy. Westport: Greenwood Press.

Corry, J. (1986, July 1). "Mandela," Documentary. The New York Times, p. C18.

Cowell, A. (1986a, February 1). Pretoria links Mandela's fate to Soviet dissidents. The New York Times, p. A4.

Cowell, A. (1986b, January 8). Americans barred from seeing Mandela. The New York Times, p. A3.

Cowell, A. (1985a, January 26). Pretoria promises city blacks 'a say'. The New York Times, p. A2.

Cowell, A. (1985b, July 7). The man nobody knows. The New York Times, p. F22. 
Cowell, A. (1984, October 17). Advocate of change. The New York Times, p. A5.

Dash, S. (1985, July 7). A rare talk with Nelson Mandela. The New York Times, pp. F21-22.

Doty, W. G. (1986). Mythography: The study of myths and rituals. University, AL: University of Alabama Press.

Epstein, E. J. (1973). News from nowhere. New York: Random House.

Excerpts from essay by Mandela for Botha. (1990, January 26). The New York Times, p. A6.

Farber, S. (1987, September, 19). Bringing 'Mandela' to television. The New York Times, p. 54.

Farnsworth, C. H. (1990, February 11). Bush calls release a bold and significant step. The New York Times, p. L17.

Feder, B. J. (1984, October 17). South African foe of apartheid wins 1984 Nobel Peace Prize: Leader of church council. The New York Times, pp. A1, 15.

Fein, E. B. (1984, October 17). South African foe of apartheid wins 1984 Nobel Peace Prize: Bells peal on 9th avenue. The New York Times, pp. A1, 15.

Fisher, W. R. (1989). Clarifying the narrative paradigm. Communication Monographs, $\underline{56}, 55-58$.

Fisher, W. R. (1987). Human communication as narration: Toward a philosophy of reason, value, and action. Columbia: University of South Carolina Press.

Fisher, W. R. (1984). Narration as a human communication paradigm: The case of public moral argument. Communication Monographs, 51, 1-22.

Fisher, W. R. (1973). Reaffirmation and subversion of the American dream. Quarterly Journal of Speech, 59, 347-367.

Fisher, W. R. (1970). A motive view of communication. Quarterly Journal of Speech, 56, 131-139.

Foss, S. K. (1989). Rhetorical criticism: Exploration and practice. Prospect Heights: Waveland. 
Foss, S. K., Foss, K. A., and Trapp, R. (1985). Contemporary perspectives on rhetoric. Prospect Heights: Waveland Press.

Four die in political hostage-taking in South Africa (1980, January 26). The New York Times, pp. A1, 7 .

Four dissidents abroad named by winner to share award. (1976, October 15). The New York Times, p. A28.

Fuchsberg, G. (1990, March 13). Will U.S. promoters give Mandela time to fight apartheid? The Wall Street Journal, pp. A1, 7 .

Fuerbringer, J. (1985a, September 12). Bid to tougher Pretoria curbs fails in senate. The New York Times, pp. A1, 8 .

Fuerbringer, J. (1985b, July 12). Senate approves economic moves against $\mathrm{S}$. Africa. The New York Times, pp. A1, 6 .

Gans, H. J. (1979a). Deciding what's news. New York: Vintage.

Gans, H. J. (1979b). The messages behind the news. Columbia Journalism Review, January/February, 40-45.

Gerard, J. (1988, June 13). In "South Africa now," daily life under apartheid. The New York Times, p. C18.

Gimlin, H. (Ed.). (1990). Historic documents of 1989. Washington, DC: Congressional Quarterly.

Gitlin, T. (1980). The whole world is watching: mass media in the making \& unmaking of the new left. Berkeley: University of California Press.

Golden, J. L., Berqquist, G. F., \& Coleman, W. E. (Eds.) (1989). The rhetoric of western thought. Dubuque: Kendall/Hunt.

Graber, D. A. (1984). Mass media and American politics. Washington D.C.: CQ Press.

Greenberger, R. S. (1990, February 13). Bush says South Africa sanctions stand, retreating from last week's remarks. The Wall Street Journal, p. A16.

Gronbeck, B. E. (1980). Dramaturgical theory and criticism: The state of the art (or science?). The Western Journal of Speech Communication, 44, 315-330. 
Guralnik, D. B. (Ed.). (1983). Webster's new world

dictionary, New York: Warner.

Gwertzman, B. (1985a, October 4). Shultz suggests that South Africa release Mandela. The New York Times, pp. Al, 10 .

Gwertzman, B. (1985b, september 10). Reagan in reversal orders sanctions on South Africa; Move causes split in Senate: New policy on Pretoria. The New York Times, pp. Al, 11 .

Kendall, F. (1990, February 12). Reading Mandela's mind. The Wall Street Journal, p. 14.

Kifner, J. (1990, June 20). Mandela to get New Yorkstyle greeting. The New York Times, p. A16.

Kraft, S. (1990a, February 11). S. Africa to free black leader Mandela today. The Los Angeles Times, pp. Al, 14,21 .

Kraft, S. (1990b, February 11). Mandela termed a Moses among blacks. The Los Angeles Times, p. A14.

Kraft, S. \& Cart, J. (1990, February 16). Whites march, decry freedom for Mandela. The Los Angeles Times, pp. A1, 11 .

Lacayo, R. (1990, July 2). A hero's welcome. The New York Times, pp. A14-20.

Larson, C. U. (1989). Persuasion reception and responsibility. Belmont: Wadsworth.

Lashgari, M.K., \& Gant, D. R. (1989). Social investing: The Sullivan principles. View of Social Economy, 47, 74-83.

Lawrence, J. S. \& Timberg, B. (1979). News and mythic Selectivity: Mayaguez, Entebbe, Magadishu. Journal of American Culture, 22, 321-330.

Lelyveld, J. (1986a, May 3). Pretoria gives signal on talks on rebels. The New York Times, p. A3.

Lelyveld, J. (1986b, March 18). Envoys break new ground in Mandela visit. The New York Times, p. A11.

Lelyveld, J. (1983, June 30). Pretoria extends ban on Mrs. Mandela. The New York Times, p. A3. 
Lelyveld, J. (1982, January 7). South African woman "banned" but unbowed. The New York Times, p. A4.

Lelyveld, J. (1981, March 17). Banished in South Africa, she vows to overcome. The New York Times, p. A2.

Lewis, A. (1989, February 5). Now why not talk? The New York Times, p. E25.

Lewis, W. F. (1987). Telling America's story: Narrative form and the Reagan presidency. Quarterly Journal of Speech, 73, 280-302.

Ling, D. A. (1970). A pentadic analysis of Senator Edward Kennedy's address to the people of Massachusetts July 25, 1969. Central States Speech Journal, 21, 81-86.

Littlejohn, S. W. (1989). Theories of human communication (3rd ed.). Belmont, CA: Wadsworth.

Lucaites, J. L., \& Condit, C. M. (1985). Re-constructing narrative theory: A functional perspective. Journal of Communication, Autumn, 90-108.

Lustig, M. W. (1988). Value differences in intercultural communication. In L. A. Samovar \& R. E. Porter (Eds.), Intercultural communication: A reader (pp. 55-61). Belmont: Wadsworth.

Lyall, S. (1990, February 12). Freedom for South African releases joy in New York. The New York Times, p. A17.

Mandela advised to have surgery. (1985, September 12). The New York Times, p. A8.

Mandela is transferred to a mainland jail. (1982, April 8). The New York Times, p. A5.

Mandela unbound. (1990, February 13). The Wall street Journal, p. A20.

Mandela wife sentenced. (1971, March 4). The New York Times, p. A19.

Mandela's cry of freedom. (1990, February 12). The New York Times, p. B6.

McFadden, R. D. (1990, February 12). Nelson Mandela. The New York Times, p. A16. 
McGovern, C. (Ed.). (1988). Historic documents of 1987. Washington, DC: Congressional Quarterly.

McGovern, C. (Ed.) (1987). Historic documents of 1986. Washington, DC: Congressional Quarterly.

Meer, Fatima (1988). Higher than hope. New York: Harper \& Row.

Moritz, C. (Ed.). (1990). Current biography. New York:

H. W. Wilson Company.

Moritz, C. (Ed.). (1984). Current biography. New York:

H. W. Wilson Company.

Mrs. Mandela in custody; Faces South African trial. (1967, April 9). The New York Times, p. 92.

The New Lexicon Webster's Dictionary of the English Language. (1987). New York: Lexicon Publications, Inc.

The New York Times Index. (1964-1985). New York: The New York Times Company.

Nimmo, D. and Combs, J. E. (1982). Fantasies and melodramas in television network news: The case of three mile island. Western Journal of Speech Communication, 46 , $45-55$.

Parenti, M. (1993). Inventing reality: The politics of news media. New York: St Martins Press.

Peterson, R. W. (Ed.). (1971). South Africa \& apartheid. New York: Facts on File.

Reich, R. (1987). Tales of a new America. New York: Times Books.

Robertson, J. O. (1980). American myth, American reality. New York: Hill \& Wang.

Rohter, L. (1985, April 25). Activism at schools seems to be stirring as protests continue. The New York Times, pp. A1, 20 .

Rotberg, R. I. (1989, August 3). South Africa's tide shifts. The New York Times, p. A23.

Rowland, R. C. (1990a). On mythic criticism. Communication Studies, $41,101-116$. 
Rowland, R. C. (1990b). On a limited approach to mythic criticism. Communication Studies, 41, 150-160.

Rule, S. (1985, September 12). Citizenship plan offered by Botha. The New York Times, pp. A1, 8 .

Rushing, J. H. (1986). Mythic evolution of "the new frontier" in mass mediated rhetoric. Critical studies in Mass Communication, $\underline{3}$, 265-296.

Rushing, J. H., \& Frentz, T. S. (1991). Integrating ideology and archetype in rhetorical criticism. Quarterly Journal of Speech, 77, 385-406.

Schudson, M. (1982). The politics of narrative form: The emergence of news conventions in print and television. Daedalus, 111(4), 97-112.

Scott, R. L. (1984). Narrative theory and communication research. Quarterly Journal of Speech, 79, 197-204.

Severin, W. J. (1988). Communication theories (2nd ed.). New York: Longman.

Sillars, M. O. (1991). Messages, meanings, and culture: Approaches to communication criticism. New York: HarperCollins.

Smith, C. (1990, February 4). As freedom nears, whites mythicize Mandela's role. The Los Angeles Times, p. M2.

Smith, R. R. (1979). Mythic elements in television news. Journal of Communication, 29, 75-82.

South Africa's new era: Looking back at Mandela and de Klerk. (1990, February 11). The New York Times, p. A18.

South African drops trial of 22 blacks and rearrests them under another act. (1970, February 17). The New York Times, p. A4.

South African Petrel. (1964, April 12). The New York Times, p. A12.

Sperry, S. L. (1981). Television news as narrative. In R. P. Adler (Ed.). Understanding television (pp. 295312). New York: Praeger.

Tatum, L. (Ed.) . (1987). South Africa: Challenge and hope. New York: Hill and Wang. 
Thurow, R. (1990a, June 19). Violent stirrings: Reform in South Africa has rightists talking of armed resistance. The Wall Street Journal, pp. A1, 17.

Thurow, R. (1990b, June 19). Mandela legend grows to superhuman proportions. The Wall street Journal, p. A17.

Thurow, R. (1990c, April 9). Nelson Mandela is walking a thin line between Pretoria and Black community. The Wall Street Journal, p. A9.

Thurow, R. (1990d, February 13). Mandela says negotiations may begin soon. The Wall street Journal, p. A16.

Thurow, R. (1990e, February 12). Time of trial: As Mandela goes free South Africa enters era of great moment. The Wall street Journal, pp. Al, 7 .

Thurow, R. (1990f, February 5,). Act of exorcism: Pretoria tries to ease its isolation by ending ban on black groups. The Wall street Journal, pp. A1, 4 .

Thurow, R. (1990g, January 26). Hopes for Mandela buoy Pretoria business. The Wall street Journal, p. A12 .

Thurow, R. (1989a, July 13). Mandela says "only way" to peace in South Africa is by negotiation. The Wall Street Journal, p. A10.

Thurow, R. (1989b, July 13). Is Nelson Mandela Pretoria's prisoner? Or is the white government his captive? The Wall Street Journal, p. Al6.

Transcript of Mandela's speech at Cape Town. (1990, February 12). The New York Times, p. A15.

Tuchman, G. (1978). Making news: A study in the construction of reality. New York: Free Press.

Ungar, S. J. (1990, June 17). Hero's welcome for a man U.S. betrayed: Mandela come to America. The Los Angeles Times, pp. M1, 5 .

The Wall Street Journal Index. (1964-1990). New York: Dow Jones \& Company, Inc.

Washington wire. (1990a, February 26). The Wall street Journal, p. Al.

Washington wire. (1990b, February 16). The Wall street Journal, p. Al. 
Washington wire. (1989, December 14). The Wall street Journal, p. P1.

Weaver, P. (1976, August 29). Captains of melodrama. The New York Times Magazine, pp. 6, 48, 50, 51, 54, 56,57 .

Weinraub, B. (1985, September 10). Reagan in reversal orders sanctions on South Africa; Move causes split in Senate: An executive act. The New York Times, pp. A1, 12.

Welleck, R. \& Warren, A. (1970). Theory of literature. New York: Harcourt, Brace \& World.

What Mandela wants: Statements at his '64 trial. (1990, February, 11). The New York Times, p. L18.

White, H. (1981). The value of narrativity in the representation of reality. In $\mathrm{W}$. J. T. Mitchell (Ed.), on narrative (pp. 1-23) Chicago: University of Chicago Press.

Wilkinson, T. \& Ford, A. (1990, June 30). Mandela gets star's welcome. The New York Times, pp. Al, 36.

Wren, C. S. (1990a, June 20). Mandela the messenger: Celebrated, yet life-size. The New York Times, pp. A1, 16.

Wren, C. S. (1990b, February 12). Speech is resolute. The New York Times, p. A1.

Wren, C. S. (1990C, February 11). The road from apartheid leads De Klerk and Mandela together. The New York Times, p. L18.

Wren, C. S. (1989a, December 14). De Klerk and Mandela discuss future. The New York Times, p. A3.

Wren, C. S. (1989b, October 16). Freed prisoners call on Pretoria to let Mandela go. The New York Times, pp. $\mathrm{A} 1,8$.

Wren, C. S. (1989C, July 14). A cup of tea for Mandela: Is the overture sincere or is it merely politics? The New York Times, p. A3.

Wren, C. S. (1989d, July 11). Pretoria's ruling party keeps silent on Mandela. The New York Times, p. A3. 
Wren, C. S. (1989e, July 9). Pretoria leader and Mandela meet in hint of release. The New York Times, Pp. A1, 10.

Yes to Mandela's Way. (1989, January 27). The New York Times, p. 26. 